University of Zurich

Department of Economics

Working Paper Series

ISSN 1664-7041 (print)

ISSN 1664-705X (online)

Working Paper No. 197

\title{
The Economics of Television and Online Video Markets
}

Gregory S. Crawford

June 2015 


\title{
The Economics of Television and Online Video Markets*
}

\author{
Gregory S. Crawford ${ }^{\dagger}$
}

June 17, 2015

\author{
"The need for images is universal." \\ Ernst Gombrich (1990), reviewing David Freedberg (1990), The Power of Images
}

"Television: A medium - so called because it is neither rare nor well done."

Ernie Kovacs (1950s), comedian

\begin{abstract}
Television is the dominant entertainment medium for hundreds of millions. This chapter surveys the economic forces that determine the production and consumption of this content. It presents recent trends in television and online video markets, both in the US and internationally, and describes the state of theoretical and empirical research on these industries. A number of distinct themes emerge, including the growing importance of the pay-television sector, the role played by content providers (channels), distributors, and negotiations between them in determining market outcomes, and concerns about the effects of market power throughout this vertical structure. It also covers important but unsettled topics including the purpose for and effects of both the old (Public Service Broadcasters) and the new (online video markets). Open theoretical and empirical research questions are highlighted throughout.
\end{abstract}

JEL: L82, L86, L32, M37, C72, D40, L40, L50

Keywords: economics, television, online video, public service broadcasting, advertising, pay television, bundling, bargaining, market power, net neutrality, foreclosure, policy

${ }^{*}$ This paper was prepared to be chapter 7 in Anderson, Waldfogel, and Stromberg, eds., Handbook of Media Economics, vol. 1A, Elsevier. I would like to thank Simon Anderson, Joel Waldfogel, Ali Yurukoglu, and especially Mark Armstrong for helpful comments. The material in Sections 3.1 4.1, and 4.4 were developed with the help of the latter's significant input.

${ }^{\dagger}$ University of Zürich, CEPR, and CAGE, gregory.crawford@econ.uzh.ch. 


\section{Introduction}

Television is special. It is special in its dominance of our leisure time 1 It is special in its impact on political participation, political debate, and political power ${ }^{2}$ It is special in its impact on preferences, beliefs, and culture $3^{3}$ Television influences many aspects of life in ways other products, even other media products, do not.

The goal of this chapter is to survey the economics of television and online video markets. Of course this focus on economics means I will cover only one narrow part of the impact television has on individuals, firms, governments, and society. Entire books have been written in fields as diverse as economics, marketing, and public policy; political science; media and communications studies; and art and art history analyzing the impact television has on contemporary life. The purpose here is to explain the mechanisms generating the programming and advertising which are the primary outputs of television markets, mechanisms that I believe are essential for understanding televisions potential impact in these other domains.

I therefore survey the demand and supply of television and online video markets. My scope is both theoretical and empirical, with an eye on those economic issues that have attracted the most attention of academics, regulators, and policymakers. In Section 2, I introduce the two main types of television commonly available to households (free and pay), describe the vertical supply structure that delivers television programming (content providers/channels and distributors/systems), and present those facts that best help understand the current functioning of the industry 4 In Section 3 , I introduce a simple model of two-sided television markets and assess the implications of this theory. In section 4, I describe the extensions to this simple model academics and policymakers have used to understand specific features of television markets. I call these extensions "The Four Bs": (Public Service) Broadcasters, Barriers to Entry, Bargaining, and Bundling. In section 5. I survey the highest-profile current open policy issues in television markets. In Section 6, I present patterns of online video use and discuss related policy issues at the intersection of television and online video markets. Section 7 concludes and provides directions for future research.

While the economics of television markets are largely common across countries, the quality of data available to study the U.S. market has made academic research more common there. This survey reflects this con-

\footnotetext{
${ }^{1}$ ([zzz Wilbur Chapter zzz]).

${ }^{2}$ e.g., Gentzkow (2006), Prat and Strömberg (2011)

${ }^{3}$ e.g., Gentzkow and Shapiro (2007), Jensen and Oster (2009).

${ }^{4}$ For most of the television industry's history, the typical distinction drawn in both the institutional and academic literatures has been between broadcast and pay television. The simultaneous development and diffusion of encryption technologies and multichannel (pay) digital broadcast distribution of television has weakened this distinction. I therefore choose to organize the chapter around the distinction between free and pay television, with the imperfect but still useful link between free television and broadcast television implicitly understood.
} 
straint, with the exception of my discussion of PSBs (an issue more relevant outside than inside the US) and mergers (where both US and European varieties have been important). Other chapters in this volume also cover more thoroughly topics that could sensibly have been included in my mandate. Anderson and Waldfogel ([zzz Anderson and Waldfogel chap zzz]) introduce the economic characteristics common to all media products - high fixed costs, heterogeneous preferences, and advertiser support - and these characteristics also influence outcomes in television markets. Anderson and Jullien ([zzz Anderson and Jullien chap zzz]) cover the theory of two-sided markets in more detail. The implications of Net Neutrality for the delivery of online video is also covered in the chapter by Peitz and Reisinger ([zzz Peitz and Reisinger chap zzz]). I discuss the economic issues at the heart of recent (mostly American) media mergers, complementing Foros, Kind, and Sorgard's largely European focus ([zzz Foros, Kind, and Sorgard chap zzz]). Wilbur discusses recent developments in mass media, including digitization and screen proliferation, two topics that are directly impacting television markets ([zzz Wilbur chap zzz]). The chapters by (zzz Gentzkow et al chap zzz) and (zzz Puglisi and Snyder zzz) summarize the theory and measurement of media bias. Early empirical applications were in newspaper markets, but the concerns apply equally well to television 5 Finally, a burgeoning literature in political science and economics is analyzing both the effects of governments on television and the effects of television on economic and social outcomes, including the election and activities of governments. The chapters by Prat ([zzz Prat chap zzz]) and Enikolopov and Petrova ([zzz EP chap zzz]) survey these topics in depth.

\section{The Television Industry}

\subsection{The Types of Television}

\subsubsection{Broadcast (Free) Television}

"Broadcasting" conventionally covers the distribution of both radio and television signals via electromag-

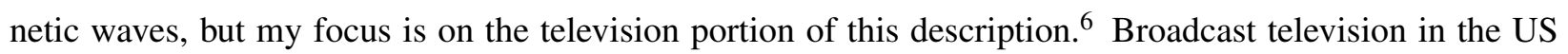
began in the 1930s, but gained widespread popularity and household penetration in the 1950s.7 While the specifics vary across countries, diffusion in Western Europe followed a similar pattern, with Africa and parts of Asia starting roughly ten years later. Television stations are generally licensed by a national regulatory authority, because the electromagnetic spectrum used by broadcasters is a national resource and licensing

\footnotetext{
${ }^{5}$ See, e.g., Martin and Yurukoglu (2014)).

${ }^{6}$ See ([zzz Sweeting chap zzz]) in this Handbook for a discussion of the broadcast radio industry.

${ }^{7}$ Gentzkow (2006) provides a concise survey of the early evolution of the US broadcast television industry.
} 
is required to prevent interference among broadcasters. In the US, broadcast stations are licensed by the Federal Communications Commission (FCC).

There are a wide variety of station types in the US (with similar patterns internationally), but the most important distinctions are between commercial and non-commercial stations, full- and low-power stations, and analog and digital stations. The vast majority of commercial stations support themselves through the sale of advertising, while non-commercial stations rely on donations from viewers or similar sources of funding other than advertising (FCC (2008)) ${ }^{8}$ The number of broadcast TV stations in the US has been stable over time at roughly 1,400 full-power stations, 28 per state and just under 7 per TV market (FCC (2013a)).

Low-power stations are smaller, local, and are often community-oriented. They are considered a secondary service and are not permitted to interfere with full-power broadcasters and are at risk of interference from them. Analog stations transmit programming using the continuous modulation of an uninterrupted sound wave, with different channels allocated to different portions of the electromagnetic spectrum, while digital signals digitally process and multiplex programming. Digital broadcasting is more efficient in its use of spectrum, freeing up spectrum previously used for analog broadcasting for other, higher-value uses.

In the US, there is often a separation of ownership between content providers (broadcast networks) and distributors (broadcast stations). Since the early days of the industry, the production of commercial broadcast programming has been organized and managed by "television networks," of which the largest are ABC, NBC, CBS, and FOX $9^{9}$ The left side of the left panel of Figure 1 shows the vertical structure associated with the broadcast television industry.

Table 1 reports aggregate statistics for US broadcast networks in 2012. Reported are measures of network costs (programming expenditure), quantity (viewership), price (advertising cost-per-thousand viewers, or CPM), and advertising revenue. I divide US broadcast networks into two groups: the so-called "Big-Four" broadcast networks mentioned above and "minor" broadcast networks. Broadcast networks only earn advertising revenue, with the Big Four receiving between $83-89 \%$ of the total broadcast viewing (ratings) and revenue.

In the US, FCC regulations limit the number of stations television networks can own; the remaining stations are owned by independent firms (that typically own many stations) that negotiate with television networks

\footnotetext{
${ }^{8}$ The US is an important exception. In the last 10 years in the US, broadcasters have successfully begun negotiating payments from pay television distributors under a regulatory rule called Retransmission Consent. Even so, commercial broadcasters in the US still earn the majority of their revenue from sales of advertising.

${ }^{9}$ See Owen and Wildman (1992, Chap. 5) for a valuable discussion of the economics of television networks.
} 
to be the exclusive provider of that network's programming in a TV market. TV markets are based on geography: The Nielsen Company has divided the US into 210 mutually exclusive and exhaustive markets called Designated Market Areas (DMAs) that are widely used in the sale of advertising. Most network programming is shown during "prime time" (7:00 p.m.-11:00 p.m.). News local to the station's principal community is produced by individual stations and programming in other parts of the day is either provided by the network or programmed independently with syndicators or independent program producers.

Public-Service Broadcasters In many countries, some portion of broadcast television service is provided by "public service broadcasters" (PSBs). PSBs compete with commercial broadcasters in providing content free over the air. In the US, "the mission of public broadcasting is to advance a well-educated, well-informed society capable of self-governing the world's greatest democracy." (CPB (2012)). In the UK, the mission of the BBC is famously to "inform, educate and entertain". In the broadest terms this captures the role of public service broadcasting in many countries; it is hard to come up with a more precise definition ${ }^{10}$ In practice, common aims of PSB policy are to ensure that diverse and high quality programming is supplied which caters to all interests and communities. In addition, programmes that yield educational and other social benefits are to be encouraged, including programmes that might make the population more tolerant, and also more aware of their regional and national identity. And in a related vein, there is often intervention to ensure that sufficient locally-produced content is available, and that the domestic "ecology" of programme production is protected 11 These values and examples of the types and providers of programming that support these values in the UK are shown in Figure $2{ }^{12}$

Funding for PSBs comes from a variety of sources that differ across countries and across PSBs within countries, including mandatory household license fees, sales of advertising, and/or donations from viewers. The right side of the left panel of Figure 1 shows the vertical structure and payment flows associated with PSBs. In the UK, the oldest and largest PSB, the British Broadcasting Corporation (BBC), is the beneficiary of an annual license fee of $£ 145.50$ (approx \$20/month) and sells no advertising, while the other commercial PSBs in the market - ITV, Channel 4, and Channel 5 - receive no license fee and only sell advertising. In the US,

\footnotetext{
${ }^{10}$ The UK's Peacock Committee, discussed in Section 4.1 below, noted it had experienced difficulty obtaining a definition even from the broadcasters themselves.

${ }^{11}$ The UK's 2003 Communications Act defined four basic objectives for PSBs: to promote social values, to offer high-quality programming, to provide range and balance in its programming, and to provide diversity of programming. Section 4.1 below discusses the rationale for and effects of PSBs in more detail.

${ }^{12}$ This figure is taken from Ofcom (2004). Similar social purposes are found in PSB systems of other countries. The PSB Charter for Ireland's Radio Telifis Éireann (RTÉ) includes among its guiding principles "the democratic, social and cultural values of Irish society". NZ On Air, the funding body for PSBs in New Zealand, states as its mission, "to reflect and foster the development of New Zealand culture and identity through broadcasting”.
} 
public service broadcasting is provided by public (non-commercial) television stations that provide a mix of locally- and nationally-produced programming. The majority of the national programming is provided by the Public Broadcasting Service (PBS), a non-profit public broadcaster jointly owned by over 350 member television stations. Funding for public broadcasting comes from a mix of sources, with contributions from individuals most important ( $22 \%$ on average across public television stations), followed by federal government support (18\%), state and local government support (17\%), university and foundation support (15\%), and underwriting by businesses (13\%) (CPB (2012)).

Figure 3 reports the aggregate amount of public (government) funding for television along with the perhousehold-per-month TV license paid for a selection of major world economies 13 It shows that most developed country governments provide between $\$ 6$ and $\$ 15$ per household per month in public support for television. The US, despite being the largest television market in the world, provides only $\$ 0.40$ per household per month in government support for PSBs.

\subsubsection{Pay Television}

Pay television is just that: television supported at least in part by payments from subscribers (households). The production of pay-television programming occurs as part of a vertical supply chain. Television channels contract with (often small) program producers for individual programs and form (often 24-hour) television schedules. They then license the right to perform these programs with cable, satellite, and telecommunications companies in what is called the programming market. In turn, these distributors aggregate channels into bundles and sell access to these bundles to households in what is called the distribution market. The right panel of Figure 1 shows the vertical structure and payment flows associated with pay television providers. Revenues in the pay television industry arise from a mix of subscriber and advertiser payments. Content providers (non-broadcast television channels) differ considerably in their revenue mix, but roughly $50 \%$ of upstream industry revenue comes from each source (SNL Kagan (2014a)). Distributors (cable, satellite, and IPTV providers) rely predominantly $(90+\%)$ on payments from subscribers.

Pay TV Distribution In the US, pay television arose in the form of "cable television.' 14 Cable TV began in the 1950s to transmit broadcast signals to areas that couldn't receive them due to interference from natural features of the local terrain (e.g. mountains). Cable systems needed access to public infrastructure and so typically reached exclusive franchise agreements with local governments granting this access

\footnotetext{
${ }^{13}$ See also Table 4

${ }^{14}$ The material discussed in this subsection is discussed in more detail in Crawford (2013).
} 
in return for price, quality, and/or service guarantees. FCC regulations initially limited the provision of additional, non-broadcast, programming, but these were relaxed in the late 1970s and, with the simultaneous development and regulatory liberalization of satellite technologies, numerous programming networks were launched, including some of the most recognizable TV brands in the world (e.g. CNN, ESPN). Between 1980 and 2000, the pay (cable) TV industry experienced phases of price regulation and deregulation, and grew considerably: 15

Entry into the pay television distribution market is a risky and expensive undertaking. Many thought cable distribution was a natural monopoly in the early years of the industry and cable operators consequently negotiated exclusive arrangements with franchise authorities 16 The 1992 Cable Act reversed this policy, outlawing exclusive franchises, but there was limited entry concentrated in big cities from so-called "cable overbuilders."

The year 2000 was an watershed in the development of the US pay television industry. Previous to that year, satellite companies were not permitted to distribute local broadcast signals by satellite, putting them at a competitive disadvantage relative to cable operators. The 1999 Satellite Home Viewer Improvement Act relaxed this restriction, permitting the so-called "local into local" carriage of local broadcast signals into local television markets. Cable subscribers peaked in 2000, despite continued annual industry subscriber growth, and are now $10 \%$ below that peak. Subscriptions to the two major national satellite providers have absorbed the majority of industry growth since that date.

The gradual convergence of television and communications (i.e. telephone) technologies in the last 20 years have given rise to entry by former telephone companies ("telcos") into video markets. Most such entrants provide service using Internet Protocal (IP) technologies rather than conventional dedicated coaxial cable or satellite broadcast technologies and are therefore called IP television (IPTV) providers. In the US, telco entry was permitted by the 1996 Telecommunications Act, but didn't happen on a large scale until the mid-2000s with major infrastructure investments by two of the three major telcos. Since then, these two operators have grown to serve $10 \%$ of the national market despite being available to less than two-thirds of US households. Figure 4 shows the pattern of subscribers to US pay television platforms from 1985-2013. Using data from FCC (2012a), Figure 5 reports an estimate of the distribution of US cable television prices across markets in 2011, measured as the average expenditure on Basic, Expanded Basic, and Digital Basic cable services $\sqrt{17}$ There is significant heterogeneity across cable systems in the price of Basic Services, with

\footnotetext{
${ }^{15}$ See Hazlett and Spitzer (1997) and Crawford (2013) for discussions of this period in the industry's regulatory history.

${ }^{16}$ The auctioning of cable franchises was thought to be one way of controlling cable system market power and was first suggested by Williamson (1976). Zupan (1989b) (Zupan (1989a)) evaluate the success of this strategy for initial franchise awards (renewals).

${ }^{17}$ These data were obtained from the FCC using a Freedom of Information request. They included information about the price
} 
an average of $\$ 6 7 . 6 4 \longdiv { 1 8 }$ Much of the heterogeneity in prices is likely driven by heterogeneity in the number of channels available to subscribers depicted in Figure 7 below.

A recurring concern in US pay television markets is the persistent increase in pay television prices over time. Figure 6/reports price indices from the Consumer Price Index (CPI) from December, 1983 until December, 2013. Reported are series for MVPD (i.e. cable + satellite) services and consumer non-durables. Pay television prices have grown by $5.1 \%$ annually, almost $2 \%$ per year faster than nondurable prices ${ }^{19}$ This price growth has prompted recurring concerns about market power in the industry, a topic I revisit in Section 4.3 below.

Pay TV Program Production (Channels, Networks) There are broadly three types of pay-television channels. Cable programming networks are fee- and advertising-supported general and special-interest networks distributed nationally to distributors via satellite. Examples from the US include some of the most recognizable networks associated with pay television, including MTV, CNN, and ESPN ${ }^{20}$ An important subset of cable networks from a policy perspective are Regional Sports Networks (RSNs). As per their definition, these are regional networks that carry live broadcasts of performances of sports teams that play in and belong to the areas served by the networks. Examples include Yankees Entertainment and Sports Network (YES), Comcast SportsNet Chicago, and the Big Ten Network. While the sports carried vary somewhat across networks, a typical RSN will show those games that aren't being carried on a national network from the US professional basketball (NBA), baseball (MLB) and hockey (NHL) leagues for the 1-2 franchises per sport in their service area 21 Premium programming networks are advertising-free entertainment networks, typically offering full-length feature films. Examples include equally familiar networks like HBO and Showtime.

As of the 2010s, US households have access to many pay-television channels. 2011 data from Nielsen's

for Basic, Expanded Basic, and the most popular Digital Basic service for a stratified random sample of cable systems in the US. See FCC (2012a, Para.8) for details of the sampling plan. The sample averages in the Price Survey weighted by subscriber. Because the data provided were stripped of system and geographic identifying information, I could not weight by subscribers. Following FCC (2012a), I calculate average expenditure as the price of Expanded Basic Service plus a weighted average of the price of Digital Basic Service, with the weight given by the share of Expanded Basic subscribers that took Digital Basic in 2011. From SNL Kagan (2014a), this figure was $79.4 \%$.

${ }^{18}$ See also Table 4

${ }^{19} \mathrm{~A}$ significant challenge when interpreting pay television price changes is accounting for differences in the quality of cable service. Crawford, Kwerel and Levy (2008) describes how the FCC, in FCC (2009), proposed using price-per-viewer-hour as a measure of quality-adjusted cable prices. It shows that between July 1997 and January 2008, price-per-viewing-hour of cable services increased by a CAGR of $5.8 \%, 2.8 \%$ more than the $3.1 \%$ CAGR in the nondurable CPI over the same period. Thus cable prices have also been rising on a quality-adjusted basis.

${ }^{20}$ So-called cable networks earned their name by having originally been available only on cable.

${ }^{21}$ The revenue these networks provide to individual sports teams are an increasingly important part of teams' businesses and an important driver of outcomes in sports markets. For example, TWC SportsNet Los Angeles recently agreed to pay the US Baseball team the Los Angeles Dodgers $\$ 8.35$ billion to carry the team over a 25 -year period. 
FOCUS database on the population of US cable television lineups indicates that there are 282 television networks available to at least $1 \%$ of US households. Figure 7 reports the distribution of channels offered on Basic, Expanded Basic, and Digital Basic cable service across the 6,000 systems offering service in 201122 The distribution is very left-skewed, with a (weighted) mean of just under 160 channels. Satellite and telco systems also offer hundreds of pay-television channels.

Tables 2 and 3 report aggregate statistics for the largest US pay-television networks for which data are available. Reported in each table are measures of network costs (programming expenditure), quantity (viewership and subscribers), price (advertising cost-per-thousand, or CPM, and affiliate fees, if any), and revenue, as well as the relative importance of advertising versus fee revenue in each channel's total. In Table 2, I report information for the top-25 most widely available cable networks, as well as totals for all 198 cable networks for which information is available from SNL Kagan ${ }^{23}$ In Table 3 , I report information for all 40 RSNs and all 8 premium networks 24

There is considerable heterogeneity across networks both within and across types. As suggested above, premium networks only earn affiliate fee revenue, and the remaining networks earn a mix of both, with the relative importance of each differing by channel. Overall, cable networks earn the majority of advertising, affiliate fee, and total revenue. The top- 25 cable networks by revenue receive approximately two-thirds of cable network advertising and affiliate fee revenue, despite accounting for less than half of cable network viewership and only 13\% (25 of 198) of the networks for which such data are available. Regional Sports Networks, while only relevant in those regions where they carry local sports content, are nonetheless very important in the industry, with total revenue rivalling national premium networks.

\subsubsection{Broadcast (Pay) Television: DTT}

In the mid-2000s, television regulators around the world began requiring broadcast stations to use digital instead of analog technologies 25 Such broadcasting is often called Digital Terrestrial Television (DTT). The Netherlands was the first country to switch, in 2006, and has since been followed by many more (ITU (2012)) ${ }^{26}$ While economically unimportant in the US, this transition led in many countries to the growth of

\footnotetext{
${ }^{22}$ To approximate the number of channels available to a household selected at random in the US, the data are weighted by the households served by each cable system.

${ }^{23}$ SNL Kagan, an industry resource, collects information on 198 cable networks, 40 RSNs, and 8 premium networks (in 4 corporate families). All of the summary statistics reported here rely on this subset of cable, RSN, and premium channels.

${ }^{24}$ For the former I group together the 13 Fox Sports, 8 Comcast SportsNet, and 3 Root Sports RSNs and report summary statistics for each of these families of RSNs.

${ }^{25}$ Transitioning between analog and digital broadcasting must happen simultaneously within broadcasters' transmission areas to avoid issues of interference, though it can be done either regionally (as in the UK) or nationally (as in most countries).

${ }^{26}$ The US made the switch by 2009, and the UK by 2012 .
} 
multi-channel digital broadcast offerings that are a credible substitute to pay television bundles offered via other technologies. In some countries, notably the UK with Freeview, until recently this offering relied solely on advertising revenues and was thus free to households, while in others, notably France with Télévision Numérique Terrestre, it was a mix of free and pay channels.

The relative importance of cable, satellite, and telcos (IPTV) as distributors of video programming varies considerably across the world due to the vagaries of the evolution of video markets across countries. Figure 8 reports the share of households that obtain video service by type of platform: (analog) broadcast, digital broadcast (DTT), cable, satellite, and telco (IPTV). The relative importance of each of the platforms shows significant heterogeneity. For example, less than $15 \%$ of households are served by cable in the UK and Brazil (and not at all in Italy), whereas almost $70 \%$ are served by cable in the Netherlands and Canada. In almost all countries, analog broadcast is free and cable, satellite, and telco provision is paid. DTT is sometimes free and sometimes paid (even within country); Figure 9 reports for the same countries the share of TV households served by free versus pay platforms. This varies widely, from between $70-80 \%$ in Spain and Brazil to less than $15 \%$ in the Netherlands, the USA, and India.

\subsection{Cross-Platform Television Statistics}

Table4 4 reports aggregate statistics about the television industry for a selection of countries in 2011. Reported is information about availability, access, use, and revenue by funding source. Information about subscribers by platform was already shown in Figure 8 . Average individual television viewing varies substantially across the listed countries, from a low of 2.0 hours for India to a high of 4.9 for the US ${ }^{27}$. Average price data isn't readily available, but a close relation, "average revenue per unit," measures the average expenditure on pay television by purchasing households. These were converted to US dollars using 2011 IMF exchange rates (Ofcom (2012)). These also vary widely, from a low of \$3-4 in India and Russia to a high of over \$83 in the US ${ }^{28}$ The US is also not surprisingly the world's largest television market, with annual aggregate revenue of $\$ 160.4$ billion or $\$ 112.73$ per household per month. Of this, almost two-thirds comes from subscriptions and a third from advertising, with a negligible share coming from public funding. The difference in perhousehold television industry revenues and the relative importance of alternative sources of funding also vary widely across countries. The reasons for this variation has to my knowledge not previously been analyzed in the academic literature.

\footnotetext{
${ }^{27}$ ([zzz Wilbur chap, Figure 2 zzz]) shows that in the US, watching TV takes up almost half of the time people spend using mass media, almost double the next closest medium (listening to AM/FM radio)

${ }^{28}$ This likely differs from the $\$ 67.64$ reported above as it includes expenditure on premium networks and ancillary fees.
} 
Figure 10 shows total TV revenue across time by groups of countries. The US accounts for over $40 \%$ of the estimated world television revenues of $\$ 400.5$ billion. Global television industry revenue has exhibited steady year-on-year increases, with significant growth coming from developing countries like the BRICs ${ }^{29}$ Figure 11 shows that in the US, as in many world markets, television advertising has not suffered from the recent growth in Internet use and advertising. As emphasized by [zzz Wilbur chap zzz], whether measured by time spent watching, subscription revenue, or advertising revenue, "television appears to be the most important mass medium" (Wilbur chap, p5).

Other patterns are evident from a closer look at US data. Figures 12 and 13 break out US programming market revenue by program type and revenue source across time. While broadcast network revenue has remained roughly constant across time, cable, RSN, and premium network revenue have all grown substantially. Advertising revenue has been the historical driver of programming market revenue, but was surpassed by affiliate fee revenue in 2010 .

What's driving this revenue growth and what are the consequences for the distribution market? Figure 14 shows that patterns of programming expenditure by channels matches that of revenue growth, while Figure 15 shows that this higher expenditure has enabled channels to negotiate ever-increasing affiliate fees from downstream distributors. Of particular note in Figure 15 is the recent growth in "Retransmission Consent" fees negotiated by broadcast networks from distributors for the right to distribute broadcast signals that are otherwise available free over the air 30 The contribution of retransmission consent fees has merely increased the already considerable growth in affiliate fees for cable networks. These, in turn, are important factors in the pattern of ever-increasing prices to households for pay-television service presented in Figure 6 above.

The overall growth in channel advertising revenue shown in Figure 13 hides an important compositional effect. While relative ratings for broadcast networks remain strong (e.g. compare Tables 1 and 2), Figure 16 shows that total household viewing on cable networks exceeded that on broadcast networks in the mid-2000s and has continued to grow, as of 2012 comprising $74.4 \%$ of household 24-hour viewing. All these patterns point to a large and growing importance of pay-television in the functioning of US television markets.

\footnotetext{
${ }^{29} \mathrm{BRIC}=$ Brazil, India, and China.

${ }^{30}$ This effect is not in Table 1 as these fees largely accrue to television stations and not to the television networks providing the majority of the programming on those stations. This is a source of dispute between broadcast networks and stations, however, as networks seek to share in these revenue streams.
} 


\section{A simple model of the television market}

As discussed in greater detail in Chapters [zzz Anderson-Jullien chap zzz], media markets are two-sided, providing both content to households in return for subscription fees and audiences to advertisers in return for advertising payments. This two-sided structure and the relative importance on these two funding sources has important implications for prices, ad levels, programming choices, quality, and welfare.

In this section, I present a stylized model of television program production and distribution ("broadcasting") which borrows elements from Armstrong and Vickers (2001), Anderson and Coate (2005), Armstrong (2005), Armstrong (2006), and Peitz and Valletti (2008). I use this model to derive testable implications about outcomes in television markets which are discussed later in the section. In the next section, I highlight the specific institutional features of television markets that have required extending this stylized model in four important directions ("The Four Bs").

\subsection{The baseline model}

\subsubsection{Baseline Results}

A broadcaster potentially makes decisions along a number of basic dimensions, including:

- the price (or more generally the tariff structure) for viewing its programmes;

- the advertising intensity within its programmes;

- the quality of its programmes, and

- the genre of its programmes.

Regulation, competitive conditions, and/or technological constraints may affect these decisions. For instance, traditional over-the-air broadcast technology does not allow viewers to be excluded from the signal, and so direct pricing of content may not be feasible. Regulations might constrain advertising intensity, or technology might allow viewers to skip advertisements. Public service broadcasters might face constraints on quality, genre, or the neutrality of news programmes. We address some of these factors in the presentation to come.

We assume that a monopoly broadcaster has a unit of content (e.g., a single channel, or a single programme) to supply to viewers. A viewer's gross value for this content is denoted $v$, and $v$ is distributed in the 
population of potential viewers in some manner. All viewers are homogeneous in terms of their attitude to advertising intensity, and if they pay $p$ for the content which has advertising intensity $a$, their "total price" is

$$
P=\delta a+p
$$

Viewers in most cases dislike intrusive advertising, and so we assume that $\delta \geq 0$. A viewer with valuation $v$ will then decide to watch this content when $v \geq P$, and we denote the number of viewers with $v \geq P$ by $x(P)$, the demand function for viewing.

Suppose that if the broadcaster shows $a$ ads it obtains revenue $r(a)$ per viewer from advertisers, which we suppose is a concave function. Total revenue per viewer is therefore

$$
R=p+r(a)
$$

The relationship between total revenue $R$ and total price $P$ will depend on whether a subscription charge $p$ can be used. If it can be used, then for any total price $P$, we have $P=\delta a+p$ and $R=p+R(a)$, so that $R=P+r(a)-\delta a$. The broadcaster will clearly choose advertising intensity $a^{*}$ to maximize revenue for any given total price $P$, so that

$$
a^{*} \text { maximizes } r(a)-\delta a \text {. }
$$

Note that $a^{*}$ is the advertising intensity which maximizes the joint surplus of the broadcaster and the viewer, and it ignores the surplus of advertisers themselves. We often expect advertiser surplus to increase with $a$, and in such cases the broadcaster chooses an inefficiently low level of advertising ${ }^{31}$ In some cases (when $r^{\prime}(0) \leq \delta$ ) the equilibrium level of advertising is zero, so that a viewer's disutility from adverting is greater even than the value to the most valuable advertiser ${ }^{32}$ Otherwise, though, viewers are prepared to tolerate some advertising in compensation for a lower direct charge. The relationship between total revenue and total price in the pay-TV regime is

$$
R_{\text {pay }}(P)=P+r\left(a^{*}\right)-\delta a^{*},
$$

and an extra dollar extracted from a viewer translates into exactly one extra dollar for the broadcaster.

\footnotetext{
${ }^{31}$ Suppose, as assumed by Anderson and Coate (2005) and Peitz and Valletti (2008), that each advertiser is a separate monopolist, and can extract all consumer surplus when it sells its product. In this case, aggregate advertiser surplus is captured by the area under their demand curve. This implies that the level of advertising which maximizes total welfare is such that the advertising price, $r(a) / a$, is equal to the disutility $\delta$. It follows that advertising is socially excessive [insufficient] if $r(a)-\delta a$ is negative [positive].

${ }^{32}$ This is presumably the reason why novels and live opera typically contain no ads.
} 
By contrast, in the free-to-air world with no direct viewing charge $(p \equiv 0)$ there is a concave relationship between total revenue and total price, given by

$$
R_{\text {free }}(P)=r(P / \delta)
$$

If regulation places a ceiling on advertising intensity, this corresponds to a cap on the total price $P$. The function $R_{\text {free }}$ equals $R_{\text {pay }}$ at one point (when $P=\delta a^{*}$, which implies that $p=0$ in the pay regime), but otherwise lies below $R_{\text {pay }}{ }^{33}$ The intuition for this is clear: in the pay-TV regime the broadcaster has two instruments to extract revenue from the viewer, while in the free-to-air regime it has only one, and so it can more efficiently extract revenue in the pay-TV regime.

If, as is highly plausible, charging a negative price to viewers (i.e., $p<0$ ) is not feasible, the analysis of the pay-TV regime sometimes needs modifying. When the chosen total price $P$ is below $\delta a^{*}$, the corresponding direct price $p$ is negative. Thus, when negative prices are not feasible, the revenue function continues to be given by (1) when $P \geq \delta a^{*}$, while for smaller $P$ the pay-TV regime involves a zero price, and the revenue function coincides with $R_{\text {free }}$ in 2 . When $P \geq \delta a^{*}$, the concavity of $r(\cdot)$ can be shown to imply that $R_{\text {pay }}(P) / R_{\text {free }}(P)$ increases with $P$, so that the pay-TV regime delivers proportionally higher revenue than the free-to-air regime, not just in absolute terms.

For simplicity, suppose that the broadcaster already possesses his content, and incurs no additional costs for distributing this content to viewers. It follows that the broadcaster's total profit is

$$
x(P) R(P),
$$

where $R$ is given by $R_{\text {pay }}$ or $R_{\text {free }}$ according to whether direct charging of viewers is feasible. Even when charging viewers is feasible, the broadcaster may choose to obtain its revenue solely from advertisers. (This is the case when the advertising intensity $a$ which maximizes profits in the free-to-air regime, $x(\delta a) r(a)$, is below $a^{*}$, the advertising level when the firm can charge a positive viewer price.) One can show the total price $P$ is weakly higher in the pay-TV regime than in the free-to-air regime, so that viewers are worse off in the pay-TV regime ${ }^{34}$ Likewise, there is weakly less advertising in the pay-TV regime than in the free-to-air regime, so that advertisers typically prefer the free-to-air regime 35 While there is too little advertising in

\footnotetext{
${ }^{33}$ This is because $R_{\text {pay }}(P)=P+r\left(a^{*}\right)-\delta a^{*} \geq P+r(P / \delta)-\delta(P / \delta)=R_{\text {free }}(P)$.

${ }^{34}$ Recall that if a negative price is not feasible, that $R_{\text {free }}=R_{\text {pay }}$ for all $P \leq \delta a^{*}$. If the best price in the free-to-air regime satisfies $P \leq \delta a^{*}$, it is clear that the best price in the pay-TV could not be lower than this. If the best price in the free-to-air regime is greater than $\delta a^{*}$, the fact that $R_{\text {pay }} / R_{\text {free }}$ increases with $P$ for $P \geq \delta a^{*}$ implies that the broadcaster is better off choosing a higher total price in the pay-TV regime.

${ }^{35}$ Either the total price is below $\delta a^{*}$ in both regimes or the total price above $\delta a^{*}$ in both regimes. In the former case, advertising levels are the same. In the latter case, advertising intensity is $a^{*}$ in the pay-TV regime and strictly higher in the free-to-air regime.
} 
the pay-TV regime, in the free-to-air regime whether equilibrium advertising is excessive or insufficient is ambiguous. Indeed, total welfare might be higher or lower in the pay-TV regime relative to the free-to-air regime 36

Since the broadcaster obtains greater profit when it can charge viewers, it may be that some content can be profitably supplied only if viewers can be charged. As a result, even if the use of viewer charges reduces consumer surplus for a given range of content, the fact that more content might be offered in a pay-TV regime could lead to consumer gains from the practice.

In his discussion of recent developments in mass media, ([zzz Wilbur chap zzz)] discusses the effects of adavoidance technology. We also analyze that issue here. In the pay-TV regime, the widespread introduction of ad-avoidance technology will usually harm consumers once the broadcaster's response is considered. Without the ad-avoidance technology, the broadcaster chooses total price to maximize $x(P)\left(P+r\left(a^{*}\right)-\right.$ $\left.\delta a^{*}\right)$, while with the technology it is in effect forced to set $a=0$ and it maximizes $x(P) P$, which induces a higher total price whenever $a^{*}>0$. Since a viewer dislikes advertising, it is a dominant strategy for her to avoid it when technology is available to permit this. But this behaviour involves a negative spillover onto other viewers, since the broadcaster can then obtain less revenue from advertisers, and this induces it to raise its direct price. Thus, in this simple framework, a prisoner's dilemma occurs with ad-avoidance, and all viewers would be better off if ad-avoidance were not feasible. Of course, in a purely advertising-funded regime, the adoption of ad-avoidance technology would be catastrophic for the market.

We next consider a number of natural extensions to this basic model.

\subsubsection{Oligopoly}

The basic model above considered a single broadcaster in isolation, taking rival offerings as exogenous. Additional issues arise when the impact of one broadcaster's choices on a rival is considered. To illustrate, suppose there are just two broadcasters, $A$ and $B$, and for the relevant time-slot suppose a viewer must watch the content of one or the other (or neither). If $P_{A}$ and $P_{B}$ are the total prices chosen by the respective broadcasters, suppose that $A$ gains $x_{A}\left(P_{A}, P_{B}\right)$ viewers, while $B$ attracts $x_{B}\left(P_{B}, P_{A}\right)$. Then, as in (3), given the rival total price $P_{j}$, broadcaster $i=A, B$ chooses its total price to maximize

$$
x_{i}\left(P_{i}, P_{j}\right) R\left(P_{i}\right)
$$

where $R$ is given by $R_{\text {pay }}$ or $R_{\text {free }}$ according to whether direct charging of viewers is feasible ${ }^{37}$ In the-

\footnotetext{
${ }^{36}$ See Anderson and Coate (2005) for further details.

${ }^{37}$ This presentation assumes that the competitive interaction is such that each broadcaster commits to provide a given quantity of
} 
oretical models of broadcasting, a popular specification for $x_{i}$ is the symmetric Hotelling demand system where

$$
x_{i}\left(P_{i}, P_{j}\right)=\frac{1}{2}-\frac{P_{i}-P_{j}}{2 t}
$$

where $t$ is the "transport cost" parameter which reflects how substitutable are the two firms' offerings. In this framework, note that total prices are strategic complements, and a broadcaster's best response to its rival's total price is an increasing function of that price. In particular, if there is asymmetric regulation applied to just one broadcaster in the form of a price cap (in the pay-TV regime) or a ceiling on advertising (in the free-to-air regime), this will cause a corresponding reduction in the unregulated rival's choice of price or advertising.

In this particular case, the symmetric equilibrium choice of price $P$ satisfies

$$
\frac{R^{\prime}(P)}{R(P)}=\frac{1}{t}
$$

In the pay-TV regime where $R$ is given by (1), it follows that the equilibrium charge to viewers is

$$
p=t-r\left(a^{*}\right)
$$

and this charge is positive provided that $t>r\left(a^{*}\right)$. In the free-to-air regime the equilibrium advertising intensity satisfies

$$
\frac{r^{\prime}(a)}{r(a)}=\frac{\delta}{t}
$$

Since we know that $R_{\text {pay }} / R_{\text {free }}$ increases with $P$, it follows that $R_{\text {pay }}^{\prime} / R_{\text {pay }} \geq R_{\text {free }}^{\prime} / R_{\text {free }}$, and so (4) implies that the total price paid by viewers is higher in the pay-TV regime than in the free-to-air regime, so that viewers in this model are better off in the ad-funded regime ${ }^{38}$ In addition, the concavity of $r(\cdot)$ implies that equilibrium advertising intensity is greater in the free-to-air regime than in the pay-TV regime.

\subsubsection{Content choice}

The main cause of market failure in the analogue era was due to advertising being the sole commercial source of funds. The basic problem with advertising-funded television is that whether or not a programme is profitable need not depend closely upon how strongly viewers like the programme. If a cheap quiz show advertising. If instead the competition is in terms of prices on the advertising side, a complicated feedback can occur in the market, as discussed in Armstrong (2006).

${ }^{38}$ From [5, if $r\left(a^{*}\right) \geq t$ then firms in equilibrium do not charge viewers directly, and the outcome is the same as the free-to-air regime. 
would draw the same audience as an expensive drama, then there would be no point for an advertisingfunded broadcaster to spend extra resources on the latter. Similarly, programmes that appeal strongly to a relatively narrow audience would not be produced, even though they might generate substantial social surplus.

Moving to a subscription television system, however, greatly mitigates this problem. Since the broadcaster can extract viewers' surplus directly, we expect that it will have an incentive to show a diverse selection of programmes of quality appropriate to viewers' willingness-to-pay. For instance, drama series might be unprofitable for an advertising-funded broadcaster, but not for a subscription broadcaster which can extract viewers' higher willingness-to-pay for this genre compared to soaps, say.

To illustrate this, suppose for simplicity that viewers suffer no disutility from advertising (so $\delta=0$ ) and the broadcaster can obtain maximum revenue $r$ per-viewer from advertisers ${ }^{39}$ There are a number of programme options available, labelled $i$, which vary in audience size $n$ and the willingness-to-pay $v$ of that audience. (Thus, each option has rectangular demand, with inelastic demand $n$ so long as price is below $v$.) Programme option $i$ has audience $n_{i}$, reservation price $v_{i}$ and fixed cost $F_{i}$. If the broadcaster must choose just one of these options, then without the ability to charge for content, the broadcaster will choose the content with the highest value of

$$
n_{i} r-F_{i} .
$$

However, if it can charge for viewing, it will charge viewers their reservation price and so choose the content which maximizes

$$
n_{i}\left(r+v_{i}\right)-F_{i}
$$

Since the latter choice takes into account viewer surplus, it is likely to be better aligned with total welfare (although viewers are left with no surplus). If there is a programme type ("lowest common denominator" content) which is just better than nothing for most people and which costs little to produce (i.e., $n_{i}$ is large, while $v_{i}$ and $F_{i}$ are small), this will be offered by the broadcaster in the free-to-air regime, but some other content would likely be offered in the pay-TV regime.

This discussion can be applied to the particular case of programme quality ${ }^{40}$ Suppose that the broadcaster can choose quality, and making (or otherwise sourcing) programmes with quality $q$ requires a fixed cost $C(q)$. Suppose that viewer demand for content with quality $q$ and total viewing price $P$ is $x(P \mid q)$, where

\footnotetext{
${ }^{39}$ See also ([zzz Anderson and Waldfogel chap zzz]) and ([zzz Foros et al chap zzz]) for further discussion of the theoretical literature on content choice in media markets. See also Liu, Putler and Weinberg (2004) and Godes, Ofek and Sarvary (2009) for applications to television markets.

${ }^{40}$ This discussion is adapted from the model presented in Armstrong (2005).
} 
$x$ increases with $q$. Adapting expression (3) implies that the broadcaster's total profit is

$$
x(P \mid q) R(P)-C(q),
$$

where $R$ is $R_{\text {pay }}$ or $R_{\text {free }}$ according to the regime.

If the broadcaster is unregulated, it chooses $(P, q)$ to maximize this expression. The broadcaster may be regulated in one dimension and be free to choose the other. The relevant comparative statics-e.g., how is quality affected by a constraint on price - depend on the precise way in which quality and price interact in the demand function. A simple case to illustrate the possibilities has quality expand the market proportionately, so that $x(P \mid q)=q X(P)$. In this case, (7) implies that the choice of $P$ does not depend on chosen quality. This implies that a regulation which forces the broadcaster to raise its programme quality, if feasible and if it does not cause it to go bankrupt, will benefit viewers.

If $X(P) R(P)$ is single-peaked in $P$ and total price is below the maximizing price, then the broadcaster's choice of quality is an increasing function of $P$. Thus, as is intuitive, when it is permitted to charge viewers a higher price, the broadcaster response by raising its quality. For example, consider a regulatory policy which puts a ceiling on advertising intensity in the free-to-air regime. For fixed quality, this policy surely benefits viewers, as lowers the effective price they pay. But the policy reduces the revenue per viewer the broadcaster can extract from advertisers, and this may reduce its incentive to invest in quality and the combined impact on viewers could be negative. Likewise, in the pay-TV regime, a regulatory ceiling on the direct charge the broadcaster can levy on viewers might be counter-productive once the firm's quality response to the lower price is taken into account. Finally, a regime shift from free-to-air to pay-TV, which we know will harm viewers with quality held constant, may benefit viewers once the firm's likely boost to its quality is factored in.

Another concern was the danger that competing broadcasters would duplicate programming, while a monopoly broadcaster could have greater incentive to provide diverse output. This is a genuine danger in a free-to-air market with limited channels, but less so with pay-TV. For instance, Steiner (1952) analyzes a rather extreme model where each viewer only considers watching a single type of content, and prefers to switch off rather than watch anything else. To illustrate, suppose there are just two types of channel, $A$ and $B$, with respective audiences $n_{A}$ and $n_{B}$ and per-viewer surplus $v_{A}$ and $v_{B}$. For simplicity, suppose that programme costs are zero and there is no viewer disutility from advertising. Then a monopoly broadcaster with two channels will choose to offer both types of channel in order to maximize its total audience. (This is true in both the free-to-air and the pay-TV regime.) In the ad-funded world where each of two channels is provided 
by a separate broadcaster, it may be that both choose to offer the same programme type 41

The general principle is that when broadcasters charge viewers directly for content, they have an incentive to differentiate their content in order to relax price competition. More modern treatments of this issue have tended to use a Hotelling model as a way to capture the choice of genre (or other aspects of content such as political stance). In such models, it is well known that when rivals cannot compete with price, there is a tendency to converge to the middle of the Hotelling line in a bid to maximize market share. This is a reasonable reflection of a free-to-air broadcasting market where broadcasters cannot affect advertising intensity (or viewers do not care about advertising intensity). As such, this model bears out the intuition that ad-funded broadcasters often offer the same fare. However, in a pay-TV regime where broadcasters can charge viewers directly, there is a tendency to choose locations which are far apart so as to relax price competition 42

Gabszewicz, Laussel and Sonnac (2001) study a Hotelling model when media duopolists first choose location and then compete for consumers. Consumers are assumed not to care about advertising intensity (i.e., $\delta=0$ in the above notation), and so a media outlet chooses its level of advertising purely to maximize advertising revenue. If this revenue is so great that outlets offer content for free to consumers, they find that the outlets duplicate their content, while if positive prices are offered in equilibrium the outlets differentiate their offerings. This analysis was extended by Peitz and Valletti (2008) to allow for advertising disutility (which is more relevant in television markets than in the newspaper context considered by Gabszewicz et al. (2001)). They find that with pay-TV, broadcasters differentiate their content to the maximum extent, as with Gabszewicz et al. (2001), while in the free-to-air regime broadcasters do differentiate their content to some extent, for otherwise competition for viewers who dislike ads would force their advertising levels to zero.

\subsection{Evaluating the Simple Model}

Testable implications Under its maintained assumptions, the preceding model produces a number of testable implications about differences in outcomes in ad-supported and pay (ad plus subscriber-supported)

\footnotetext{
${ }^{41}$ This is the case when audiences are significantly skewed, in the sense that $n_{A}>2 n_{B}$, when a broadcaster prefers to get half the mass market than all of the niche market.) However, if broadcasters can charge viewers, they are more likely to choose distinct programme types in equilibrium. (If they choose the same content $A$, say, competition drives the viewer price to zero, and they each obtain profit $\frac{1}{2} n_{A} r$, while if they choose distinct programme types they can extract viewer surplus, and so one firm obtains $n_{A}\left(r+v_{A}\right)$ and the other obtains $n_{B}\left(r+v_{B}\right)$. It is an equilibrium to choose distinct programme types when $\frac{1}{2} n_{A} r<n_{B}\left(r+v_{B}\right)$, which is a weaker condition than in the ad-funded regime.

${ }^{42}$ See d'Aspremont, Gabszewicz and Thisse (1979) for this analysis.
} 
television markets that I summarize here.

- Prices and Welfare: The total price to viewers (i.e. the subscription price plus the disutility from advertising) is higher in pay-TV than ad-TV under both monopoly and oligopoly, and that, conditional on the content being offered, viewers and advertisers are worse off in pay-TV, with broadcasters better off.

- Content Choice: Because of this increased profitability, broadcasters will offer more content in a pay-TV environment. Furthermore, where both free and paid content are available, lowest-commondenominator programming will be offered on free channels and niche programming will be offered on pay. Finally, we should see maximal content differentiation in a pay-TV oligopoly.

- Quality and Regulation: Optimal quality increases with total price (and thus should be higher in pay markets). Regulations that cap prices or advertising levels will lower quality and viewer surplus.

Unfortunately, one cannot take these predictions directly to the data, as there is a sizeable gap between the simple model's maintained assumptions and the institutional characteristics of TV markets, including multi-homing consumers, multi-dimensional preferences, multi-channel firms, competition within and between commercial broadcasters, public-service broadcasters, and pay-television providers, and unmodeled heterogeneity in utility of content, disutility of ads, costs of program production and quality choice, and regulatory constraints across countries. As an example, a model allowing heterogeneous disutility of ads and competition between a single broadcast and pay provider offering identical content but with a different mix of advertising versus subscriber payments would likely yield, in contrast to the first prediction above, (relatively) ad-loving consumers facing a lower total price from the broadcaster, ad-hating consumers facing a lower total price from the pay operator, and the consequent self-selection of consumers into the environment that suited them best 43

What can we learn? The theory instead has been useful in at least two distinct ways: identifying both the variables of economic interest and the mechanisms by which different economic environments (e.g., broadcast $\mathrm{v}$ pay support, monopoly $\mathrm{v}$ oligopoly) determine welfare outcomes in television markets, mechanisms

\footnotetext{
${ }^{43}$ My thanks to the Simon Anderson for this example. As a historical note, the television theory literature's focus on the tradeoffs between broadcast and pay-television regimes going back to Steiner (1952) and Beebe (1977) reflects the combination of capacity and regulatory constraints that limited the development of the pay-television sector. Pay television's large and growing dominance of television markets evident in Figures $9,12,13,14$ and 16 have, however, largely mooted this as a policy question. We all want our MTV.
} 
that are likely to continue to operate in richer theoretical environments, and identifying relevant model primitives on which to focus empirical research. As examples of the first type, I highlight several data patterns from Section 2 .

On the topic of content choice, the handful of networks in the US broadcasting sector described in Table 1 versus the hundreds of pay-television networks summarized in Tables 2 and 3 suggests the ability of pay-television networks to better extract viewer surplus may indeed enable them to offer more content than can ad-supported networks, particularly in a multichannel world that limits the ability to build the kinds of large audiences of greatest value to advertisers ${ }^{44}$ Similarly, the immense variety of available pay-television channels in these same tables suggests significant (if not maximal) content differentiation is occurring in pay-television markets. Whether the mechanism driving this differentiation is the desire of programmers to enhance market power over their audiences with advertisers (the motivation of the effect originally developed in Peitz and Valletti (2008) using a similarly stylized modeling environment) or to enhance market power over their subscribers in negotiations with distributors (an unmodelled effect) is an interesting open research question. Regarding quality choice, Figures 6 and 14 indicating the simultaneous growth in pay-television price and quality (as measured by programming expenditure) and constancy in broadcast television quality suggests the complementarity of quality and price identified in the simple model may be a robust theoretical prediction ${ }^{45}$ Further theoretical work on all these questions would be welcome.

As for empirical work identifying model primitives, Wilbur (2008) and Analysys Mason and BrandScience (2010) both estimate consumer sensitivity to advertising $(\delta)$, but obtain very different results: the former, using aggregate ratings data, estimates an elasticity of approximately -2.5 , while the latter, using household viewing data, estimates an elasticity indistinguishable from zero. As it is an important input into the welfare effects of advertising (and thus advertising-support), further estimates of this key parameter would be useful. Furthermore, several papers have estimated preferences for programming $(v)$, research on which I summarize in more detail in Section 4.4 below.

While welcome, there remain important features present even in the simple model that haven't received much if any attention in empirical work. Examples include accounting better for the simultaneous influence

\footnotetext{
${ }^{44}$ Similarly perhaps for program choice within networks of different types: Crawford (2007) found that there are important differences between the programming provided on broadcast versus cable networks, with "niche", or special-interest, programming less widely available on broadcast channels than is general-interest programming (and vice versa on pay).

${ }^{45} \mathrm{~A}$ final example is the possible concordance between the predictions of the simple model about subscriber price caps. That such caps would reduce quality has found support in the literature evaluating such regulations imposed by the 1992 Cable Act (Besanko, Donnenfeld and White (1987), Besanko, Donnenfeld and White (1988), Crawford (2000), Crawford and Shum (2007), Crawford (2013)). Assessing the quality effects of caps on advertising minutes remains an open question; see Analysys Mason and BrandScience (2010, Annex E), Crawford, Smith and Sturgeon (2012a), and Filistrucchi, Luini and Mangani (2010) for related research.
} 
of both subscriber and advertiser payments in influencing market outcomes 46 and analyzing content choice in television markets ${ }^{47}$ Other unanswered questions include how consumers trade off price versus quality, what factors influence firms' (possibly dynamic) quality choices, and determining what is the connection between competition and quality. These are all first-order inputs into television market welfare that require substantially more empirical research. The next section summarizes those extensions to the simple theory model that have been made and the empirical research that relies on them.

\section{Extensions to the simple model: "The Four Bs"}

While the simple model above gives important testable predictions about outcomes in television markets, there are aspects of the industry that are not included in the model that are important to understand its functioning, as well as how television markets differ from other media markets. I call these extensions the "Four Bs": Public Service Broadcasters, Bargaining, Barriers to Entry, and Bundling. I introduce each, discuss their theoretical consequences for the functioning of television markets, and provide evidence of their effects.

\subsection{Public Service Broadcasters}

\subsubsection{The Economic Rationale for PSBs}

A History of PSBs Especially in the era before pay-TV there was a clear danger of market failure in the provision of television. Advertising intensity could have been excessive, the cost of high-quality programming might not have been able to be recouped with advertising revenue alone, limited spectrum meant there could be only few rivals, and those rivals might anyway have offered duplicative content. One natural response to these problems was to promote "public service broadcasting" (PSB), either with a single designated PSB broadcaster or by imposing requirements on a number of commercial broadcasters. For example,

\footnotetext{
${ }^{46}$ Wilbur (2008) stands out as one of the few academic papers to incorporate both viewer and advertiser demand into a model of television markets, but he does so only for the broadcast sector. By contrast, Crawford et al. (2012a) estimate a model of advertiser (inverse) demand, but do not analyze viewer demand. Similarly, recent papers in the pay-tv sector, like Crawford and Yurukoglu (2012), incorporate the advertising sector, but in a reduced-form way that prevents evaluating advertiser welfare. This surely reflects both the modeling challenges needed to account for the pay-television supply chain and the difficulty obtaining the data necessary to analyze both the broadcast and pay-television branches and the subscriber and ad-supported sides of the market, but these barriers are being progressively lowered with time.

${ }^{47}$ Again Wilbur (2008) stands out, finding the programs offered on broadcast television align more closely with advertiser than viewer preferences. By contrast, research on program choice is common in radio markets; see ([zzz Anderson and Waldfogel chap zzz]) and ([zzz Sweeting chap zzz]) for analyses of the impact of market size and market concentration on product selection and program variety in radio.
} 
many viewers might be made better off if advertising on television was banned or reduced for some broadcasters, and the broadcaster's funding shortfall met from other sources. Viewers might benefit if expensive dramas or documentaries were produced, which would not be offered in a laissez-faire broadcasting market. Historically, the UK has had the best-known system of public service regulation in the world. A useful way to discuss the rationale and experience of PSBs is briefly to trace its early history in the UK, which is welldocumented through a number of committee reports commissioned by the UK government over the years ${ }^{48}$ The first such report, the 1923 Sykes Report, accompanied the formation of the BBC (initially the British Broadcasting Company, and then, from 1927, the British Broadcasting Corporation). The Sykes Report suggested that "the control of such a potential power [as radio held] over public opinion and the life of the nation ought to remain with the state", and it should not become an unregulated commercial monopoly. The report recommended that the $\mathrm{BBC}$ be funded using a licence fee levied on owners of radio sets, and that the BBC should not broadcast advertisements.

The Sykes Report only investigated the short-run issues associated with the formation of the broadcasting service, and in 1925 the Crawford Committee was directed to formulate guidelines for the longer-term operation of the BBC. This committee invited John Reith, the first director of the BBC during the period 1923 until 1938, to present a statement of his views of broadcasting. Reith, the son of a Scottish Presbyterian minister and holding strong religious beliefs himself, presented firm opinions on the proper purposes of broadcasting: "the preservation of a high moral tone is obviously of paramount importance"; "He who prides himself on giving what he thinks the public wants is often creating a fictitious demand for lower standards which he himself will then satisfy", and so on 49 Reith also felt that radio had a social and political function, and could be a powerful means to national unity. He cited a broadcast speech in 1924 by King George V, the first time the monarch had been heard on radio, as having the effect of "making the nation as one man". Broadcasting could also provide the facts surrounding an issue of the day, as well as the arguments on either side, and people could make up their own minds instead of accepting "the dictated and partial versions of others". Finally, Reith argued for "unity of control" - i.e., the maintenance of the BBC's broadcasting monopoly - so that "one general policy may be maintained throughout the country and definite standards promulgated.” The BBC was to keep this monopoly for the next 30 years.

The first committee in the television era, 1950's Beveridge Committee, had this monopoly as its focus. In

\footnotetext{
${ }^{48}$ This account is mostly taken from the excellent account by Scannell (1990). Parts are also taken from Armstrong (2005) and Armstrong and Weeds (2007).

${ }^{49}$ In private he was more trenchant. As reported on the BBC's webpage devoted to Reith, he wrote in his diary of his admiration for Nazi-era German broadcasting: "Germany has banned hot jazz and I'm sorry that we should be behind in dealing with this filthy product of modernity." After the war he was disgusted at a broadcast of greyhound racing, "the most significant manifestation of public depravity that I have seen”.
} 
its submission to the committee, the BBC argued strongly against ending its monopoly, since Gresham's Law would operate "as remorselessly in broadcasting as ever it did in currency. The good, in the long run, will inevitably be driven out by the bad. [...] And because competition in broadcasting must in the long run descend to a fight for the greatest number of listeners, it would be the lower forms of mass appetite which would more and more be catered for in programmes."

The Beveridge Committee recommended that the BBC monopoly be continued, but two years later, a newlyelected government rejected this, and in 1955 it established commercial television in the UK, funded by advertising. This Independent Television (ITV) had strict PSB obligations, and the new second television channel was not an alternative to public service broadcasting. An advertising-funded commercial broadcaster could be induced to supply specified kinds of programming in return for its license to operate. Having one of just two television channels meant that ITV would enjoy significant scarcity rents. (The phrase "a licence to print money" was coined when the first ITV licences were first awarded.) These rents could be used to fund programming that the regulatory authority wished to see provided, but which would not be supplied voluntarily by commercial broadcasters.

The next committee, 1960's Pilkington Committee, was charged with how to allocate a new, third television channel. Sir Harry Pilkington was very much a Reithian in outlook and concerned with pervasive "triviality". The committee found a lack of variety and originality and unwillingness to try challenging subject matter, and identified commercial television as the main culprit, which was unable to "understand the nature of quality or of triviality, nor the need to maintain one and counter the other." The committee awarded the third channel to the BBC.

Finally, we fast-forward to 1986, the heyday of Margaret Thatcher's government, and to the Peacock Committee, which was set up to investigate alternatives to the BBC's licence fee. This committee radically shifted the tone of the discussion in the UK, and treated broadcasting more like any other product. It wanted a broadcasting system to offer "full freedom of entry for programme makers, a transmissions system capable of carrying an indefinitely large number of programmes, [and] facilities for pay-per-programme or pay-perchannel". The committee recommended that in the medium term (the 1990s) the BBC should be funded by subscription, and that residual PSB requirements be financed from a fund open to all broadcasters.

PSBs as a response to market failure Armstrong and Weeds (2007) analyze in depth the extent to which PSBs can be rationalized as a response to market failure. Quoting Gavyn Davies, they give credence to the view that the mission of a PSB should not simply be to "inform, education, and entertain," but to "inform, 
educate, and entertain in a way which commercial broadcasters, left unregulated, would not do". They identify two possible market failures that PSBs might solve: (1) satisfying viewer preferences that might otherwise not be served and (2) accounting for externalities associated with various types of programming. On the first point, they argue that while such concerns may have been reasonable in a low-capacity world of the type present in the early days of the industry, they are much harder to defend now given the growth in content across countries in pay-television offerings. The second point, however, remains valid. While causality about the effects of television viewing is very hard to establish, a growing body of research argues that watching certain types of content negatively influences behavior 50 Whether this has increased or decreased with the widespread availability of multi-channel television is an open question. One thing is sure, however, while "in the early days of monopoly, the BBC could effectively force people to consume an austere diet of organ recitals, public announcements, and so on," this is less true in today's world where audiences are becoming ever more fragmented. This suggests that even if there remains a rationale for PSBs, there is a reduced ability to implement those goals, making this a challenging issue for both policymakers and the PSBs themselves.

Finally, granting the possibility of a market failure that a PSB could address, there is a question of implementation. Armstrong and Weeds (2007) argue that singling out funding for a single entity is potentially distortionary. While proponents have argued that such a policy could force competitors to "raise their game," there is no empirical evidence in support of this view and there is the reasonable possibility that such a policy could decrease rivals' incentives to invest in programming, at minimum in the PSB's programming areas.

\subsubsection{Effects of PSBs}

Despite its significant role in the functioning of most media markets and a consensus among academics, regulators, and the public at large about the importance of public service broadcasters for the functioning of a representative democracy, there is surprisingly little economic research supporting these beliefs 51 Following the widespread entry of commercial broadcasters in media markets worldwide, Prat and Strömberg (2006) build a model of a monopoly provider of broadcast television facing competitive entry and analyze the impact that entry has on programming choices, channel selection, and individuals' knowledge. They then test the implications of the model using Swedish survey data taken before and after the entry of a com-

\footnotetext{
${ }^{50}$ See, e.g., Hamilton (2000) regarding the connection between television and violence.

${ }^{51}$ Publicly-supported broadcasters also arise in radio markets, where they are an important (sometimes leading) provider of news and information. See [zzz Sweeting chap, section $4.8 \mathrm{zzz}$ ] for an analysis of the extent to which non-commercial content 'crowds out' commercial content.
} 
mercial television station, finding those that start watching the commercial station increase both their level of political knowledge and their political participation.

While thought-provoking, I share the views of Prat and Strömberg (2011) calling for significantly more research on the impact of PSBs, and not just on political outcomes. They argue that political information is a public good and that voters who spend resources obtaining information to keep their political leaders accountable produce a positive externality, providing one rationale for public funding of PSBs. But how big is this externality? Does a PSB provide a more valuable (e.g., less biased?) form of information compared to commercial producers? Are there other positive externalities of PSBs beyond disciplining politicians, for example on education or culture? What evidence is there for this? I share their call for greater data collection and dissemination by public broadcasters and greater emphasis on these questions by researchers.

\subsection{Bargaining}

One important feature of television markets that is frequently assumed away in theory models is the impact of the supply chain on market outcomes. Pay-television channel conglomerates like Disney or Viacom negotiate with pay-television distributors like Comcast or DirecTV over the price the latter will pay to the former for the right to offer the former's television channels on the latter's pay-tv bundles. Similarly, broadcast networks like $\mathrm{ABC}$ negotiate with stations (or station groups) over compensation for broadcast programming. This subsection describes the consequences such negotiations have on outcomes in television markets.

Bargaining Theory In television markets, it is reasonable to think that both content providers (channels) and distributors have market power. In such cases, it's unreasonable to think that either "sets a price"; rather they bargain to determine a mutually agreeable price. In such settings, non-cooperative bargaining theory has proven to be a useful tool to help understand market outcomes.

The insights of bargaining theory can be most easily understood in the context of bilateral monopolists, $A$ and $B$, bargaining over a pie of size $\pi 5^{52}$ The set of possible agreements is given by

$$
X=\left\{\left(x_{A}, x_{B}\right): 0 \leq x_{A} \leq \pi \text { and } x_{B}=\pi-x_{A}\right\}
$$

Utility to player $i$ from an agreement is $u_{i} \equiv U_{i}\left(x_{i}\right)$. If the players fail to reach an agreement, each gets a "disagreement utility" or "threat point", $d_{i} \geq U_{i}(0)$, with $d=\left(d_{A}, d_{B}\right)$. Let $\Omega$ be the set of utilities

\footnotetext{
${ }^{52}$ The exposition here broadly follows Muthoo (1999, Chapter 2).
} 
achievable through agreement, i.e.

$$
\Omega=\left\{\left(u_{A}, u_{B}\right): \exists x \in X \text { s.t. } U_{A}\left(x_{A}\right)=u_{A} \text { and } U_{B}\left(x_{B}\right)=u_{B}\right\}
$$

Then a "bargaining problem" is given by the pair $(\Omega, d)$

Nash (1950) established there is a unique solution to this bargaining problem that satisfies certain axioms of rational behavior 53 This was later generalized to account for asymmetries between the two players, yielding a solution called the Asymmetric Nash Bargaining Solution (ANBS).

Let $\tau \in(0,1)$ be the "bargaining power" for Player A (with $1-\tau$ being Player B's bargaining power) representing the strength of each player in negotiations. The ANBS of the bargaining game $(\Omega, d)$ is the unique pair of utilities that solves

$$
\max _{u_{A}, u_{B} \in \Theta}\left(u_{A}-d_{A}\right)^{\tau}\left(u_{B}-d_{B}\right)^{1-\tau}
$$

The solution to this problem is called the "Split-the-difference Rule". It says that the ANBS, $\left(u_{A}^{N}, u_{B}^{N}\right)$, is given by

$$
\begin{aligned}
& u_{A}^{N}=d_{A}+\tau\left(s-d_{A}-d_{B}\right) \\
& u_{B}^{N}=d_{B}+(1-\tau)\left(s-d_{A}-d_{B}\right)
\end{aligned}
$$

where $s$ is the "combined agreement surplus," the (utility) size of the pie to be split

The solution indicates that each party's utility from the bargain depends on three factors: (1) their threat point, $d_{i}$, (2) the "incremental surplus," $s-d_{A}-d_{B}$, i.e. the surplus the parties could earn from an agreement above and beyond what they could earn in the absence of the agreement (i.e. the "size of the pie" to be split), and (3) their bargaining power, $\tau$.

In addition to satisfying reasonable axioms about agent's behavior, Rubinstein (1982) later established that this ANBS solution was also the unique solution to a model of "alternating offers" that closely resembles how bargaining happens in practice. In this case, each party's bargaining power ( $\tau$ or $1-\tau)$ could be related to how patient each was in negotiations 54

Horn and Wolinsky (1988) extended the bilateral monopoly bargaining solution to that of bilateral oligopoly. This is important in television markets because the outcomes of bargains are interdependent: negotiations

\footnotetext{
${ }^{53}$ These are (1) Invariance to Equivalent Utility Representation, (2) Pareto Efficiency, (3) Symmetry, and (4) Independence of Irrelevant Alternatives (IIA).

${ }^{54}$ Where patience was measured by rate at which each party discounted future profits, with lower discount rates corresponding to higher bargaining power.
} 
yielding a low affiliate fee paid by one distributor to one channel impacts the profits made by other distributors (and channels).

The equilibrium concept they introduced was a "Nash Equilibrium in Nash Bargains," or "Nash-in-Nash". Each negotiating pair reaches an agreement conditional on all other agreements (i.e. pair-wise Nash Bargaining), and, in equilibrium, no pair wants to change their agreement given all other pairs' agreements (i.e. each pair-wise agreement is part of a Nash Equilibrium) ${ }_{55}^{55}$ The structure of the solution for each bargaining pair nonetheless follows that for bilateral monopolists described above.

Bargaining Empirics Crawford and Yurukoglu (2012) (hereafter CY), building on this theoretical literature and the empirical work of Ho (2009), construct an empirical model of demand, pricing, bundle choice, and bargaining to estimate bargaining parameters between channel conglomerates and large pay-television distributors in the US pay-television industry.

CY assume that the input costs ("affiliate fees") paid by distributors to channels are the outcome of bilateral negotiations between upstream channels, or channel conglomerates, and downstream distributors that meet and negotiate bilaterally in a separate and simultaneous manner. Following industry practice, they assume distributors (Multiple System Operators, or MSOs) negotiate on behalf of all their component systems and channel conglomerates bargain on behalf of their component channels. They bargain à la Nash to determine whether to form an agreement, and if so, at what input cost. The ultimate payoffs are determined by downstream competition at the agreed upon input costs. Following industry practice, CY assume that the agreements between conglomerates and distributors are simple linear fees of the form $\$ \mathrm{X}$-per-subscriberper-month.

CY estimate that most bargaining parameters are between 0.25 and 0.75 , discouraging models that assume take-it-or-leave-it offers on the part of either channels or distributors. They further estimate that distributors generally have higher bargaining parameters than channel conglomerates for small channel conglomerates (e.g. Rainbow Media or the content division of Comcast), but that the situation is reversed for large channel conglomerates (e.g. ABC Disney and Time Warner) ${ }^{56}$ Among distributors, small cable operators and satellite providers have slightly less estimated bargaining power than large cable operators. They also find that bargaining is an important factor in determining what outcomes would be in a world where distributors

\footnotetext{
${ }^{55}$ Like Rubinstein (1982), Collard-Wexler, Gowrisankaran and Lee (2012) similarly specify an alternating-offers representation of the interdependent bargains inherent in bilateral oligopoly bargaining.

${ }^{56}$ In the period CY study and for the 50 or so largest cable channels in their analysis, Rainbow Media owned AMC and WE: Women's Entertainment, Comcast owned E! Entertainment Television, the Golf Channel, and Versus, ABC Disney owned ABC Family Channel, Disney Channel, ESPN, ESPN2, Soap Net, and Toon Disney, and Time Warner owned the Cartoon Network, CNN, Court TV, TBS Superstation, and TNT.
} 
were forced to offer channels à la carte, a topic I discuss further at the end of this section.

\subsection{Barriers to Entry}

As noted by Anderson and Waldfogel in the first chapter in this volume ([zzz Anderson and Waldfogel chap zzz]), media markets are generally characterized by high fixed costs, preference heterogeneity, and advertiser support. One feature that distinguishes television from other media markets are the magnitudes of the fixed costs and that they are often sunk. This introduces important barriers to entry in both the upstream (channel) market as well as the downstream (distribution) market.

Market Power in Wholesale (Programming) Markets As evidence of these fixed costs, consider again Tables 1 2 2 that report the programming expenditure for leading broadcast and cable television channels. The average annual programming expenditure for even a minor broadcast network is upwards of $\$ 100$ million, with \$200 million required for a low-end top-25 cable network. Launching a channel requires a multi-year programming commitment, as well as administrative, technical, and marketing infrastructures that can easily push the fixed costs over $\$ 1$ billion. Furthermore, most of these costs are sunk: programming investments that prove unpopular cannot be recovered, as cannot many administrative and marketing costs. Furthermore, arranging carriage agreements with leading distributors, a necessary condition for the success of a television channel, are also expensive and uncertain. All these factors lead to significant entry barriers and encourage a concentrated upstream market structure.

Table 5 presents the ownership pattern of leading broadcast and cable programming networks in 2013, while Figure 17 displays the share of this upstream industry revenue that accrues to "Big Media", "Vertically Integrated Multiple System Operators (MSOs)", and "Other" owners. The table and figure show that seven firms dominate the production of video programming in the U.S. 57

There are both pro- and anti-competitive effects that could arise from this increased concentration. Increased firm size may yield economies of scale, greater facility developing and launching new program networks, and lower costs for investing in and deploying new programming and services. It may also, however, increase market power in the programming market, disadvantaging smaller channels and/or distributors. This has been a frequent issue discussed in the context of large media mergers like that between Comcast and AT\&T, which created the largest downstream distributor serving nearly $25 \%$ of the U.S. market (FCC (2002)). Some industry participants argue strongly that increasing consolidation is putting smaller

\footnotetext{
${ }^{57}$ Similar patterns of concentration have existed since at least 1998 (SNL Kagan (2014a)).
} 
distributors at a cost disadvantage in negotiations with channel conglomerates (FCC (2013b)) ${ }^{58}$

The conventional wisdom is that increased concentration in the distribution market improves the bargaining outcomes of those distributors, reducing affiliate fees to television channels in the programming market. The theoretical mechanisms, however, are not clear. In the bargaining approach summarized in the last subsection, increased size for an individual cable system reduces the viability of a program network if an agreement is not reached between the two parties. This necessarily lowers the network's "threat point." It also, however, lowers the threat point of the now-larger cable system, with the net effect unclear. Chipty and Snyder (1999) conclude that increased size downstream can actually reduce a cable system's bargaining power 59 Similarly, Raskovich (2003) builds a bargaining model with a pivotal buyer, one with whom an agreement is necessary for a seller's viability, and finds that being pivotal is disadvantageous as if an agreement is not reached the seller will not trade and it is only the pivotal buyer who can guarantee this outcome. This can reduce the incentives to merge if merging would make a buyer pivotal. Inderst and Montez (2015) formalize the tradeoff articulated above and obtain sharper results. They show that when buyer bargaining power is low, as CY found for cable systems negotiating with large channel conglomerates, increases in size are disadvantageous, but when buyer bargaining power is high, as CY found for cable systems negotiating with small channel conglomerates, increases in size do indeed lower input prices. This implication remains to be tested.

Assessing the consequences of increased market power in programming markets is conceptually simple, but a lack of data on transaction prices (affiliate fees) has prevented much empirical work. Ford and Jackson (1997) exploit rarely available programming cost data reported as part of the 1992 Cable Act regulations to assess (in part) the impact of buyer size and vertical integration on programming costs. Using data from a cross-section of 283 cable systems in 1993, they find important effects of MSO size and vertical affiliation on costs: the average/smallest MSO is estimated to pay $11 \% / 52 \%$ more than the largest MSO and vertically affiliated systems are estimated to pay 12-13\% less per subscriber per month. Chipty (1995) takes a different strategy: she infers the impact of system size on bargaining power from its influence on retail prices. She also finds support for the conventional wisdom that increased buyer size reduces systems' programming

\footnotetext{
${ }^{58} \mathrm{Cox}$, the fifth-largest distributor in the US, argues that the top four distributors exceed all others in terms of their bargaining power with programmers and this represents one of the most significant competitive threats that they face. The American Cable Association, an industry association representing small cable operators, also emphasizes the importance of scale by calling attention to the higher prices paid for video programming by small cable operators that lack scale economies.

${ }^{59}$ In their analysis, the size of the surplus to be split between a cable system and a programming network depends on the shape of the network's gross surplus function. They estimate this on 136 data points in the 1980s and early 1990s and find it is convex, implying it is better to act as two small operators than one big one. This convexity seems at odds both with the institutional relationship between network size and advertising revenue (which limits the ability of networks to obtain advertising revenue at low subscriber levels) as well as claims made by industry participants and observers of the benefits of increased size.
} 
costs. Finally, as discussed above, Crawford and Yurukoglu (2012) find that distributors generally have higher bargaining power than channels for small channel conglomerates, but that the situation is reversed for large channel conglomerates. The results of Inderst and Montez (2015) suggest the effects of merger depend critically on these bargaining power estimates. Further empirical research would be welcome.

Market Power in Retail (Distribution) Markets Similar concerns about market power arise in the downstream (distribution) market ${ }^{60}$ The average US pay-television market is served by a single incumbent cable television system, two satellite distributors, and (in some markets) the former incumbent telephone operator. When Verizon entered the video business, they were required to invest tens of billions of dollars upgrading their physical infrastructure for the delivery of video programming. This despite the fact that they, like AT\&T, had an advantage compared to other potential entrants in already serving the local market with telephone and Internet access services ${ }^{61}$ Similarly, so-called "overbuilders", independent entrants in the television business, have struggled to gain more than a miniscule portion of the television market.

Figure 6 demonstrated that prices have consistently risen faster than the rate of inflation in the US pay television market. Table 6, drawn from FCC reports on the status of competition in the programming market, reports concentration measures for the industry for several of the past 20 years. The sum of the market shares for the top 4, top 8, and top 25 MVPD providers have all increased over time, with the top 4 MVPDs serving $68 \%$ of the market and the top 8 serving $84 \%$ in 2010. The correlation between high and rising prices and increased concentration have driven concerns about high and rising market power in distribution. Of course, Figure 14 also shows that cable television channels have been spending more on programming, raising costs to downstream operators and challenging the ability to separate out price increases due to cost increases from those to due to market power. Furthermore, the entrant of satellite providers in the late 1990s and telco providers in the late 2000s (evident in Figure 4) have prompted policymakers to wonder if this is "enough" competition and/or whether instead price regulations might make consumers better off.

Turning first to regulatory effects, Mayo and Otsuka (1991) examined pre-deregulation cable prices in 1982 and found regulation significantly constrained their level. Rubinovitz (1993) examines the change in prices between 1984 (when they were still regulated) and 1990 (when they were not), finding the increased exercise of market power was responsible for $43 \%$ of the price increase in the period. Crawford and Shum (2007) find that regulation is associated with higher offered qualities, despite (slightly) higher prices.

\footnotetext{
${ }^{60}$ This subsection draws on material from Crawford (2013).

${ }^{61}$ The investment required is sufficiently expensive and uncertain that the third leading US telco, CenturyLink, has not chosen to provide television service except in select major urban markets.
} 
As for satellite competition, Goolsbee and Petrin (2004) estimate a flexible probit model of cable and satellite bundle demand, infer (otherwise unobservable) bundle quality from these estimates, and relate cable prices to satellite penetration controlling for quality. They find reducing satellite penetration to the minimum observed in their data would be associated with a 15\% increase in cable prices. Chu (2010) extends this by analyzing system quality responses and finds that, while there is widespread variation across systems in their strategic response, on average cable prices are slightly lower, but cable quality is significantly higher. The period since 2006 has witnessed a third wave of cable entry, that from telco operators. Industry accounts associated their entry with significant price competition, but only for the first several years after entry. Once they established a moderate presence, the conventional wisdom is that both significantly increased prices. More research on both the short- and long-run effects of telco entry is needed.

Horizontal Merger Review Concerns about market power both upstream and down arise most frequently in the context of horizontal merger review in television markets ${ }^{62}$ Because most cable systems have nonoverlapping service areas, mergers between cable operators often do not reduce competition in local paytelevision markets. As such, most recent proposals have been approved, both in the US and Europe 63 Conducting horizontal merger reviews would benefit from answers to several questions about television markets that the academic literature has not yet provided. Should programming markets be defined broadly or narrowly? What is the impact of increased size on bargaining power in programming markets? Are merger-related efficiencies likely? What of tacit collusion, upstream and/or down? Much more work is needed to address the basic questions regularly facing regulators and competition policymakers.

\footnotetext{
${ }^{62}$ I discuss vertical merger review in Section 5.2 below. See also ([zzz Foros et al chapter zzz]) for general issues with mergers in media markets

${ }^{63}$ The Comcast-Time Warner Cable merger announced in February 2014 was withdrawn after news broke in April 2015 that the US Department of Justice (DOJ) intended to challenge the merger. The concerns raised by the merger were largely not horizontal issues in the pay-television market, but horizontal issues in the broadband Internet access market and vertical issues arising from Comcast's ownership of significant programming assets. Charter Communications has since announced their intention to purchase Time Warner Cable. Previous to this, the last big US challenge to a horizontal pay-television merger was the Echostar-DirecTV deal in 2001, which would have combined the two national US satellite operators. By contrast, Europe has seen a horizontal merger wave in recent years (Willems (2014)). Recent deals in the in the distribution market include Canal Plus-Movistar TV in Spain, Kabel-UnityMedia (Liberty Media) in Germany , Ziggo-UPC Netherlands (Liberty Media) in the Netherlands, and VodafoneONO in Spain. Much of this activity is trans-national and may be driven by the anticipation of a single European digital market, with Liberty Global and Vodafone leading players in collecting (and perhaps ultimately connecting) pay-television systems across Europe.

${ }^{64}$ In the BSkyB-Ofcom PayTV inquiry, separate programming markets were defined (narrowly) for premium movies and premium sports. In the Comcast-NBCU merger, the FCC implicitly defined news and business news markets narrowly when imposing a "neighborhooding" condition in its approval of the proposed merger. Determining this question requires an understanding of substitutability of programs and program networks from the perspective of viewers and, ultimately, pay-television distributors. Data exists in principle to evaluate the former (tho indeed while substitutes at any point in time, channels may instead be complements in access decisions), while the latter depends on accurately modeling bargaining outcomes, particularly households' willingness to switch providers in the absence of content they value.
} 


\subsection{Preference heterogeneity and Bundling}

One common feature of preferences is media markets is their heterogeneity. Some people like to read the New York Times, while others prefer USA Today. Some like Miley Cyrus while others prefer J.S. Bach. And some like Fox News while others like MSNBC. Anderson and Waldfogel discuss the implications of preference heterogeneity and preference externalities in media markets, finding important connections between the size of media markets and outcomes like the number, variety, and quality of media products ([zzz Anderson and Waldfogel chap zzz]).

Television markets are both similar and different. They are similar in that consumers of television, as in other media markets, have significant heterogeneity in their preferences. They differ, however, in that the television channels bought by consumers are bundled together and sold as a package ${ }^{65}$ In this subsection, I discuss the implications of this bundling for outcomes in television markets.

Bundling theory In practice, many broadcasters supply a range of content to viewers, and heterogeneous viewers may prefer some kinds of content to other kinds. A particularly simple case is when a viewer values each piece of content additively, so that her willingness-to-pay for content $i$ is not affected by whether she also has access to content $j$. In this additive case, when the broadcaster retails its content independently, so that the price of a piece of content is independent of her consumption of other content, then the previous analysis applies without change. Both values and prices are additive, and there is no interaction between different content.

However, in the pay-TV regime the broadcaster in most cases can do better than this by bundling its content together as a package (Clearly, in the free-to-air context, channel bundling has no role to play. For simplicity, suppose in the following discussion that the broadcaster does not use advertising at all.) To illustrate most transparently, suppose instead of retailing its various content separately, the broadcaster sells its full range of content as a single bundle in return for a single price 67

The key point is that a viewer's valuation for the whole bundle is often more predictable (i.e., less idiosyncratic) than her values for individual pieces of content (Bakos and Brynjolfsson (1999), Crawford (2008)). This might be because of negative correlation in values for different types of content, so that those viewers

\footnotetext{
${ }^{65}$ Newspapers may also be considered bundles of heterogeneous content. Some of the effects discussed here may also apply in this setting.

${ }^{66}$ The pioneering articles on bundling are Stigler (1968) and Adams and Yellen (1976). The many-product discussion which follows is taken from Armstrong (1999b) and Bakos and Brynjolfsson (1999).

${ }^{67}$ More ornate schemes would allow viewers to pick and choose between different content, but the basic insight is seen most clearly with this "pure bundling" format.
} 
who particularly like content $i$ place less value on content $j$, and vice versa ${ }^{68}$ A deeper reason is that, even without negative correlation, idiosyncrasies in valuations tend to get "averaged out" when bundling is used. (The phenomenon is similar to the insight that a diversified portfolio is less risky for an investor than holding a single asset.) If a viewer's valuation for one kind of content is independently distributed from her tastes for other kinds of content, and if there are many pieces of content on offer, then the law of large numbers implies that her value for the bundle is highly predictable. The result may be that the broadcaster can extract a large fraction of viewer surplus with bundling, and relative to non-bundled pricing viewers may be harmed and total welfare may rise 69

As with the comparison between advertising-funded and pay-TV regimes, the fact that a broadcaster typically makes more profit when bundling is used implies that some content can be profitably supplied only if bundling is used. As a result, even if bundling often reduces consumer surplus for a given range of content, the fact that more content might be offered with bundling could lead to consumer gains from the practice 70 For similar reasons, an incumbent broadcaster with an existing portfolio of content may be willing to pay more for new content than a new entrant, since the latter is less able to achieve extra revenue obtained with bundling ${ }^{71}$ The result may support a tendency towards concentration in the market for content discussed in the previous subsection, due here to demand-side economies of scope rather than any supply-side economies of scope.

Bundling empirics A sizeable empirical literature has analyzed consumer demand for bundles of television channels. Mayo and Otsuka (1991) and Rubinovitz (1993) estimate demand for cable bundles and attempt to measure the impact of regulation on cable prices. Crandall and Furchtgott-Roth (1996, Chapter

\footnotetext{
${ }^{68}$ For example, suppose half the population value a sports channel at $\$ 10$ and a news channel at $\$ 2$, and remaining viewers have the reverse preferences. If the broadcaster had to set a separate price for each channel, it would charge $\$ 10$ for either channel and viewers would see only their preferred channel. However, if it set a price of $\$ 12$ for the bundle of both channels, all viewers would just be willing to pay this, and profit and welfare both rise.

${ }^{69}$ Continuing with the example in the previous footnote, suppose for any given piece of content half the viewers have value $£ 10$ and the rest have value $\$ 2$, and valuations are independently distributed across products. As before, with per-channel pricing, the broadcaster would set the price $\$ 10$ per channel, viewers would see only the content they value highly and average revenue per subscriber per channel is $\$ 5$. However, if there are many channels, most viewers place a high value on around $50 \%$ of these channels, and so most people are willing to pay around $\$ 6$ per channel for the bundle. The result is that the broadcaster can extract most of the surplus from most of the viewers by giving them the whole bundle, and welfare increases since most people see all available content.

${ }^{70}$ See Crawford and Cullen (2007) for an investigation of this tradeoff.

${ }^{71}$ In the running example, and incumbent broadcaster which already possess many pieces of content would be willing to pay up to $\$ 6$ per subscriber for an extra channel, while a stand-alone entrant could pay only $\$ 5$.
} 
3) and Crawford (2000) also estimate bundle demand and calculate the welfare effects of changes in prices and product offerings.

Goolsbee and Petrin (2004), Chu (2010), and Crawford and Yurukoglu (2012) are the most recent and comprehensive empirical papers analyzing demand for pay television bundles ${ }^{72}$ I summarize here CY as it builds demand for bundles from heterogeneous preferences for individual channels.

A challenge when estimating demand for bundles is to determine the relative importance of each channel in the purchase of the bundle when the bundle contains as many channels (50+) as is common in the paytelevision industry. Variation in the contents of bundles across cable markets, or across bundles of different size within cable markets, helps to trace out the demand for each component channel, but generally isn't rich enough to recover the full distribution of preferences for individual channels. Furthermore, these distributions are critical to understanding the core issues of pricing, content choice, and welfare both in existing television markets and how they may differ in different economic environments.

CY resolve this issue by pairing data on bundle composition and price with complementary data on individuals' viewing habits. The latter, both in the form of average ratings for channels across markets as well as individual households' viewing behavior, provide rich information at the level of individual channels, but do not have price information. It is only the combination of viewing data, that allows estimation of the relative utility of alternative channels, and bundle purchase data, that allows the translation of channel utility into bundle willingness-to-pay, that allow them to recover demand curves for individual channels.

Supported by evidence from viewing patterns in their data, CY also accommodate the "long tail" feature of preferences for media products. ${ }^{73}$ They do so by assuming that with some probability depending on demographics, households have a zero preference for cable channels. If positive, they further assume that the marginal distribution of preferences across households is distributed as an exponential. They then estimate the zero-taste probabilities and exponential parameters for each channel. They also estimate distributions for preferences allowing for positive or negative correlations in tastes for pairs of channels, an important consideration in the bundling literature ${ }^{74}$

Figure 18 reports both the share of positive willingness-to-pay (WTP) and, among those that are positive, the estimated WTP for each of nine popular cable channels arising from their analysis. Preference heterogeneity

\footnotetext{
${ }^{72}$ Other recent work includes Rennhoff and Serfes (2008a), Byzalov (2010), and Crawford, Shcherbakov and Shum (2012b).

${ }^{73}$ See Anderson (2006) for a general exposition of this issue and Shiller and Waldfogel (2011) for evidence of long-tail preferences for music.

${ }^{74}$ In subsequent research analyzing demand for both national cable television channels and Regional Sports Networks, Crawford, Lee, Whinston and Yurukoglu (2015) extend this demand model to allow for heterogeneous value of time between sports and nonsports channels, finding this is an important extension which is necessary to explain the relatively large affiliate fees sports networks are able to obtain in negotiations with distributors.
} 
is evident: some people (32\%) don't value the cable news channel CNN at all, while others value it at more than $\$ 20 /$ month ${ }^{75}$ Furthermore, preferences for each channel are estimated to have a long tail, with many valuing channels at or around $\$ 2 /$ month and only few at values at or above $\$ 10 /$ month.

Welfare effects of à la carte Crawford and Yurukoglu (2012) use the results of their analysis to evaluate the implications of the bundling theory summarized earlier as well as the policy of forcing cable channels to be offered on an à la carte basis, a policy sometimes proposed by policymakers in the pay television industry ${ }^{76}$ The results both confirm the bundling theory summarized above and refute its application to the specific case of television channels due to bargaining between channels and distributors.

In their counterfactual analysis, CY simulate market outcomes in one large and one small cable market, both competing with a "national" satellite provider. Outcomes are compared for two scenarios. In the first, baseline, scenario, distributors are assumed to set a fixed (bundle) fee for the 49 cable channels included in their analysis. In the second, "Full À La Carte" scenario, distributors are assumed to set a fixed fee for access to any channels and then individual channel prices for each of these 49 channels. Competition is between the single cable operator serving each market and the national satellite operator setting a common price in both markets.

Their baseline results confirm the predictions of the discriminatory theory of bundling summarized above: in an à la carte world, households would choose only 22 of 49 channels, expenditure on cable would fall by an estimated $23.8 \%$, and consumer surplus would rise by $19.2 \%$. Total industry profits would fall by $12.7 \%$, but the gains to consumers would outweigh the losses to firms and total surplus would increase ${ }^{77}$

There is an important weakness in these baseline results shared by previous papers looking at this topic: they treat the affiliate fees paid by cable systems to programmers as given. While consistent with most of the

\footnotetext{
${ }^{75}$ Furthermore, Table 4 in Crawford and Yurukoglu (2012) lists for each of the 50 cable channels in their analysis, the second channel for which households had most positively correlated preferences. For the 9 channels listed in Figure 18, these were TV Land (ABC Family), MTV2 (BET), Fox News (CNN), MTV (Comedy Central), Nickelodeon (Disney Channel), ESPN2 (ESPN), VH1 (MTV), USA (TNT) and TNT (USA).

${ }^{76}$ They also analyze the impact of channels being offered as a part of Theme Tiers as well as the Bundle-Sized Pricing strategy proposed in Chu, Leslie and Sorensen (2011).

${ }^{77}$ Previous research yielded qualitatively similar conclusions for consumer and firm surplus (though not for total surplus). Crawford (2008) tested the implications of the discriminatory theory and found qualified support for it, finding that bundling an average top-15 special-interest cable networks was estimated to increase profits and reduce consumer welfare, with an average effect of $4.7 \%(4.0 \%)$. In a simulation study, Crawford and Cullen (2007) confirmed these effects and also found that bundling enhances industry incentives to provide networks than would à la carte sales, but may do so at significant cost to consumers. Work by Rennhoff and Serfes (2008b), under somewhat restrictive assumptions, reaches similar conclusions about welfare effects of à la carte, while Byzalov (2010) finds the opposite result. CY's total surplus results are contrary to that predicted by theory, but can be rationalized as in their counterfactual, consumers pay fixed fees in order to access channels on an à la carte basis. This fixed fee itself acts similar to a bundle as consumers only pay it if the surplus given by the sum across channels of their WTP for each channel less its price exceeds the fixed fee. Many do so, purchasing a small number of channels, and this additional sales channel not present in the standard theory increases consumer and firm surplus sufficiently to tip make the total surplus effect positive.
} 
theory literature ${ }^{78}$ this is contrary to both the nature of programming contracts in the pay-television industry (which typically require systems to pay sometimes much higher fees if channels are offered à la carte) as well as bargaining incentives in an à la carte world. Crawford and Yurukoglu (2012) use their industry model of pay television markets to evaluate the welfare effects of à la carte allowing for renegotiation between programmers and distributors in an à la carte environment and find this has an important impact on the merits of such a policy. They estimate that renegotiation in an à la carte world would cause affiliate fees to rise by more than $100 \%$ on average, raising à la carte prices to households and lowering both consumer surplus and firm profits. On average, they find consumers would be no better off under à la carte and that any implementation or marketing costs would likely make them worse off. This should give pause to policymakers eyeing à la carte as a policy tool to increase consumer welfare in pay-television markets.

\section{Open Policy Issues in Television Markets}

A number of open theoretical and empirical policy issues currently demand the attention of regulators and policymakers around the world, drawing also the attention of academic research 79 This section briefly summarizes these topics.

\subsection{Wholesale bundling and competition in programming markets}

Bundling may not only be used to price discriminate ${ }^{80}$ Another recent literature analyzes how bundling can also be used to extend market power or deter entry (e.g. Whinston (1990), Nalebuff (2004), Peitz (2008), Hurkens, Jeon and Menicucci (2013)). Both Whinston (1990) and Nalebuff (2004) demonstrate settings in which a monopolist in one product bundles a potentially or partially competitive second product with his monopoly product and either prevents entry or reduces the profitability of a potential entrant in the second product. As highlighted by Peitz (2008), Whinston (1990) requires commitment on the part of the monopolist - in the case entry was not foreclosed, she would prefer not to bundle - and Nalebuff (2004) requires sequentiality - if both choose prices simultaneously rather than having the monopolist go first, then independent pricing rather than bundling is more effective at preventing entry.

Hurkens et al. (2013), building on this literature (and especially Peitz (2008)), demonstrate that a dominant firm can, in some cases, credibly build an entry barrier by bundling. The intuition stems from the two effects

\footnotetext{
${ }^{78}$ For an important exception, see Rennhoff and Serfes (2009).

${ }^{79}$ For a view contrary to the belief that more television is always to the good, see the interesting discussion citing sociological research in Armstrong (2005, IV.3).

${ }^{80}$ See Section 4.4 above
} 
bundling has on consumer demand: it increases it (what the authors call the demand size effect) and it makes it more elastic (the demand elasticity effect) ${ }^{81}$ A key parameter in their model is $\alpha$, measuring the extent to which the goods offered by a dominant firm are preferred to those offered by its rival. For intermediate values of dominance, they find that bundling can favor a dominant incumbent and disadvantage a rival. Allowing for entry costs, bundling can therefore foreclose competitive entry, with uncertain welfare effects. The potential for bundling to impact competition between channels in television markets has long been a concern of industry participants and policymakers in the U.S. In this context, bundling refers to the requirement that distributors negotiating with channel conglomerates that own both more and less valuable channels distribute the less valuable channels they don't necessarily like or want in order to distribute the valuable channels they feel are essential ${ }^{82}$ This may impact the ability of independent channels to enter and compete in the programming market.

Distributors have complained about the bundling of affiliated program networks, both when negotiating rights to broadcast networks under retransmission consent as well as critical non-broadcast networks (FCC (2005a, Paragraphs 162), FCC (2005b, Footnote 232)). One small cable operator called such tying, along with restrictions on tiering, "[one of the] two biggest issues that small and rural [cable] operators face today." (Communications Daily (2011)) In early 2013, Cablevision, a major US cable operator, sued Viacom, a major content provider, over the practice, claiming "Viacom's abuse of its market power over access to commercially critical networks ... force Cablevision to license and distribute ... some dozen other Viacom networks ... that many Cablevision subscribers do not watch and for which Cablevision would prefer to substitute competing networks." (Cablevision Systems Corp (2013))

Policy responses to this issue are ongoing. The FCC announced a new proceeding to investigate the issue in late 2007, but no formal rulemaking appears to have come from it (Cauley (2007)). In May of 2013, Senator John McCain introduced a bill promoting à la carte at both wholesale and retail levels, but this too has stalled. Despite both strong theoretical grounds for its possibility and industry and policymaker interest in the issue, I know of no empirical evidence of either entry deterrence or competitive effects of bundling or tying by channel conglomerates in the television programming market, so empirical studies of this topic would be welcome.

\footnotetext{
${ }^{81}$ See also Crawford (2008) for an exposition of these two effects in an empirical application to the cable industry.

${ }^{82}$ Since it is typically only one or a small number of channels that are driving this behavior by channel conglomerates, this issue has also been called "tying" in the trade press. A bundle is no more than a two-sided tie; the economic incentives are similar.
} 


\subsection{Vertical Integration and Foreclosure}

Access to essential ("must-have") content has become an increasingly important issue in pay television markets. Exactly which channels qualify for this designation isn't clear, with distributors in US pay television markets emphasizing sports and broadcast channels (FCC (2011b)) and regulators in the UK market emphasizing sports and film (movie) content (Ofcom (2009a)). The analysis of the competitive and welfare effects of exclusive access to valuable content by distributors integrated with the relevant content providers, is therefore an active topic of economic research 83

Vertical Integration Anti-competitive concerns are germane when a single firm owns both essential content and a distribution platform. When an integrated operator owns access to essential content, it may not allow at all the distribution of that content to rival distributors (so-called "refusal to deal") and/or it may negotiate prices that raise rival distributors" costs. Rey and Tirole (2007) call these "complete" and "partial foreclosure." Riordan (2008) summarizes the theoretical justification for concerns about vertical integration in general. Most relevant to video markets are theories relating to complete foreclosure, or refusal to deal, raising (downstream) rivals' costs, and reducing (upstream) rivals' revenues.

Even if they agree to license such content to rivals, an integrated programmer-distributor could raise the costs they pay relative to that of its integrated downstream division or reduce the revenue they receive relative to its integrated upstream division (Salop and Scheffman (1983), Riordan (1984), Ordover, Saloner and Salop (1990)). Downstream foreclosure was the primary motivator underlying the exclusivity prohibition for affiliated content in the U.S. program access rules (discussed below) as well as the reason for several merger conditions required by the FCC in its approval of the 2011 Comcast-NBC/Universal merger (FCC (2011c)). Similarly, concerns about upstream foreclosure drove the news neighborhooding condition in that merger due to concerns about the incipient integration of MSNBC, the dominant network for business news, with Comcast, the largest MVPD and one with important footprints in several very large markets for business news. The latter case is instructive, as the concern addressed by the merger condition was not (necessarily) one of complete foreclosure, i.e. that Comcast would no longer carry rival business news networks, but that it would disadvantage them in terms of channel placement, reducing viewership and thus rivals' advertising revenue. This highlights the subtle ways in which an integrated firm with market power in one market can disadvantage rivals in vertically-related markets.

\footnotetext{
${ }^{83}$ There is also a literature analyzing the competitive effects of exclusive dealing between unintegrated channels and distributors, particularly of premium movie and sports content. See Armstrong (1999a), Harbord and Ottaviani (2001), Stennek (2014), Madden and Pezzino (2013), and Weeds (2015).
} 
Of course, there are also efficiency reasons programmers and distributors may want to integrate. Bresnahan and Levin (2012) summarize the efficiency motivations for merger in general; several of these are salient for television markets. For example, vertical integration could eliminate double marginalization, as discussed above a potentially serious issue due to the widespread use of linear fees for content ${ }^{84}$ Similarly, it could minimize transactions costs and reduce the risk of new program development, or better coordinate investments in complementary technologies, a particularly important issue given the challenging licensing issues posed by the advent of online video. It could also internalize important externalities between programmers and distributors in the areas of product choice, service quality, and brand development. Or it could eliminate inefficiencies in the bargaining process, a potentially important issue given the increasing frequency of disruptions in this process.

Determining whether vertical integration is motivated by strategic or efficiency considerations is a challenging undertaking. Existing empirical research has universally found that vertically integrated MVPDs are more likely to carry their affiliated program networks, but whether this is pro- or anti-competitive remains an open issue. Waterman and Weiss (1996) examine the impact of vertical relationships between pay networks and cable operators in 1989. They find that affiliated MSOs are more likely to carry their own and less likely to carry rival networks. Subscribership follows the same pattern, though they find no estimated effect on prices ${ }^{85}$ Chipty (2001) addresses similar questions, including whether integration influences MVPD carriage of Basic cable networks. Using 1991 data, she finds integration with premium networks is associated with fewer premium nets, fewer basic movie networks (AMC), higher premium prices, and higher premium subscriptions. On balance she finds households in integrated markets have higher welfare than those in unintegrated markets, although the effects are not statistically significant. As in the studies analyzing the impact of regulation, however, it is difficult to assess if differences across cable systems in product offerings and prices are driven exclusively by integration or by other features of integrated systems (e.g. size, marketing, etc.).

Crawford et al. (2015) measure the efficiency and foreclosure incentives in the carriage and pricing of US Regional Sports Networks (RSNs) as well as the welfare effects of vertical integration in the presence of regulatory controls. They parameterize and estimate the incentives of upstream RSNs and their integrated downstream distributors to internalize both (1) the costs of double marginalization and (2) the benefits

\footnotetext{
${ }^{84}$ Bonanno and Vickers (1988) demonstrate that when two manufacturers (channels) compete, selling through an independent retailer using a two-part tariff with positive markup helps soften competition between them. In their setting, each channel extracts all the surplus from the retailer with the fixed (franchise) fee. In a related paper, Gal-Or (1991) shows that the same effects arise with simple linear fees: upstream manufacturers (channels) raise (upstream) markups above zero, trading off profit losses from double marginalization against profit gains from softer competition downstream.

${ }^{85}$ See also Waterman and Weiss (1997) for the impact of integration on carriage of basic cable networks.
} 
to the integrated downstream distributor of foreclosing his rivals' access to the RSN. They find large but not complete internalization of both efficiency and foreclosure incentives. They further find that vertical integration in the presence of (perfect) regulation requiring non-discriminatory access to integrated content (like the Program Access rules discussed below) leads to significant gains in both consumer and total surplus, but that in the absence of such regulations, integrated RSNs either completely foreclose or raise costs to rivals by $30 \%$, lowering consumer surplus.

Policy Responses There have been a number of policy responses to concerns about vertical integration and foreclosure in television markets 86 In the US, the 1992 Cable Act included regulations designed to promote non-discrimination in whole television markets. These are called the "Program Access" and "Program Carriage" rules. These forbid affiliated MVPDs and networks from discriminating against unaffiliated rivals in either the programming (Program Carriage) or distribution (Program Access) markets (FCC (2013b)). They also ruled out exclusive agreements between cable operators and their affiliated networks for rolling 5-year periods ${ }^{87}$ This prohibition was allowed to lapse in 2012 and was replaced by rules giving the Commission the right to review any programming agreement for anti-competitive effects on a case-by-case basis under the 2010 "unfair acts" rules (FCC (2012d)). The new case-by-case rules include a (rebuttable) presumption that exclusive deals with RSNs are unfair.

As discussed in many of the FCC documents cited above, the Program Access rules are perceived to have been a very successful policy to promote competition in the distribution market. Fostering this success has been the historical development of the cable industry. Because there are many cable operators licensing the same content across the U.S., including multiple operators of similar (large) size, there are useful comparators when evaluating whether an agreement reached between a content provider and an unaffiliated distributor is discriminatory. This is more challenging, however, for Program Carriage complaints. When a channel argues that it's being discriminated against, the best comparator would be contracts between the distributor in question and a "comparable" channel. Because the programming on each channel is different, however, finding a good comparison can be challenging.

Internationally, pay-television distribution tends to be dominated within a given country by a small of distributors, limiting the feasibility of regulations modeled on the U.S. Program Access rules. Instead, many

\footnotetext{
${ }^{86}$ In this subsection, I focus on policy responses in television markets. In the next section, I revisit this issue for online video markets.

${ }^{87}$ But for programming that was delivered by terrestrial technologies (i.e. microwave not satellite). This so-called "terrestrial loophole" was used by distributors in a handful of geographic television markets to exclusively offer highly valued regional sports networks (RSNs). This loophole was closed in 2010 as part of a new set of rules prohibiting "unfair acts" (FCC (2012b)).
} 
media and communications regulators have chosen more direct interventions in the market. In the UK, Ofcom in 2010 implemented a wholesale must-offer regime for the distribution of sports channels Sky Sports 1 and 2, with prices set by the regulator (Ofcom (2010a)). They later the same year referred the licensing of pay (movie) television packages to the UK Competition Commission (UKCC) for a market investigation (Ofcom (2010b)), but the UKCC found in 2012 that Sky's market position in relation to the acquisition and distribution of movies in the first pay window does not adversely affect competition in the pay-TV retail (distribution) market (UK Competition Commission (2012)). On the continent, the EC and national competition regulators have imposed various types of wholesale must-offer regulations as conditions of approval of mergers between major pay-television distributors in Italy, France, and Spain (Ofcom (2009b)). These have been largely perceived to be unsuccessful as they did not cover the content identified by rival distributors as essential to offering a competitive pay-tv package. Furthermore, it is not clear if and how sector regulators can address these deficiencies. Further research on the functioning of content licensing across pay-television markets would be useful to establishing best practices to enhance the functioning of these markets.

Vertical Merger Review Policymakers' primary inflection point in addressing concerns about vertical foreclosure in television markets is in the context of reviews of vertical mergers ${ }^{88}$ Almost all of the highest-profile competition reviews in television markets have focused on vertical issues; Figure 19 shows the vertical links between major content conglomerates and pay television distributors in 2012. In the US, this includes mergers like Comcast/TimeWarner-Adelphia (2005, approved with conditions), ComcastNBC/Universal (2011, approved with conditions), and Comcast-TimeWarner (2014-15, challenged and withdrawn) ${ }^{89}$ Similarly in Europe, with major cases including the CanalSat-TPS merger (France, 2006, approved with conditions) and the BSkyB-Ofcom pay-television investigation (UK, 2012, wholesale mustoffer regime imposed).

Conducting vertical merger reviews would also benefit from answers to several questions about television markets that the academic literature has not yet provided. Articulating the incentives facing integrated operators to raise rivals' costs, reduce rivals' revenues, and/or foreclose is straightforward, but measuring the key factors can be difficult. For example, what is the cross-elasticity of demand between downstream rivals in the absence of critical integrated content $2^{90}$ Furthermore, what are integrated firms' dynamic incentives

\footnotetext{
${ }^{88}$ I discuss horizontal merger review in Section 4.3 above. See also ([zzz Foros et al chapter zzz]) for general issues with mergers in media markets

${ }^{89}$ The analyses in these decisions often make for good reading about the relevant issues, e.g. FCC (2011c).

${ }^{90}$ This is a key input when evaluating the incentives to foreclose a downstream rival by withholding critical upstream content. As it is not generally measurable using existing data (as the key content is typically everywhere available pre-merger), a structural industry model like that used by Crawford et al. (2015) can provide an estimate of just such a counterfactual elasticity, but the
} 
to foreclosure (e.g. via changes in quality investment upstream, in infrastructure investment downstream)? How well do merger conditions and/or sector regulations mitigate harm? And how can one measure vertical efficiencies? Further work building knowledge that might serve as reference points to regulators, particularly but not exclusively in Europe, would be welcome.

\section{Online Video Markets}

Online video means watching video programming through an Internet distribution channel. In this sense, it is only differentiated from free or pay television by its distribution access technology and the specific device on which it is watched. Across the world, there are a large number of online video distributors (OVDs), distribution technologies, consumer devices, and business models. This section surveys this growing industry and discusses two policy issues that touch on its development: Net Neutrality and Foreclosure 91

\subsection{Online Video Facts}

With the rise of broadband Internet access to households and Internet-ready devices has come an increase in households' desire to watch video distributed through the Internet 92 In the US, an estimated $85.7 \%$ of US households will purchase to a high-speed data (HSD) connection in 2014, making the consumption of online video feasible for the majority of US households. Figure 20 shows that over-the-top Internet television (OTT) is estimated to be a significant and growing part of the television and online video industry. As discussed in ([zzz Wilbur chap zzz]), by 2013 smartphone and tablet penetration in the US reached 74\% and $52 \%$, respectively 93

While relationships governing the distribution of video content are well-established in the free and pay segments of the television industry, they are still being formed in the online video segment. While owners of programming content like movie studios generally license the distribution of that content through well-

detailed modeling and estimation involved is likely to be infeasible in the context of a typical merger review.

${ }^{91}$ In this section, I will follow the strategy taken by FCC (2013b, pp111-157) and analyze only "entities that offer video content akin to the professional programming traditionally offered by broadcast stations, or broadcast and cable networks, and which is usually created or produced by media and entertainment companies using professional-grade equipment, talent, and production crews that hold or maintain the rights for distribution." This excludes user-generated content of the type publicly available on video-sharing sites like YouTube.

${ }^{92}$ Broadband is defined in different ways by different organizations. FCC (2013b, p125), citing Bernstein Research and SNL Kagan, estimates standard definition video requires an Internet connection of 2 Megabits-per-second (Mbps) and high-definition video requires one of 4-8 Mbps. The National Broadband Plan, when discussing broadband availability in the US, reports on the availability of service by distributors providing actual download speeds of 4 Mbps (FCC (2010a, p20)).

${ }^{93}$ That being said, Wilbur notes that despite their proliferation, most consumers are not choosing to watch online video on these devices, (presumably) preferring either a computer or an Internet-connected television. 
established distribution windows (premium channels like HBO, cable channels like A\&E, broadcast channels like $\mathrm{ABC}$ ), different owners of content have taken different strategies for making that content available online. All are sensitive about disrupting existing distribution relationships with conventional distributors, but are eager for the incremental revenue online access can provide. For example, at the time of publication, Sony Pictures Entertainment licenses many of the television programs and films in its television and movie library for distribution on conventional linear television channels as well as on an on-demand basis on the advertising-supported online video service, Crackle. Crackle is itself available online at crackle.com, as an app for smart phones and tablets for both iOS and Android operating systems, on game consoles PS3 and Xbox 360, on Sony Blu-ray players, on Roku boxes and Apple TVs, and integrated with Bravia TVs. By contrast, some of the content already licensed to the premium channel HBO may be accessed via HBO GO (formerly $\mathrm{HBO}$ on Broadband) from a similarly wide variety of devices and platforms.

Distributors of online video content in the US can be divided into four (not-necessarily-mutually-exclusive) types 94

1. Over-The-Top aggregators (OTT aggregators) of original and licensed content 95

2. Conventional pay-television distributors that provide access to live linear and on-demand content on multiple screens, typically but not exclusively within the home (e.g., TV Everywhere),

3. Individual content owners, especially sports leagues (MLB, NBA), and

4. Device manufacturers that either license content directly or partner with providers in one of the previous three groups ${ }^{96}$

A survey by SNL Kagan of online video services across 35 countries reported 710 OTT aggregators, TV Everywhere providers, and device manufacturers, an average of 20.3 services per country (SNL Kagan (2012)).

At the end of 2012, North American Internet usage on fixed networks had grown by 120\% (Haider (2012)) Much of this was driven by the grown in online video consumption, particularly Netflix. "Audio and video

\footnotetext{
${ }^{94}$ While they could reasonably be included, for reasons of data availability I exclude from this short survey "catch-up" TV services that allow for temporary, "sync and go," downloading of content for later (perhaps offline) viewing like Tivo in the US and the BBC iPlayer in the UK. These are usually free to households that subscribe to another type of broadcast or pay television service.

${ }^{95}$ Examples of providers in this group include fee- and ad-supported subscription services (Netflix, Hulu, Amazon Prime) and rental and electronic sell-through (EST) (transactional) service providers (iTunes, Amazon Instant Video, Vudu).

${ }^{96}$ Examples of providers in this group include manufacturers of stand-alone OTT devices (Roku, Apple TV), tablet and smartphone manufacturers (iPad, Kindle Fire, iPhone, Samsung Galaxy), game console manufacturers (Sony PlayStation 3, Microsoft Xbox 360), and manufacturers of "connected TVs" (Sony, Samsung, Sharp, Vizio).
} 
streaming account for $65 \%$ of all downstream traffic [on North America fixed networks] from 9pm-12am and half of that [33.0\%] is Netflix traffic." Amazon, Hulu, and HBO Go accounted for 1.8\%, 1.4\%, and 0.5\% of peak traffic. Real-time entertainment, dominated by streaming audio and video, accounted for $67.4 \%$ of peak download traffic, with Netflix accounting for $46.9 \%$ of that amount. Peak traffic in Europe is less dominated by audio and video $(47.4 \%)$, but this is no doubt due to lesser availability of OTT providers. ${ }^{97}$

Online video distributors differ in both their sources and amounts of revenue. According to SNL Kagan, paid subscription services (Netflix, Hulu Plus) earned \$2.6 billion in revenue, or $40.0 \%$ of the online video industry's estimated total of $\$ 6.4$ billion (SNL Kagan (2014a)). Video advertising, including both ad-supported subscription services (Hulu) and non-professional video (YouTube), earned an estimated $\$ 2.5$ billion, or $38.7 \% 98$ Transactional services (EST and Rentals) earned the remaining 21.3\% 99 Online video distributors also differ in whether or not viewers can access live linear television, from where they access it (inside/outside their home), the number of titles in their film and television libraries, whether they include advertising or not, and their price. All of these relationships are in a state of flux.

\subsection{Net Neutrality and Foreclosure in Online Video Markets}

Two policy issues have arisen with the growth of online video: Net Neutrality and Foreclosure 100

Net Neutrality and Online Video Proponents of Net Neutrality articulate it as a principle of openness such that all Internet traffic is treated equally by distributors. In practice, this principle has been interpreted as preventing both (1) charging content (edge) providers from accessing users (i.e. requiring "zero-pricing") and (2) price discriminating across content providers for access (Lee and Wu (2009)).

In the US, the FCC has argued that an open Internet promotes innovation, investment, competition, free expression, and other important policy goals (FCC (2010b)). In 2005, the FCC articulated a Broadband (Internet) Policy Statement articulating four principles of an open Internet and followed this in 2010 with an Open Internet Order adopting three basic rules: transparency, no blocking, and no unreasonable discrimination (FCC (2010b)). In January 2014, the U.S. Court of Appeals for the District of Columbia Circuit vacated the anti-blocking and anti-discrimination aspects of the Open Internet Order. Netflix saw its share price drop

\footnotetext{
${ }^{97}$ Similarly, filesharing's share of peak download traffic on European fixed-line networks is just over double that in North America, although it has been declining over time.

${ }^{98}$ This is mostly due to non-professional video. Hulu's estimated 2012 revenues were $\$ 441$ million, or $17.7 \%$ of this total.

${ }^{99} \mathrm{TV}$ Everywhere services in the US are uniformly offered as an add-on service to a conventional pay-television bundle and so earn no subscription revenue, although they do earn some advertising revenue.

${ }^{100}$ Some of this section draws on similar material from Crawford (2013). Chapter zzz by Peitz and Reisinger discuss Net Neutrality in further detail.
} 
by $5 \%$ on the morning of the news and by $13 \%$ from its pre-Christmas peak as analysts envisioned "hundreds of millions of dollars in data subsidies" (SNL Kagan (2014b)). This followed an early-January announcement by AT\&T allowing content providers the ability to pay for customers' data use, a clear example of behavior such regulations were trying to prevent. Zero-pricing was clearly under threat.

In March, 2015, the FCC responded to the courts by setting strong rules in favor of Net Neutrality (FCC (2015)). These included regulating broadband Internet access providers under Title II of the Communications Act, giving them much broader regulatory powers, and explicitly prohibiting three practices that embody a non-neutral Internet: blocking, throttling, and paid prioritization. It applied the rules equally to both fixed and mobile Internet providers ${ }^{101}$ In the EU, by contrast, there are no clear pan-national rules. As part of the "Digital Agenda for Europe", the European Commission in September 2013 proposed measures that include a guarantee of Net Neutrality, and in April 2014, the European Parliament strengthened these proposals. The 28 member states need to next agree to the rules within the Parliament. At the time of this writing, this process is very much in doubt (Robinson (2014)).

The tradeoffs embodied in arguments over Net Neutrality are particularly salient for online video given its dominance of broadband traffic. Proponents of Net Neutrality argue it is needed to foster innovation and prevent the foreclosure of online video entrants. Opponents argue discrimination allows for more efficient network management and would enhance investments by both content providers and distributors, increasing consumer welfare. While the academic literature is replete with theoretical models incorporating such tradeoffs, empirical evidence of these effects are scarce. The only paper I know to address the issue with observational data is Nurski (2014), who explores the issue in using detailed UK data. She estimates demand for broadband video access and online video consumption, finding that both are sensitive to connection speeds 102 She then simulates the effect of the entry of online video content in a world with net neutrality and another with discrimination, finding discrimination only increases entry for content providers with high fixed costs of production. Much more work is needed in this area.

Foreclosure in Online Video Markets The non-discrimination terms vacated by the U.S. Appeals Court also raise the possibility that issues similar to those discussed in Section 5.2 above regarding the incentives an integrated pay television provider might have to foreclose, either partially or completely, a rival upstream content provider. Online video distributors must necessarily rely on a high-speed broadband connection to households in order to deliver their programming, the vast majority of which are also owned by existing

\footnotetext{
${ }^{101}$ The Order did not, however, apply these rules to connections between content and broadband providers that were the focus of Netflix's agreements with Comcast and Verizon, instead choosing to review these on a case-by-case basis.

${ }^{102}$ Lee and Kim (2014) also look at the issue by surveying roughly 500 Internet users.
} 
cable or telco MVPDs. There are therefore legitimate concerns that MVPDs will somehow manipulate their broadband networks in ways that disadvantage rival OVDs, perhaps by offering differential download speeds for rival online content, imposing data caps that lower the value of an Internet-delivered video service, or setting usage-based prices with similar effects $\sqrt{103}$ Furthermore, it is hard to determine if such strategies are anti-competitive, as they can also help MVPDs efficiently manage their network traffic.

The market for online video distribution is in its infancy, so appropriate policies are difficult to determine on either a theoretical or empirical basis. Rubinfeld and Singer (2001) demonstrate the typical foreclosure calculus in the context of the AOL-Time Warner merger and Farrell and Weiser (2003) analyze foreclosure incentives in the context of the FCC's Computer Inquires, the Microsoft case, and the then-nascent FCC Broadband proceedings.

In the Comcast/NBC-Universal merger, FCC (2011c) evaluated the potential for foreclosure online by analyzing the merged entities' historical tendency to favor integrated and discriminate against unintegrated programming in television markets. Furthermore, the potential for online foreclosure motivated many of the conditions imposed by the FCC in its ultimate approval of the merger (FCC (2011c), Baker, Bykowsky, DeGraba, LaFontaine, Ralph and Sharkey (2011)). That ruling found that, absent conditions preventing it, the merged entity would have the ability and incentive to hinder the development of competition in the online video marketplace. A key element of its merger approval was a condition requiring the merged entity to license NBC content on non-discriminatory terms to rival unintegrated online video distributors in a manner similar to the Program Access rules, imposing a new baseball-style arbitration procedure to help enforce it in a timely manner.

These are all contentious policy issues that are being debated by competition and sector regulators around the world. More empirical research establishing some basic facts about the nature of traditional and online television substitutability, measuring the incentives to foreclosure, and distinguishing between efficient and foreclosing MVPD management practices would be welcome.

\section{Conclusions}

Watching television is the dominant leisure activity for hundreds of millions of individuals and, unlike many media markets, it has continued to grow despite the rising popularity of the Internet and online video. This is particularly true of pay television, now the dominant medium in the US in terms of both ratings and revenue

\footnotetext{
${ }^{103}$ The same issues are at play in the issue of search bias discussed by ([zzz Peitz and Reisinger chap zzz]).
} 
and well-established abroad.

The purpose of this chapter has been to summarize the state of academic research on television and online video markets. Looking across the material surveyed here, it is somewhat difficult to connect the disparate themes. Economic research in television markets resembles an archipelago of distinct topics rather than a coherent canon. The theory literature has identified important differences in predicted ad levels, program content, prices, and welfare in simple models of ad-supported and mixed (ad and subscriber-supported) television markets and (perhaps declining) rationales for the support of public-service broadcasting. Bundling and bargaining (and their combination) have proven important (and estimable) features of television markets. Policymakers regularly turn their gaze on the industry with concerns about increasing consolidation in both the programming and distribution markets, and especially the potential for foreclosure due to vertical ownership affiliations between them. Similar concerns arise in online video markets, the development of which is (typically) outpacing research on its structure and effects.

Television is an important economic, social, political, and cultural force, and there remains much to do to improve our understanding of the economic mechanisms which govern its production. Further developing theories of television markets to reflect their multi-homing, multi-channel, and multi-product nature is one, as is better connecting empirical research to both the extant theory and any such extensions. Better understanding the effects, economic and otherwise, of public-service broadcasters is also essential, particularly as their advertising and license fee revenue come under increasing threat from economic and political forces. Building robust insights for practicing policymakers would be welcome, for both the television and online video markets as well as their interdependence. Finally, analyzing what drives the significant heterogeneity in the organization of television markets across countries and what are the consequences of these organizational differences for both economic and non-economic outcomes would be welcome. 


\section{Figures and Tables}

Table 1: US Broadcast Television Networks, 2012

\begin{tabular}{|c|c|c|c|c|c|}
\hline & $\begin{array}{r}\text { Program } \\
\text { Expn } \\
\text { (\$ million) }\end{array}$ & $\begin{array}{r}\text { Average } \\
\text { Prime } \\
\text { Time } \\
\text { Rating }\end{array}$ & $\begin{array}{c}\text { Average } \\
\text { 24-Hour } \\
\text { Rating }\end{array}$ & $\begin{array}{r}\text { Cost per } \\
\text { Thousand } \\
\text { (CPM; \$) }\end{array}$ & $\begin{array}{r}\text { Net } \\
\text { Advertising } \\
\text { Revenue } \\
\text { (\$ million) }\end{array}$ \\
\hline \multicolumn{6}{|l|}{ Big 4 B/C Networks } \\
\hline $\mathrm{ABC}$ & 2,763 & 3.9 & 2.4 & 17.6 & 3,177 \\
\hline $\mathrm{CBS}$ & 3,303 & 5.2 & 2.8 & 16.2 & 4,124 \\
\hline $\mathrm{NBC}$ & 4,041 & 4.7 & 2.6 & 18.5 & 3,955 \\
\hline FOX & 2,120 & 3.5 & 3.8 & 33.8 & 2,634 \\
\hline Total Big 4 & 12,226 & 17.4 & 11.6 & 21.5 & 13,891 \\
\hline \multicolumn{6}{|l|}{ Minor B/C Networks } \\
\hline The CW & 439 & 0.7 & 0.6 & 44.1 & 418 \\
\hline Univision & 234 & 1.7 & 0.7 & - & 641 \\
\hline Telemundo & 204 & 0.6 & 0.3 & - & 374 \\
\hline UniMÃąs & 83 & 0.3 & 0.2 & - & 160 \\
\hline Total Minor & 1,129 & 3.6 & 2.0 & - & 1,752 \\
\hline Total B/C Networks & 13,355 & 21.0 & 13.6 & - & 15,642 \\
\hline Weighted Avg B/C Networks & - & - & - & 21.6 & - \\
\hline Big-4 Share & $91.5 \%$ & $83.0 \%$ & $85.5 \%$ & - & $88.8 \%$ \\
\hline
\end{tabular}

Notes: Reported are aggregate statistics for US broadcast networks in 2012 (SNL Kagan (2014a)). Reported are measures of network costs (programming expenditure), quantity (viewership), price (advertising cost-per-thousand, or CPM), and net advertising revenue. "Rating" is the average percentage of US households watching that channel across a set time interval. US broadcast networks are divided into two groups: the "Big-Four" broadcast networks (ABC, NBC, CBS, Fox) and "minor" broadcast networks. Weighted average broadcast networks is weighted by the average 24-hour rating. Big-4 share is the share of the column spent/watched/earned by the Big-4 broadcast networks. 
Figure 1: The two-sided TV market

Advertisers

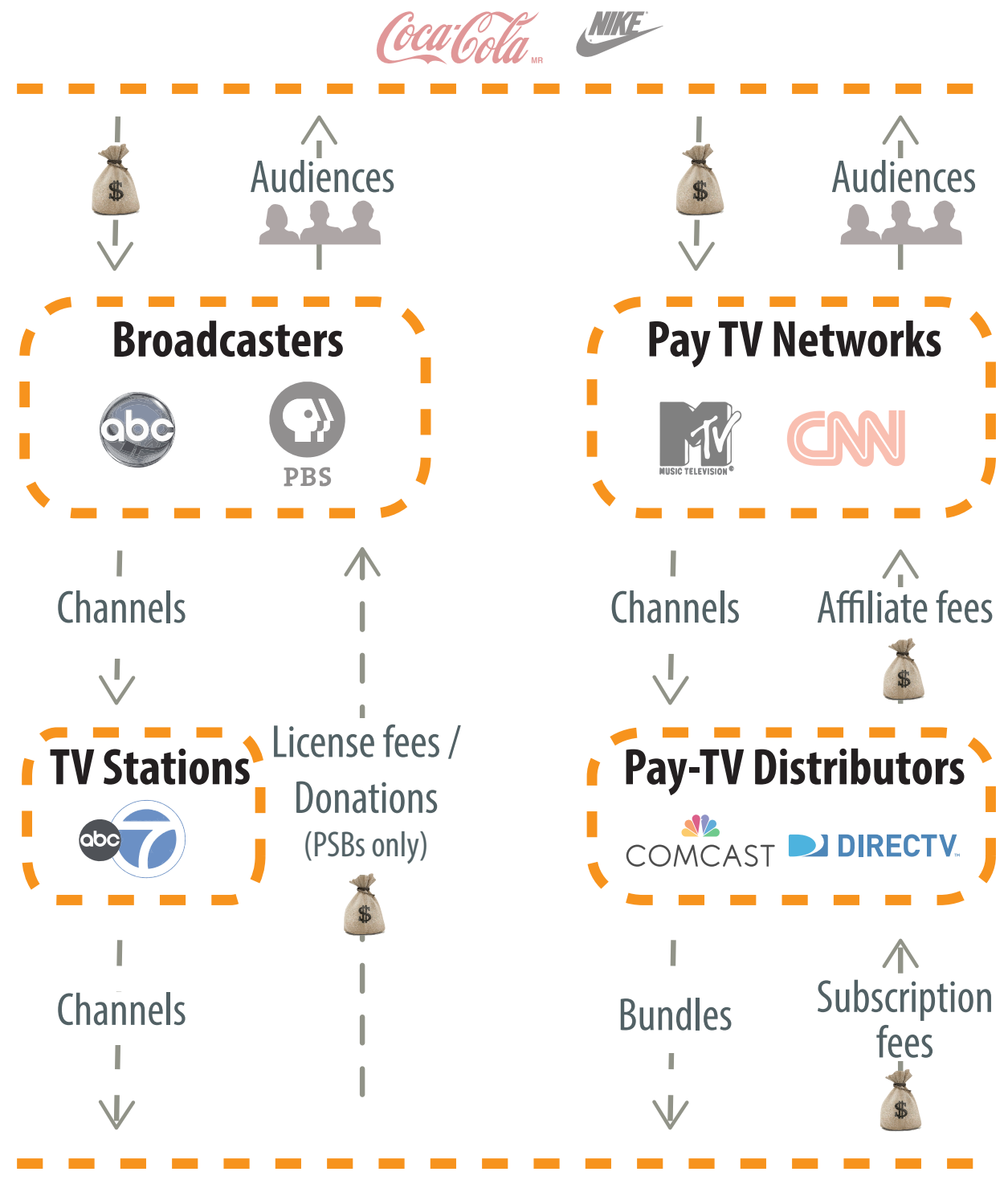

\section{Households}

Notes: Depicted is the two-sided nature of TV markets. In the left panel is the free-to-air broadcasting market and in the right panel is the pay-television market. In both markets, there is a wholesale market for programming, in which content providers (broadcaster networks, pay-tv networks) negotiate with distributors (broadcast stations, pay-tv distributors) for the right to carry their content, and a retail market for distribution, in which distributors either broadcast or set prices for access to that content to households. The majority of commercial broadcasters only earn money through the sale of audiences to advertisers. Funding for Public Service Broadcasters (PSBs) comes from mandatory household license fees, sales of advertising, and/or donations from viewers. Funding for pay-television channels and distributors con from a mix of advertising sales and subscriber payments (see Tables 1, 2, and 3). 
Figure 2: Core purposes of UK PSBs

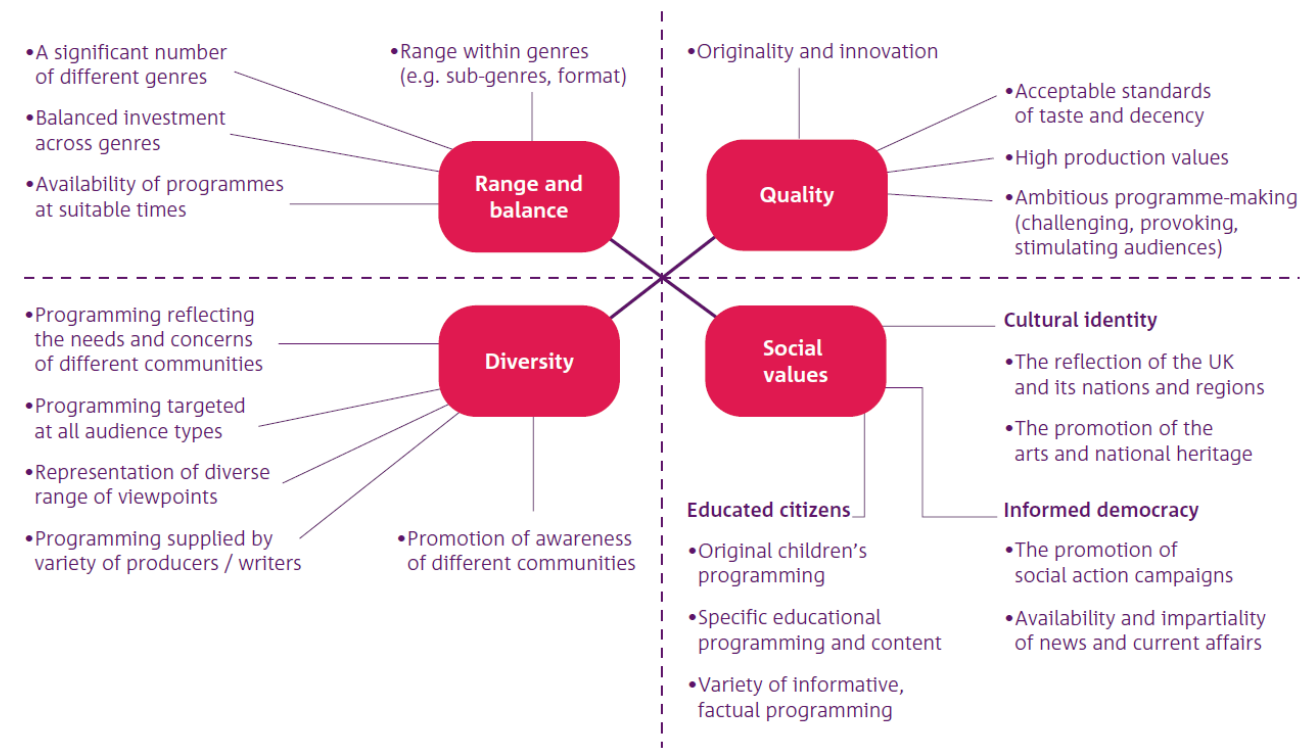

Notes: Depicted are the core purposes of the UK's Public Service Broadcasters, including the BBC, and examples of the types of programming that support these purposes, as indicated by the UK media regulator, Ofcom (Ofcom $(2004$, p26)). 
Figure 3: Public Funding for Television, 2011

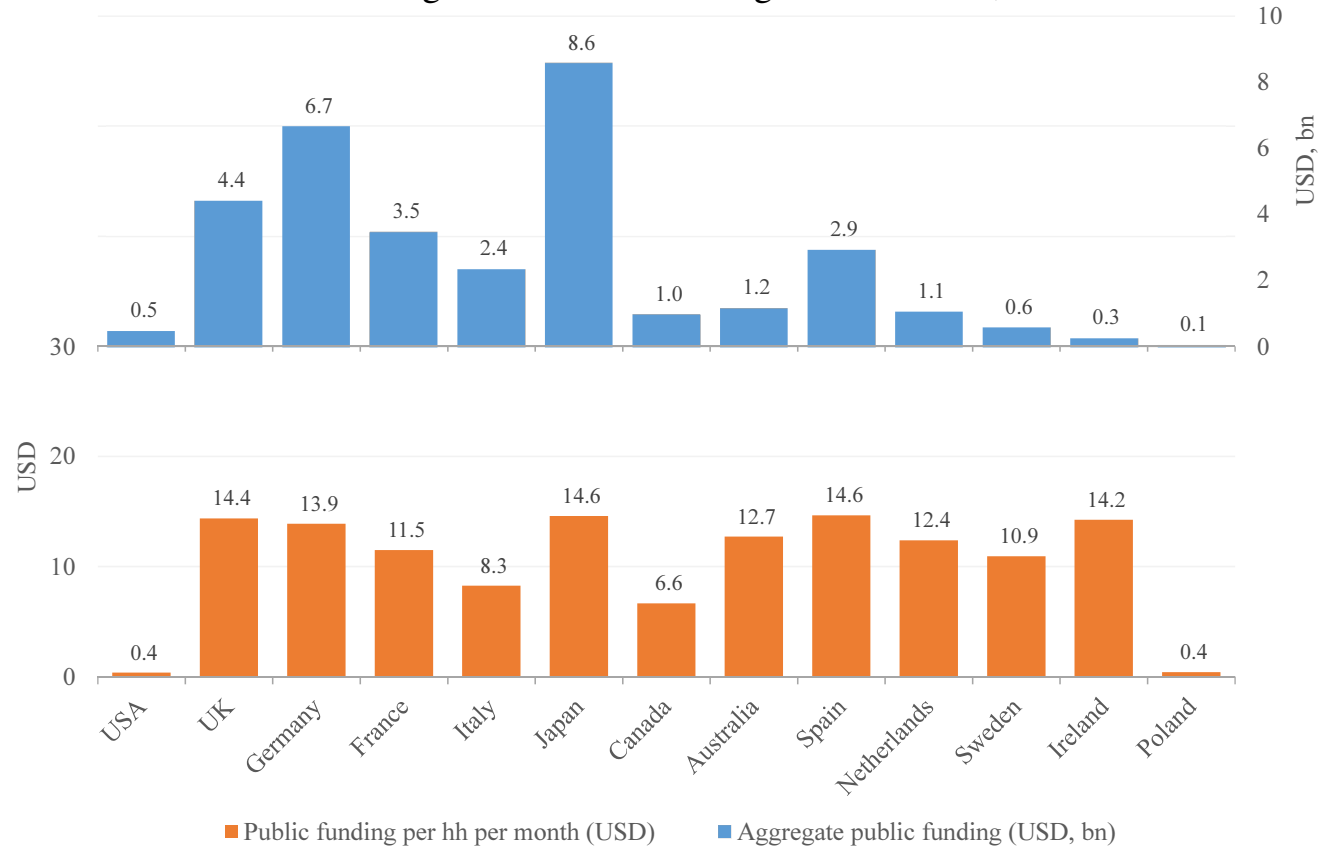

Notes: Reported is the amount of public (government) funding for television in a range of countries in the year 2011. The top panel reports aggregate funding (in \$ billion) and per-household funding (in \$ per household per month). Amounts have been converted to USD using World Bank average 2011 exchange rates. (Ofcom (2012, Figure 3.1), author calculations). 
Figure 4: US Pay Television Distributor Subscribers, 1985-2013

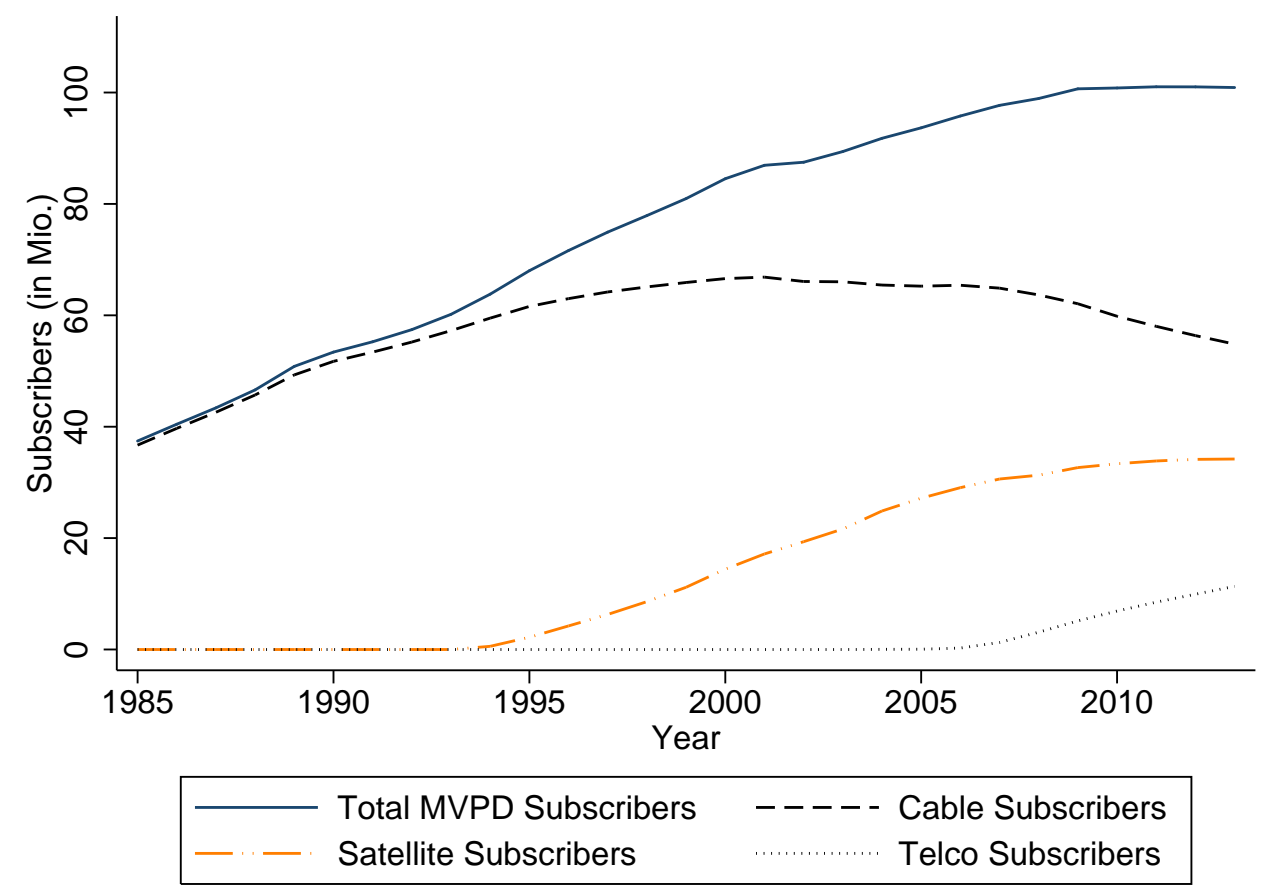

Notes: Depicted is the number of US Pay-Television subscribers (in millions) by distribution platform between 1985 and 2013 (SNL Kagan (2014a)). MVPD stands for Multi-Program Video Distributor, the FCC definition of a pay-television distributor. 
Figure 5: Distribution of Cable Prices, 2011

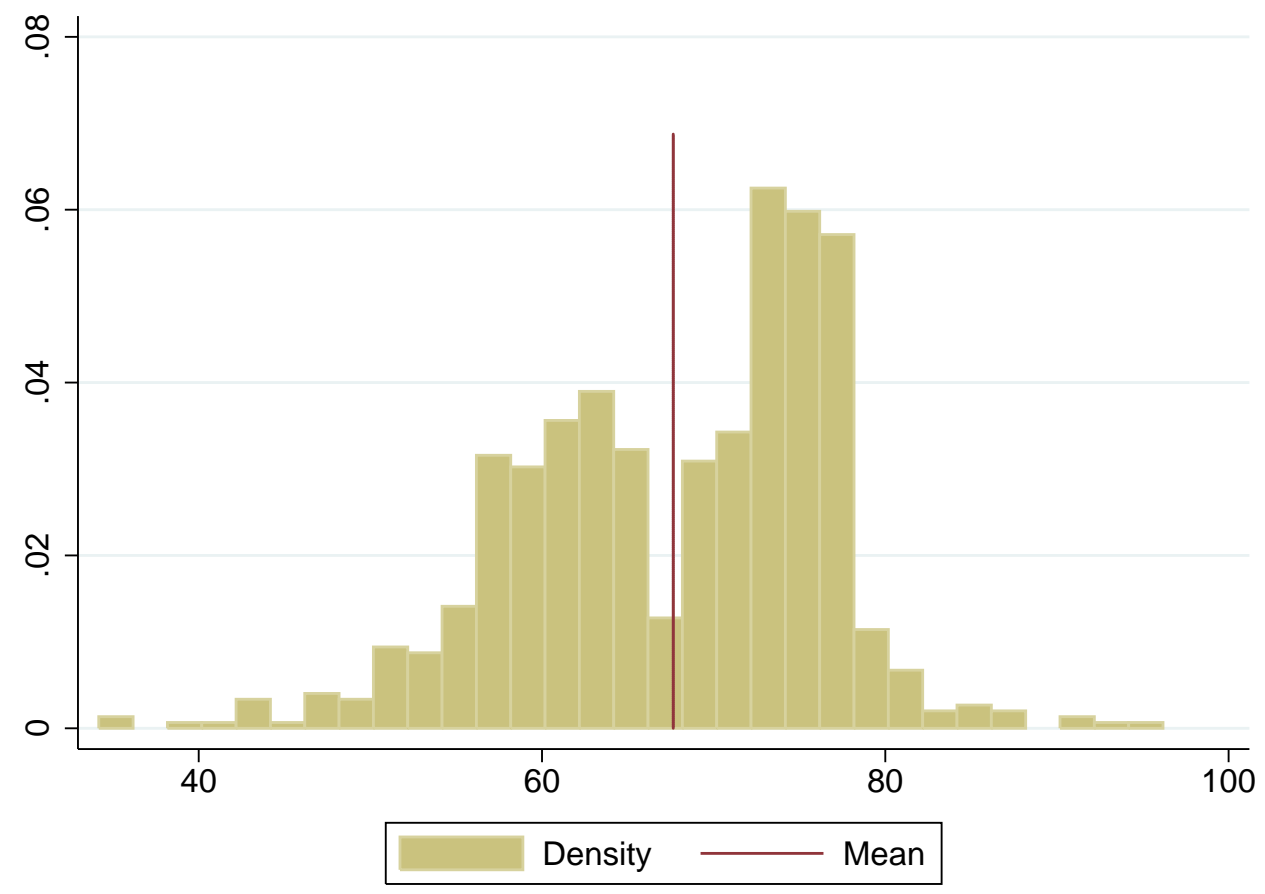

Notes: Depicted is the distribution of cable television prices as measured by average household expenditure on Basic, Expanded Basic, and Digital Basic cable services. The mean of \$67.64 is indicated in red. Source: Author calculations from FCC (2012a) 
Figure 6: MVPD (Cable + Satellite) Prices, 1983-2012

December $1983=100$

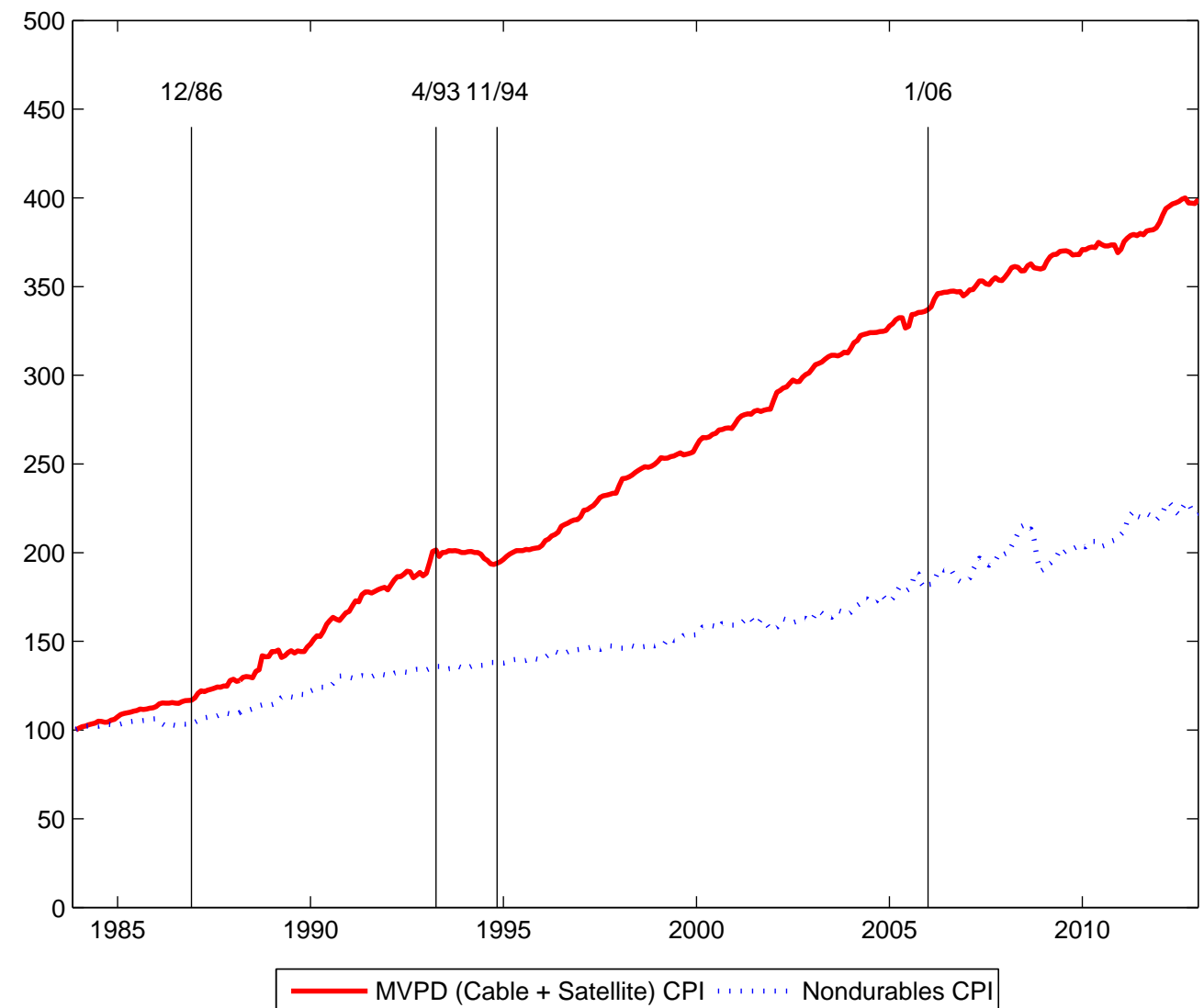

Notes: Reported are price indices from the Consumer Price Index (CPI) from December, 1983 to December, 2013 for MVPD (Multi-Program Video Distributor, i.e. cable + satellite) services as well as consumer non-durables.

Source: Bureau of Labor Statistics. 
Figure 7: Distribution of Cable Channels, 2011

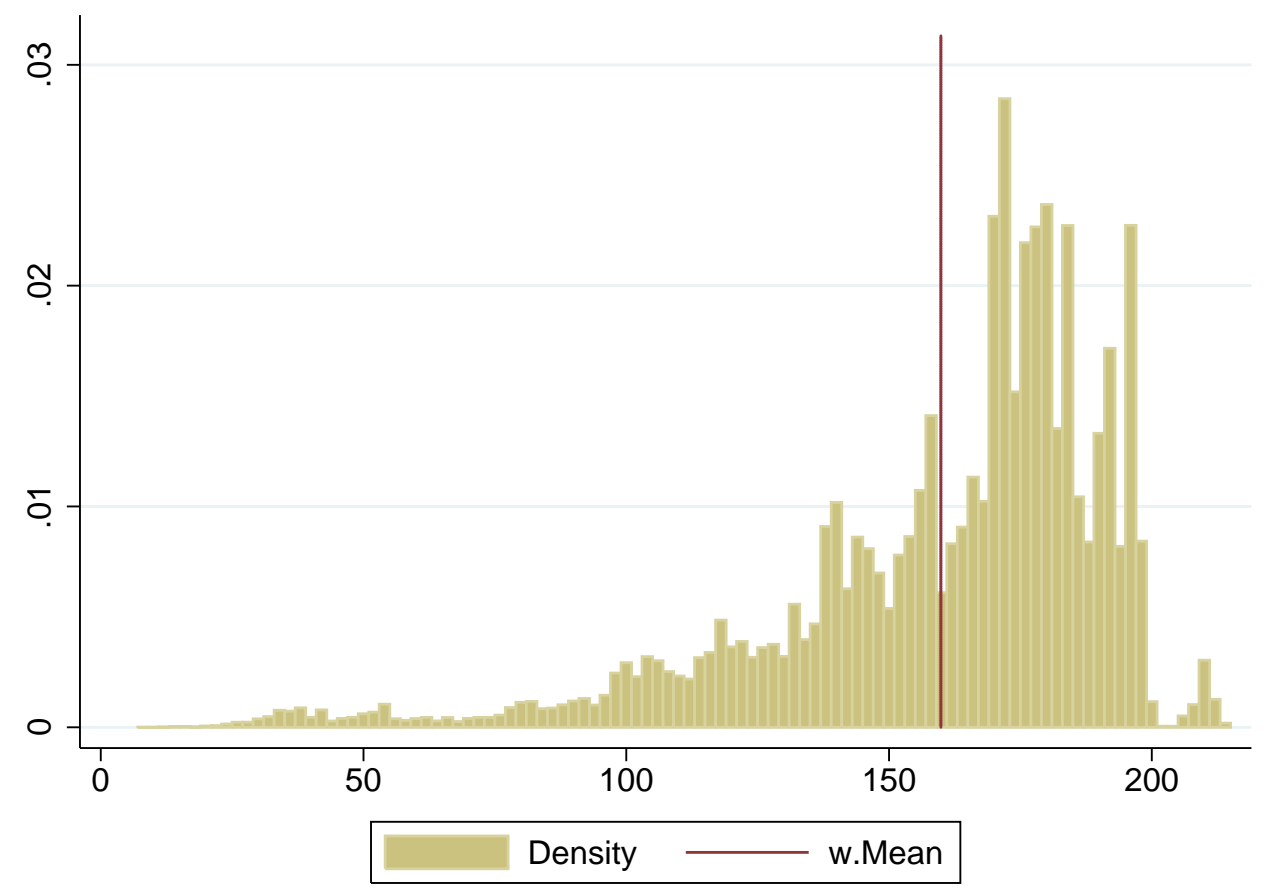

Notes: Depicted is the distribution of pay-television channels offered on Basic, Expanded Basic, and Digital Basic cable service across the 6,000 systems offering service in 2011 from the Nielsen FOCUS Database. The mean, weighted by the number of subscribers served by each system, of 159.9 is depicted in red. 
Table 2: Top-25 Cable Television Networks, 2012

\begin{tabular}{|c|c|c|c|c|c|c|c|c|c|c|}
\hline & $\begin{array}{r}\text { Prog } \\
\text { Expn } \\
(\$ \mathrm{~m})\end{array}$ & $\begin{array}{r}\text { Avg } \\
\text { Prime } \\
\text { Time } \\
\text { Rating }\end{array}$ & $\begin{array}{r}\text { Avg } \\
24 h \\
\text { Rating }\end{array}$ & $\begin{array}{r}\text { CPM } \\
(\$)\end{array}$ & $\begin{array}{r}\text { Net } \\
\text { Advert } \\
\text { Rev }\end{array}$ & Subs & $\begin{array}{r}\text { Avg } \\
\text { Affil } \\
\text { Fee }\end{array}$ & $\begin{array}{r}\text { Affiliate } \\
\text { Rev } \\
(\$ \mathrm{~m})\end{array}$ & $\begin{array}{r}\text { Total } \\
\text { Rev } \\
(\$ \mathbf{m})\end{array}$ & $\begin{array}{r}\text { Fee } \\
\text { Rev } \\
\text { Share }\end{array}$ \\
\hline \multicolumn{11}{|l|}{ Cable Networks } \\
\hline ESPN & 5,333 & 一 & 0.78 & 19.3 & 1,770 & 98.5 & 5.04 & 5,973 & 7,742 & 0.77 \\
\hline TNT & 1,160 & 一 & 0.83 & 8.8 & 968 & 99.7 & 1.20 & 1,443 & 2,411 & 0.60 \\
\hline Nickelodeon/Nick At Nite & 429 & - & 1.13 & 6.6 & 931 & 99.2 & 0.55 & 657 & 1,589 & 0.41 \\
\hline USA & 759 & 一 & 1.02 & 6.9 & 1,043 & 99.0 & 0.68 & 815 & 1,858 & 0.44 \\
\hline FOX News & 607 & - & 0.92 & 5.0 & 742 & 97.8 & 0.89 & 1,040 & 1,782 & 0.58 \\
\hline TBS & 607 & 一 & 0.64 & 10.4 & 895 & 99.7 & 0.56 & 673 & 1,568 & 0.43 \\
\hline Disney Channel & 306 & - & 1.28 & - & - & - & 1.09 & - & - & - \\
\hline MTV & 579 & 一 & 0.39 & 13.1 & 817 & 98.1 & 0.40 & 476 & 1,294 & 0.37 \\
\hline $\mathrm{CNN}$ & 311 & - & 0.32 & 6.2 & 328 & 98.9 & 0.58 & 686 & 1,014 & 0.68 \\
\hline FX Network & 460 & - & 0.55 & 8.9 & 509 & 97.9 & 0.48 & 566 & 1,075 & 0.53 \\
\hline ESPN2 & 496 & - & 0.22 & 10.4 & 270 & 98.5 & 0.67 & 792 & 1,062 & 0.75 \\
\hline Discovery Channel & 171 & - & 0.43 & 10.9 & 526 & 99.1 & 0.35 & 420 & 946 & 0.44 \\
\hline Lifetime Television & 418 & 一 & 0.43 & 8.0 & 505 & 99.5 & 0.31 & 366 & 872 & 0.42 \\
\hline Food Network & 278 & 一 & 0.48 & 9.8 & 609 & 99.4 & 0.18 & 218 & 826 & 0.26 \\
\hline$A \& E$ & 397 & 一 & 0.60 & 5.3 & 469 & 98.7 & 0.28 & 334 & 804 & 0.42 \\
\hline History & 302 & 一 & 0.72 & 4.7 & 497 & 98.6 & 0.25 & 291 & 788 & 0.37 \\
\hline HGTV & 257 & 一 & 0.56 & 7.2 & 589 & 98.7 & 0.16 & 184 & 773 & 0.24 \\
\hline NFL Network & 1,078 & - & 0.19 & 9.0 & 129 & 68.8 & 0.85 & 645 & 774 & 0.83 \\
\hline Cartoon Network & 250 & - & 0.87 & 4.5 & 462 & 98.9 & 0.20 & 237 & 699 & 0.34 \\
\hline ABC Family Channel & 280 & - & 0.48 & 8.4 & 445 & 97.0 & 0.26 & 298 & 743 & 0.40 \\
\hline Syfy & 284 & - & 0.42 & 7.8 & 426 & 98.0 & 0.27 & 312 & 739 & 0.42 \\
\hline Comedy Central & 290 & 一 & 0.38 & 9.3 & 457 & 98.3 & 0.17 & 201 & 657 & 0.31 \\
\hline AMC & 214 & 一 & 0.46 & 7.0 & 362 & 98.9 & 0.29 & 324 & 686 & 0.47 \\
\hline $\mathrm{CNBC}$ & 209 & 一 & 0.15 & 9.5 & 223 & 96.8 & 0.30 & 356 & 579 & 0.62 \\
\hline Bravo & 268 & - & 0.31 & 11.8 & 342 & 94.8 & 0.23 & 262 & 604 & 0.43 \\
\hline $\begin{array}{l}\text { Total Top-25 } \\
\text { Average Top-25 }\end{array}$ & 15,746 & - & 14.56 & 7.6 & 14,314 & 97.2 & 16.23 & 18,864 & 33,178 & 0.57 \\
\hline $\begin{array}{l}\text { Total Cable (198 networks) } \\
\text { Average Cable }\end{array}$ & 24,066 & - & 30.10 & 6.3 & 21,623 & 46.2 & 41.85 & 28,361 & 49,984 & 0.57 \\
\hline Top-25 Share & $65.4 \%$ & - & $48.4 \%$ & & $66.2 \%$ & & $38.8 \%$ & $66.5 \%$ & $66.4 \%$ & \\
\hline
\end{tabular}

Notes: Reported are aggregate statistics for the largest US pay-television networks in 2012 for which data are available from SNL Kagan (2014a). Reported are measures of network costs (programming expenditure), quantity (viewership and subscribers), price (advertising cost-per-thousand, or CPM, and affiliate fees, if any), and revenue, as well as the relative importance of advertising versus fee revenue in each channel's total. Affiliate fees are \$ per household per month. Reported here is information for the top- 25 most widely available cable networks, as well as totals for all 198 cable networks for which information is available from SNL Kagan. Top-25 Share is the share of the column spent/watched/earned by the Top-25 listed broadcast networks. See also Table 3 for information about Regional Sports and Premium Networks. 
Table 3: Regional Sports Networks and Premium Networks, 2012

\begin{tabular}{|c|c|c|c|c|c|c|c|}
\hline & $\begin{array}{r}\text { Program } \\
\text { Expn }\end{array}$ & $\begin{array}{r}\text { Net } \\
\text { Advert } \\
\text { Revenue }\end{array}$ & Subs & $\begin{array}{r}\text { Average } \\
\text { Affiliate } \\
\text { Fee }\end{array}$ & $\begin{array}{r}\text { Affiliate } \\
\text { Fee } \\
\text { Revenue }\end{array}$ & $\begin{array}{r}\text { Total } \\
\text { Revenue }\end{array}$ & $\begin{array}{r}\text { Affiliate } \\
\text { Revenue } \\
\text { Share }\end{array}$ \\
\hline \multicolumn{8}{|l|}{ Regional Sports Networks (RSNs) } \\
\hline Fox Sports RSNs & 1,483 & 237 & 18.8 & 2.66 & 1,782 & 2,049 & 0.87 \\
\hline Comcast SportsNet RSNs & 758 & 140 & 10.5 & 2.79 & 833 & 986 & 0.84 \\
\hline Yankees Entertainment (YES) & 252 & 67 & 6.0 & 2.99 & 433 & 510 & 0.85 \\
\hline Root Sports RSNs & 243 & 58 & 3.6 & 2.81 & 284 & 346 & 0.82 \\
\hline Madison Square Garden Network & 103 & 61 & 4.3 & 2.71 & 263 & 336 & 0.78 \\
\hline SportsNet New York & 214 & 38 & 3.8 & 2.55 & 219 & 258 & 0.85 \\
\hline MSG Plus & 90 & 24 & 4.3 & 2.38 & 224 & 252 & 0.89 \\
\hline Sun Sports & 168 & 21 & 3.7 & 2.69 & 207 & 230 & 0.90 \\
\hline New England Sports Network & 151 & 31 & 2.1 & 3.62 & 178 & 213 & 0.83 \\
\hline Prime Ticket & 144 & 24 & 3.1 & 2.36 & 169 & 198 & 0.85 \\
\hline Mid-Atlantic Sports Network & 138 & 27 & 1.9 & 2.14 & 138 & 168 & 0.82 \\
\hline SportSouth & 55 & 19 & 1.3 & 0.62 & 65 & 86 & 0.76 \\
\hline SportsTime Ohio & 60 & 13 & 1.2 & 1.85 & 65 & 80 & 0.81 \\
\hline Altitude Sports \& Entertainment & 52 & 15 & 0.7 & 1.57 & 56 & 73 & 0.77 \\
\hline Time Warner Cable SportsNet/Deportes & 40 & 6 & 3.0 & 2.98 & 42 & 49 & 0.86 \\
\hline Comcast/Charter Sports Southeast & 28 & 3 & 0.0 & 0.57 & 38 & 42 & 0.91 \\
\hline Cox Sports Television & 18 & 8 & 0.6 & 0.74 & 16 & 24 & 0.66 \\
\hline Channel 4 San Diego & 5 & 1 & 0.8 & 0.80 & 8 & 9 & 0.87 \\
\hline Longhorn Network & 23 & 1 & 2.7 & 0.27 & 6 & 8 & 0.83 \\
\hline Total RSNs & 4,025 & 793 & 72.3 & & 5,026 & 5,916 & \\
\hline Average RSNs & & & 1.8 & 2.41 & & & 0.85 \\
\hline \multicolumn{8}{|l|}{ Premium Networks } \\
\hline HBO / Cinemax & 1,632 & 0 & 41.5 & 7.68 & 3,732 & 4,415 & 1.00 \\
\hline Showtime / TMC / Flix & 595 & 0 & 76.1 & 1.64 & 1,473 & 1,564 & 1.00 \\
\hline Starz / Encore & 661 & 0 & 56.1 & 1.93 & 1,259 & 1,310 & 1.00 \\
\hline EPIX / EPIX Drive-In & 217 & 0 & 9.9 & 1.77 & 206 & 341 & 1.00 \\
\hline Total Premium & 3,105 & 0 & & 13.01 & 6,670 & 7,630 & \\
\hline Average Premium & & & 45.9 & 3.10 & & & 1.00 \\
\hline
\end{tabular}

Notes: Reported are aggregate statistics for the largest US pay-television networks in 2012 for which data are available from SNL Kagan (2014a). Reported are measures of network costs (programming expenditure), quantity (subscribers), price (affiliate fees), and revenue, as well as the relative importance of advertising versus fee revenue in each channel's total. Reported here is information on 40 Regional Sports Networks (RSNs), with the 13 Fox Sports, 8 Comcast SportsNet, and 3 Root Sports reported as single groups, and Premium Networks. See also Table 2 for information about the largest "cable television networks". 
Figure 8: Relative importance of video platform across selected countries (\% of TV HH), 2011

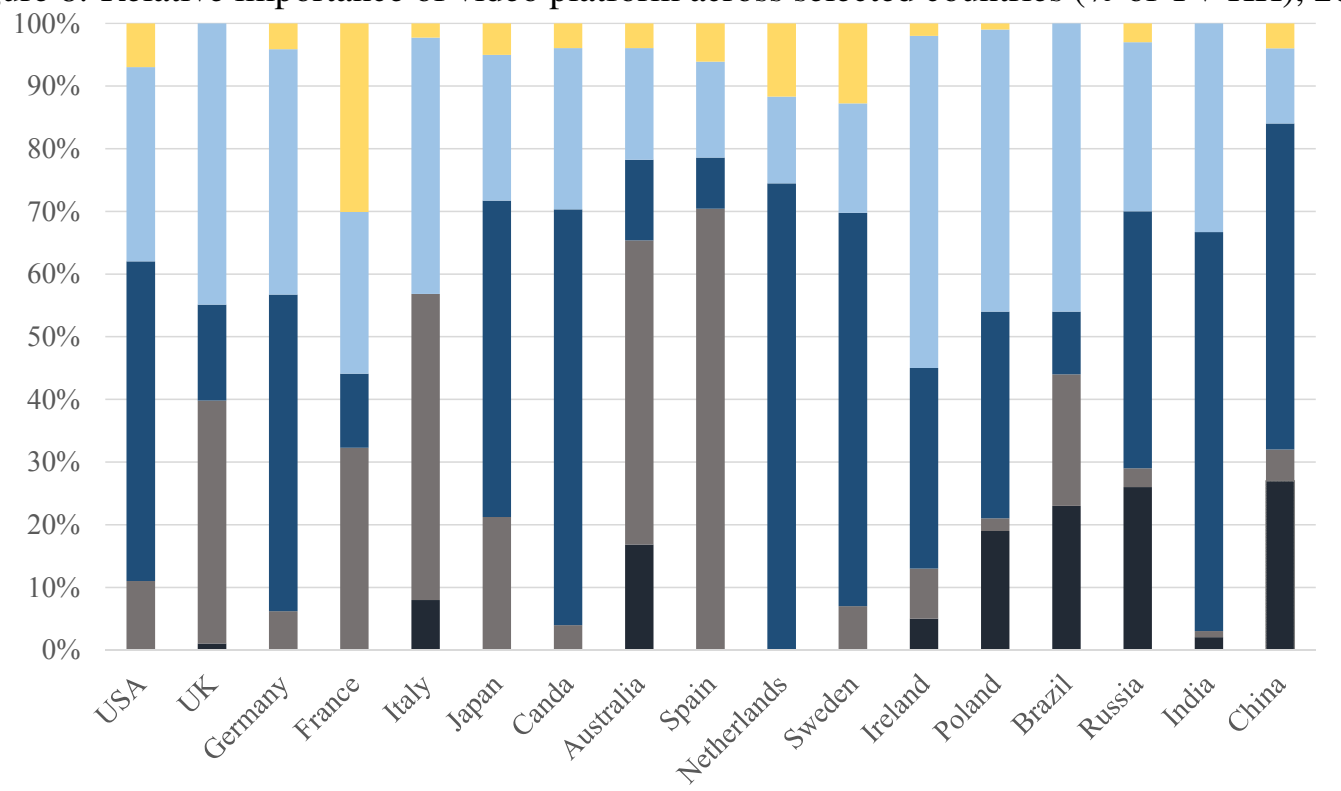

- Broadcast $\square$ DTT $\square$ Cable $\square$ Satellite Telco

Notes: Depicted is the share of TV households across a range of countries in 2011 that

obtain video service by each of five platforms: (analog) broadcast, digital broadcast (DTT), cable, satellite, and telco (IPTV).

Source: Ofcom (2012, Figure 3.28) 
Figure 9: International comparison of pay-TV versus free TV (\% of TV HH), 2011

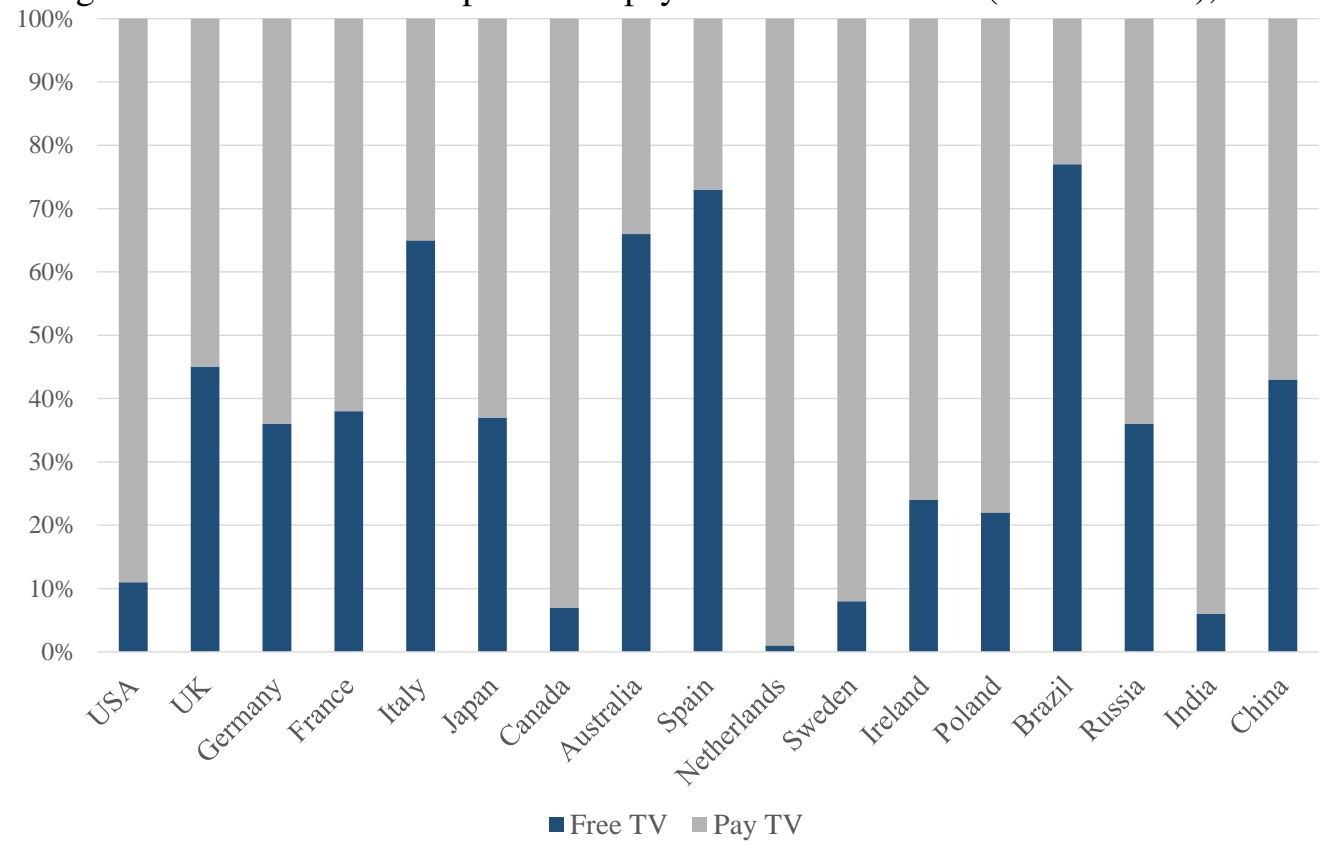

Notes: Depicted is the share of TV households served by free versus pay platforms across a range of countries in 2011

Source: Ofcom (2012, Figure 3.34) 
Table 4: TV Industry Statistics Across Selected Countries, 2011

\begin{tabular}{|c|c|c|c|c|c|c|c|c|c|c|c|}
\hline & $\begin{array}{c}\text { North } \\
\text { America }\end{array}$ & \multicolumn{6}{|c|}{ Western Europe } & \multicolumn{3}{|c|}{ Asia } & \multirow{2}{*}{$\begin{array}{c}\text { Latin } \\
\text { America } \\
\text { Brazil }\end{array}$} \\
\hline & USA & UK & Germany & France & Italy & Sweden & Poland & Japan & Russia & India & \\
\hline \multicolumn{12}{|l|}{ Households (HHs) } \\
\hline Total HHs & 118.6 & 26.4 & 40.4 & 27.6 & 24.4 & 4.5 & 14.3 & 49.3 & 52.7 & 229.3 & 62.5 \\
\hline Television HHs & 117.4 & 25.7 & 38.3 & 27.0 & 24.2 & 4.4 & 12.9 & 49.2 & 50.4 & 140.2 & 61.3 \\
\hline \multicolumn{12}{|l|}{ Subscribers } \\
\hline Free-to-air "Subs" & 18.4 & 19.8 & 15.8 & 15.0 & 19.1 & 1.0 & 1.5 & 43.5 & 26.1 & 12.5 & 45.3 \\
\hline Pay Subs & 100.4 & 14.3 & 22.6 & 19.9 & 5.1 & 3.4 & 11.8 & 14.1 & 24.3 & 129.7 & 16.0 \\
\hline \multicolumn{12}{|l|}{ Viewing } \\
\hline Hours per day & 4.9 & 4.0 & 3.8 & 3.8 & 4.2 & 2.7 & 4.0 & - & 3.7 & 2.0 & 2.7 \\
\hline \multicolumn{12}{|l|}{ Subscription Cost } \\
\hline Monthly ARPU & $\$ 83.01$ & $\$ 48.39$ & $\$ 20.99$ & $\$ 39.97$ & $\$ 37.96$ & $\$ 27.13$ & $\$ 18.71$ & $\$ 47.59$ & $\$ 3.34$ & $\$ 3.74$ & $\$ 53.60$ \\
\hline \multicolumn{12}{|l|}{ TV Industry Revenue } \\
\hline Aggregate TV Rev & 160.4 & 18.1 & 18.6 & 16.4 & 12.5 & 2.9 & 3.8 & 49.9 & 5.8 & 8.8 & 19.9 \\
\hline Subscription & 102.2 & 8.1 & 6.3 & 8.1 & 3.9 & 1.4 & 2.5 & 18.5 & 1.3 & 6.1 & 8.0 \\
\hline Advertising & 57.8 & 5.7 & 5.7 & 4.9 & 6.2 & 0.9 & 1.3 & 22.7 & 4.5 & 2.4 & 11.5 \\
\hline Public Funding & 0.5 & 4.3 & 6.6 & 3.5 & 2.3 & 0.6 & 0.1 & 8.7 & 0.0 & 0.3 & 0.4 \\
\hline Monthly Per-HH Rev & $\$ 112.73$ & $\$ 57.31$ & $\$ 38.36$ & $\$ 49.44$ & $\$ 42.75$ & $\$ 53.02$ & $\$ 22.44$ & $\$ 84.35$ & $\$ 9.13$ & $\$ 3.21$ & $\$ 26.51$ \\
\hline Subscription & $\$ 71.80$ & $\$ 25.66$ & $\$ 13.00$ & $\$ 24.33$ & $\$ 13.37$ & $\$ 25.62$ & $\$ 14.58$ & $\$ 31.33$ & $\$ 2.13$ & $\$ 2.23$ & $\$ 10.71$ \\
\hline Advertising & $\$ 40.59$ & $\$ 18.00$ & $\$ 11.67$ & $\$ 14.69$ & $\$ 21.26$ & $\$ 16.20$ & $\$ 7.39$ & $\$ 38.41$ & $\$ 7.05$ & $\$ 0.86$ & $\$ 15.28$ \\
\hline Public Funding & $\$ 0.34$ & $\$ 13.74$ & $\$ 13.69$ & $\$ 10.47$ & $\$ 8.00$ & $\$ 11.19$ & $\$ 0.37$ & $\$ 14.67$ & $\$ 0.03$ & $\$ 0.12$ & $\$ 0.58$ \\
\hline \multicolumn{12}{|l|}{$\%$ from each source } \\
\hline Subscription & 63.7 & 44.8 & 33.9 & 49.2 & 31.3 & 48.3 & 65.0 & 37.1 & 23.3 & 69.6 & 40.4 \\
\hline Advertising & 36.0 & 31.4 & 30.4 & 29.7 & 49.7 & 30.6 & 32.9 & 45.5 & 77.2 & 26.7 & 57.7 \\
\hline Public Funding & 0.3 & 24.0 & 35.7 & 21.2 & 18.7 & 21.1 & 1.7 & 17.4 & 0.3 & 3.8 & 2.2 \\
\hline
\end{tabular}

Notes: Reported are aggregate statistics about the television industry for a selection of countries in 2011. Households and subscribers are measured in millions. Total free-to-air and pay subscribers can exceed TV households due to multiple subscriptions per household. ARPU 三 “Average Revenue per Unit," measured in US dollars per subscribing household per month, is a common industry metric measuring the average household expenditure on pay television services. Aggregate TV industry revenue is measured in \$ billions. Monthly per-household revenue is measured in US dollars per household per month.

Source: SNL Kagan (2014a), Ofcom (2012). 


\section{Figure 10: TV Industry Revenue over Time}

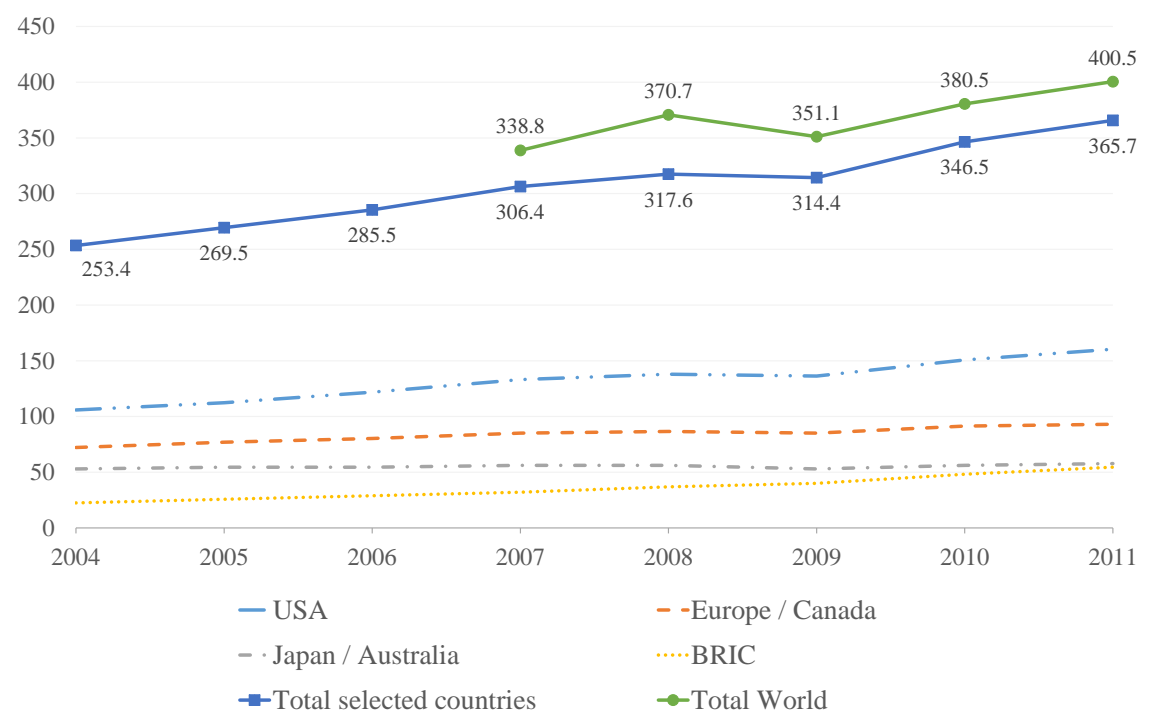

Notes: Depicted is the estimated TV industry revenue of different regions of the world, the total of these regions, and the world total between 2014 and 2011 .

Source: Ofcom (2012, Figure 3.15), PriceWaterhouseCoopers (2012, p57) 
Figure 11: Media Share of U.S. Advertising, 1949-2009

\section{MEDIA SHARE OF U.5. ADVERTISING (1949-2009)}

Share of total

$\square$ Newspapers $\quad \square$ TV and Cable $\quad$ Radio Internet

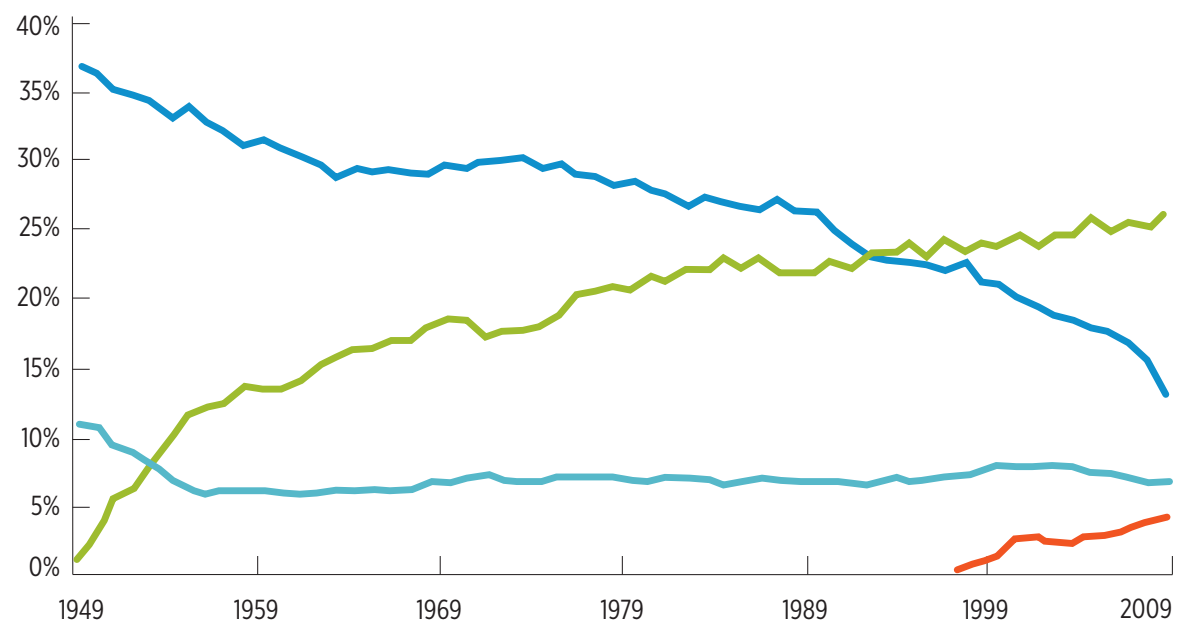

Source: Martin Langeveld at Nieman Journalism Lab; data from NAA, TVB, IAB, McCann

Notes: Depicted is the share of US advertising revenue by media type between 1949 and 2009 .

Source: FCC (2011a) 
Figure 12: US Programming Market Revenue by Channel Type, 1989-2013

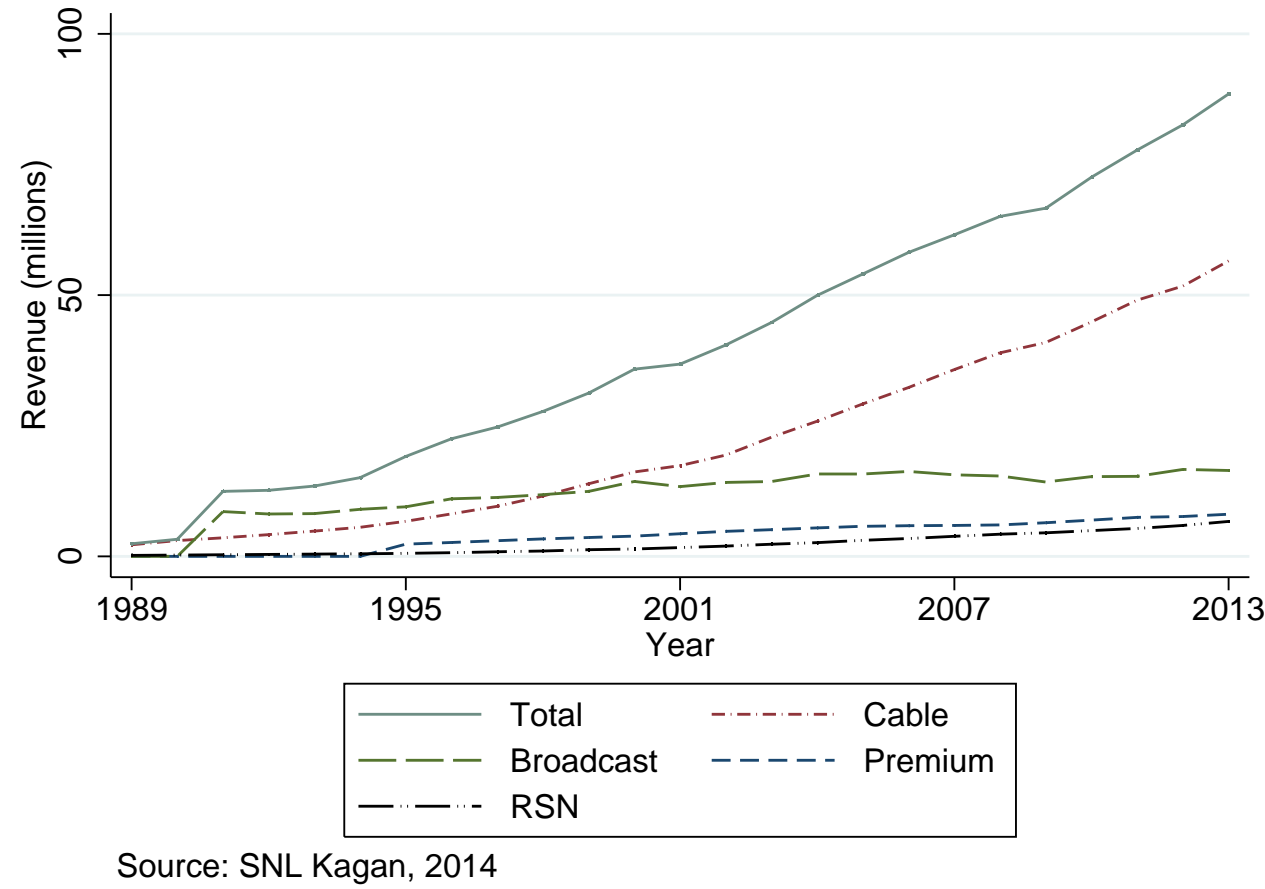

Notes: Depicted is the revenue accruing to four different types of programming networks (channels) in the television programming market between 1989 and 2013: Broadcast, Cable, Regional Sports Network, and Premium Networks. See also Tables 1. 2 and 3 for further details about revenue for these networks in 2012.

Source: SNL Kagan (2014a) 
Figure 13: US Programming Market Revenue by Source, 1989-2013

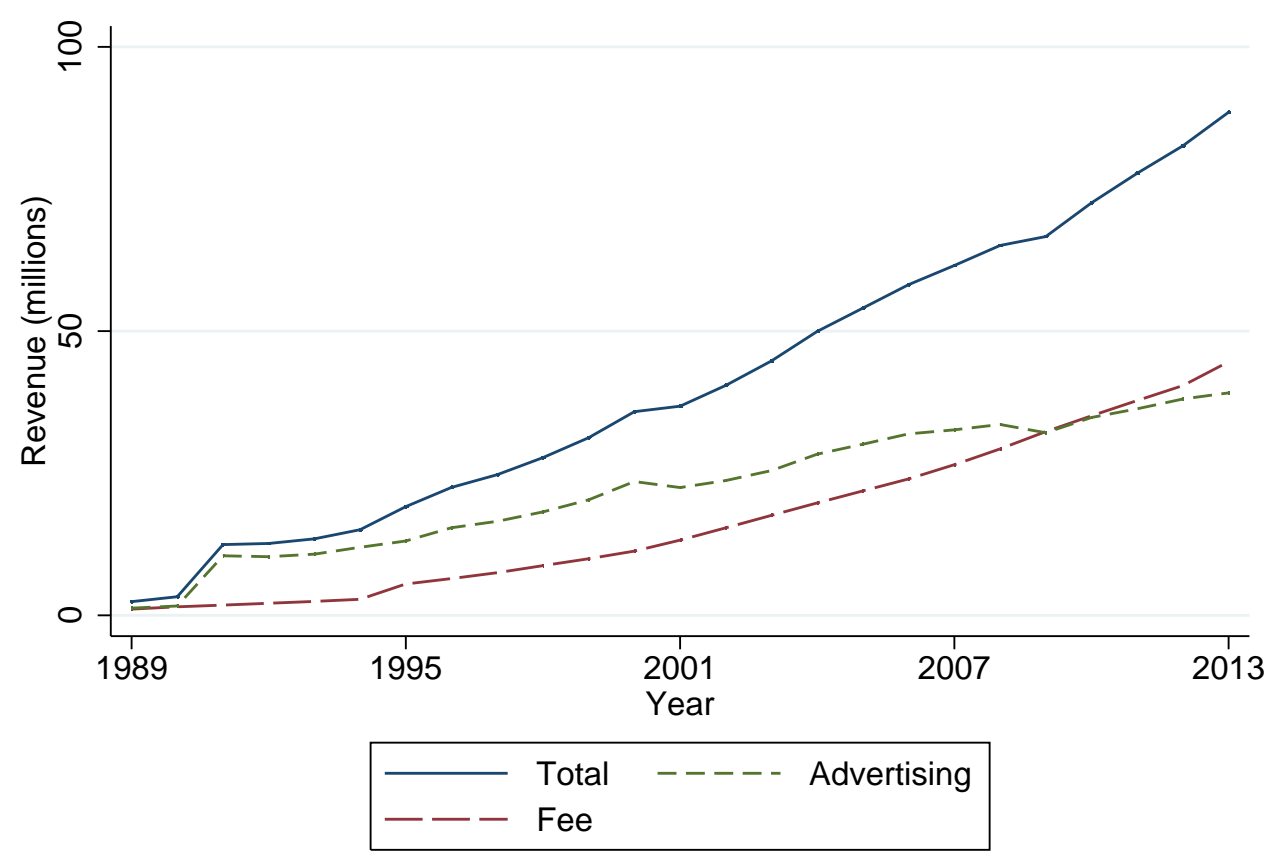

Source: SNL Kagan, 2014

Notes: Depicted is the revenue of programming networks (channels) arising from advertising versus affiliate fees in the television programming market between 1989 and 2013. See also Tables 1 . 2 and 3 for a breakdown by channel and channel type of revenue sources in 2012.

Source: SNL Kagan (2014a) 
Figure 14: Total Programming Expenditure by Prog. Type, 1989-2013

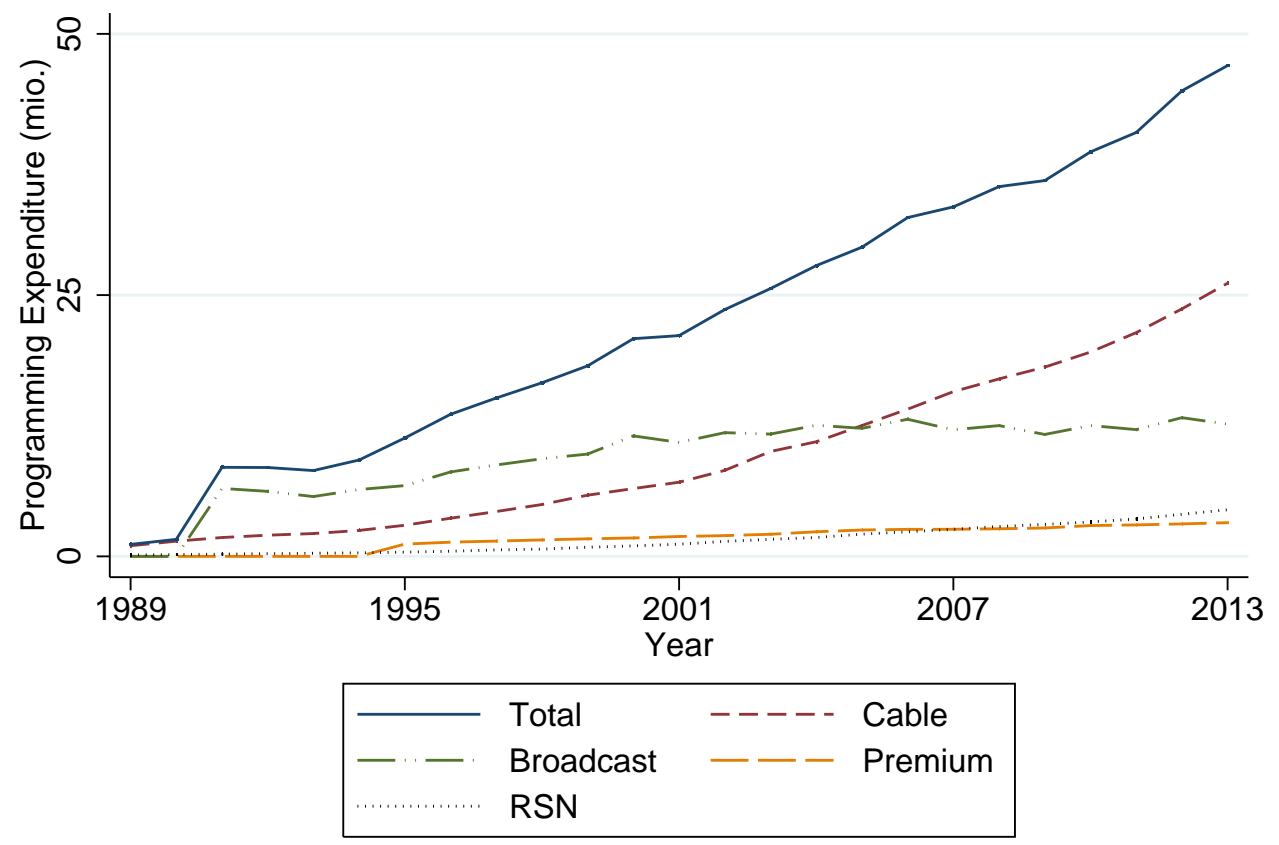

Source: SNL Kagan, 2014

Notes: Depicted is the expenditures on programming paid by four different types of programming networks (channels) in the television programming market between 1989 and 2013: Broadcast, Cable, Regional Sports Network, and Premium Networks. See also Tables 1.2 and 3 for further details about expenditures by these networks in 2012 .

Source: SNL Kagan (2014a) 
Figure 15: Total Avg Affiliate Fees per Month, 1989-2013

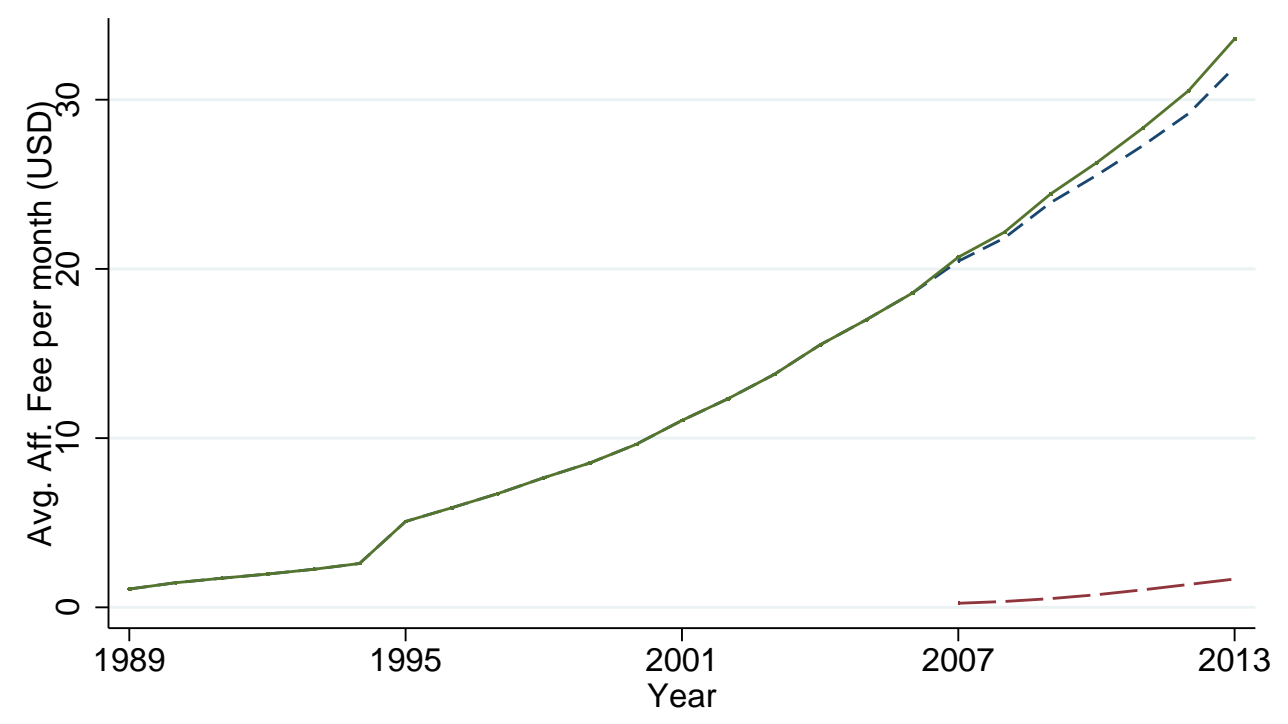

$----\quad$ Avg Cable Aff Fee per Month - - - Avg Retrans Fee per Month Total Aff Fee per Month

Source: SNL Kagan, 2014, Pew State of the Media, 2013

Notes: Depicted are the total affiliate fees paid by pay-television distributors between 1989 and 2013. See also Tables 1, 2, and 3 for further details about average affiliate fees by channel type and channel in 2012.

Source: SNL Kagan (2014a) 
Figure 16: Total Ratings by Platform Type, 1994-2012

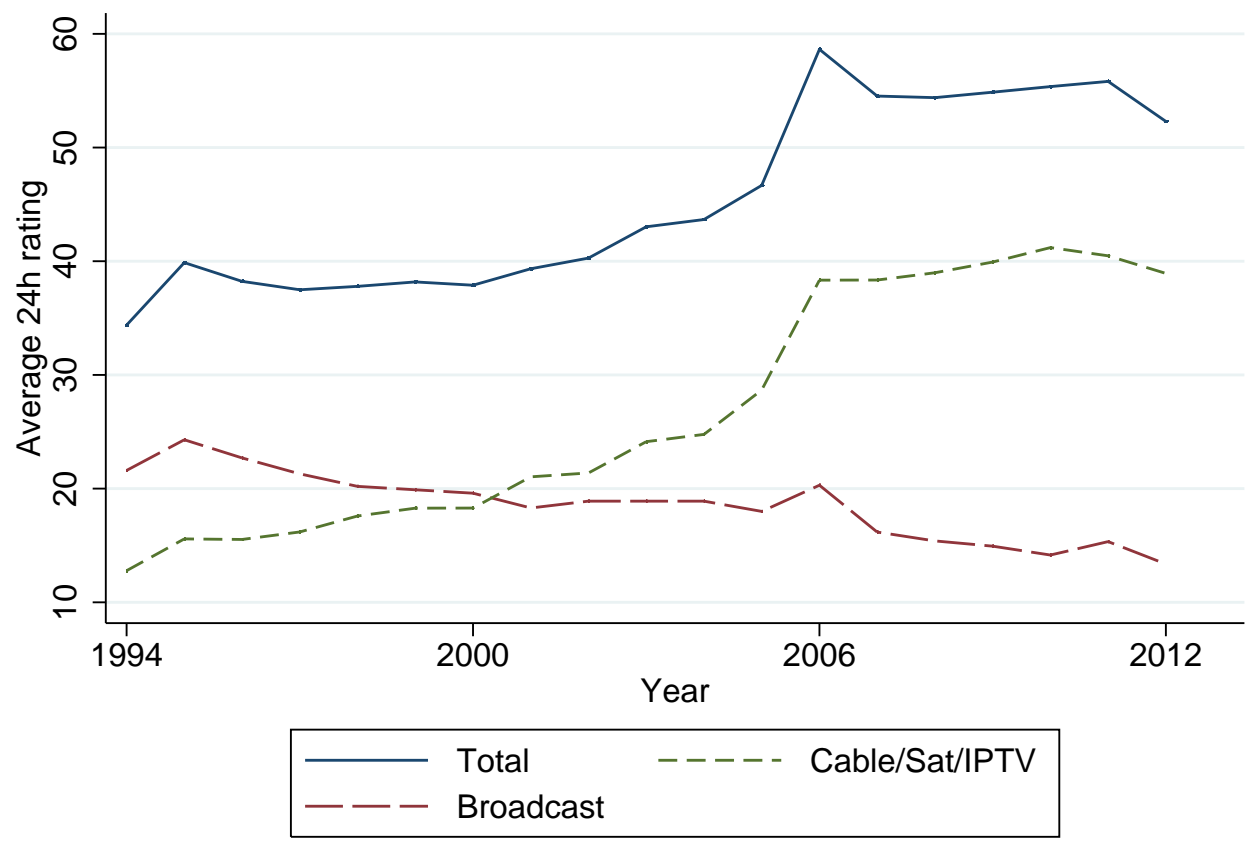

Source: SNL Kagan, 2014

Notes: Depicted is the total average 24-hour rating of broadcast and pay-television networks 1994 and 2012. See also Tables 1 and 2 for further information about average 24-hour ratings by channel type and channel for broadcast and pay-television networks in 2012.

Source: SNL Kagan (2014a) 
Figure 17: Concentration in the Upstream Market, 2013

\section{Revenue US TV Channels by Owner (2013)}

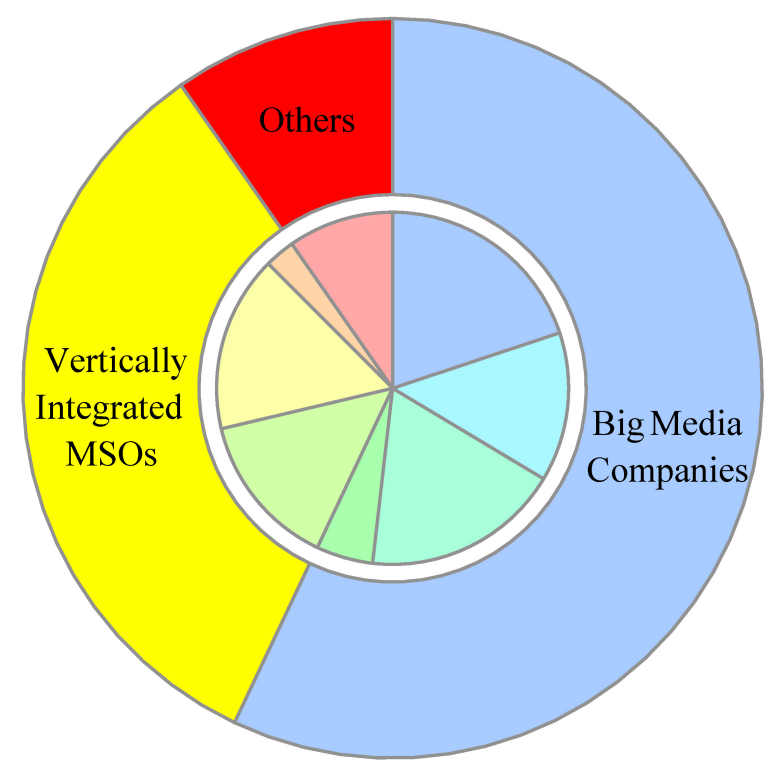

$\square$ Disney

Fox

Viacom/CBS

Liberty

Comcast

Time Warner

Cablevision

Others

Notes: Depicted is the revenue share of eight groups of owners of broadcast and pay-television programming networks in 2013: "Big Media" companies, Disney, Fox, Viacom/CBS, and Liberty, vertically integrated (cable) Multiple System Operators (MSOs), Comcast, Time Warner, and Cablevision, and Others. Revenue data is from SNL Kagan (2014a); see Table 5 and the notes there for further details. 
Table 5: Concentration in the Upstream (Channel) Market, 2013

\begin{tabular}{|c|c|c|c|c|c|}
\hline $\begin{array}{l}\text { Big Media } \\
\text { Companies }\end{array}$ & $\begin{array}{l}\text { Total Rev. } \\
\text { (\$ million) }\end{array}$ & $\begin{array}{r}\text { Ownership } \\
\text { Share }\end{array}$ & $\begin{array}{l}\text { Vertically Integrated } \\
\text { MSOs }\end{array}$ & $\begin{array}{l}\text { Total Rev. } \\
\text { (\$ million) }\end{array}$ & $\begin{array}{r}\text { Ownership } \\
\text { Share }\end{array}$ \\
\hline The Walt Disney Co. & & & Comcast Corporation & & \\
\hline $\mathrm{ABC}$ & 3,161 & $100 \%$ & NBC & 3,095 & $100 \%$ \\
\hline ESPN & 8,343 & $80 \%$ & Telemundo & 396 & $100 \%$ \\
\hline Disney Channel & 1,459 & $100 \%$ & USA & 2,066 & $100 \%$ \\
\hline ESPN2 & 1,098 & $80 \%$ & Syfy & 788 & $100 \%$ \\
\hline ABC Family Channel & 761 & $100 \%$ & CNBC & 656 & $100 \%$ \\
\hline History & 890 & $50 \%$ & Bravo & 650 & $100 \%$ \\
\hline Lifetime Television & 884 & $50 \%$ & $\mathrm{E} !$ & 531 & $100 \%$ \\
\hline$A \& E$ & 879 & $50 \%$ & Comcast RSNs & 1,427 & (c) \\
\hline Total Top Disney & 17,476 & 14,261 & Total Top Comcast & 9,609 & 9,024 \\
\hline Total All Disney & 19,339 & 15,697 & Total All Comcast & 12,498 & 11,255 \\
\hline 21st Century Fox & & & Time Warner Inc. & & \\
\hline FOX & 2,660 & $100 \%$ & The CW & 429 & $50 \%$ \\
\hline FOX News & 1,917 & $100 \%$ & TNT & 2,784 & $100 \%$ \\
\hline FX Network & 1,137 & $100 \%$ & TBS & 1,817 & $100 \%$ \\
\hline FOX Sports RSNs & 3,616 & (a) & $\mathrm{CNN}$ & 1,094 & $100 \%$ \\
\hline Total Top Fox & 9,331 & 8,877 & Cartoon Network & 832 & $100 \%$ \\
\hline Total All Fox & 11,758 & 10,801 & Time Warner RSNs & 545 & (d) \\
\hline Viacom Inc./CBS & & & $\mathrm{HBO} /$ Cinemax & 4,603 & $100 \%$ \\
\hline CBS & 4,241 & $100 \%$ & Total Top Time Warner & 12,103 & 11,903 \\
\hline The CW & 429 & $50 \%$ & Total All Time Warner & 13,496 & 12,787 \\
\hline Nickelodeon & 2,117 & $100 \%$ & Cablevision & & \\
\hline MTV & 1,366 & $100 \%$ & AMC & 877 & $100 \%$ \\
\hline Comedy Central & 780 & $100 \%$ & Cablevision RSNs & 634 & $100 \%$ \\
\hline Spike TV & 651 & $100 \%$ & Total Top Cablevision & 1,511 & 1,511 \\
\hline BET & 580 & $100 \%$ & Total All Cablevision & 2,193 & 2,193 \\
\hline VH1 & 569 & $100 \%$ & Total Vertically Integrated & 28,187 & 26,236 \\
\hline Showtime / TMC / Flix & 1,621 & $100 \%$ & Other/Independent & & \\
\hline EPIX / EPIX Drive-In & 454 & $33 \%$ & Companies & & \\
\hline Total Top Viacom/CBS & 12,809 & 12,290 & Univision & & \\
\hline Total All Viacom/CBS & 14,949 & 14,370 & Univision & 692 & $100 \%$ \\
\hline Liberty Global Inc. & & & UniMás & 175 & $95 \%$ \\
\hline Starz / Encore & 1,385 & $100 \%$ & Scripps & & \\
\hline Discovery Channel & 1,070 & $100 \%$ & HGTV & 876 & $100 \%$ \\
\hline TLC & 593 & $66 \%$ & Food Network & 867 & $69 \%$ \\
\hline Liberty RSNs & 376 & (b) & National Football League & & \\
\hline Total Top Liberty & 3,423 & 2,762 & NFL Network & 1,165 & $100 \%$ \\
\hline Total All Liberty & 4,872 & 4,116 & Total All Other/Inds & & 7,654 \\
\hline Total Big Media & $\mathbf{5 0 , 9 1 8}$ & 44,983 & Total Revenue all Channels & & 86,760 \\
\hline
\end{tabular}

Notes: Reported are the revenue and share owned of the largest US broadcast, cable, Regional Sports, and premium programming networks among major multi-channel owners of such networks in 2013. The left panel of the table reports this information for what are often called "Big Media" companies: Disney, Fox, Viacom/CBS, and Liberty. The top half of the right panel reports this information for content affiliated with large cable operators: Comcast, Time Warner, and Cablevision. The bottom half of the panel reports it for all other (i.e. "independent") owners. Revenue data is from SNL Kagan (2014a). Ownership data was collected by hand from company stock filings and industry sources for the research conducted in Crawford et al. (2015). Within each company, the highest-revenue networks are reported, as well as totals for these networks and for all their networks. Totals in the Ownership Share EOlumn are the same revenue totals weighted by ownership share. Individual RSNs are not reported; see Crawford et al. (2015) for the RSN owned by each listed company and their ownership share. Figure 17 displays graphically the revenue share of each company among the total revenue earned by such networks. 
Table 6: Concentration in the Downstream (Distribution) Market, 1992-2010

\begin{tabular}{|c|c|c|c|c|c|c|}
\hline \multirow[b]{3}{*}{ Rank } & \multicolumn{2}{|l|}{1992} & \multicolumn{2}{|l|}{1997} & \multicolumn{2}{|l|}{2000} \\
\hline & & Market & & Market & & Market \\
\hline & Company & Share & Company & Share & Company & Share \\
\hline 1 & TCI & 27.3 & TCI & 25.5 & AT\&T & 19.1 \\
\hline 2 & TimeWarner & 15.3 & TimeWarner & 16.0 & TimeWarner & 14.9 \\
\hline 3 & Continental & 7.5 & MediaOne & 7.0 & DirecTV & 10.3 \\
\hline 4 & Comcast & 7.1 & Comcast & 5.8 & Comcast & 8.4 \\
\hline 5 & Cox & 4.7 & Cox & 4.4 & Charter & 7.4 \\
\hline 6 & Cablevision & 3.5 & Cablevision & 3.9 & Cox & 7.3 \\
\hline 7 & TimesMirror & 3.3 & DirecTV & 3.6 & Adelphia & 5.9 \\
\hline 8 & Viacom & 3.1 & Primestar & 2.4 & EchoStar (Dish) & 5.1 \\
\hline 9 & Century & 2.5 & Jones & 2.0 & Cablevision & 4.3 \\
\hline \multirow[t]{6}{*}{10} & Cablevision & 2.5 & Century & 1.6 & Insight & 1.2 \\
\hline & Top 4 & 57.2 & Top 4 & 54.3 & Top 4 & 52.7 \\
\hline & Top 8 & 71.8 & Top 8 & 68.6 & Top 8 & 78.4 \\
\hline & Top 25 & - & Top 25 & 84.9 & Top 25 & 89.8 \\
\hline & \multicolumn{2}{|l|}{2004} & \multicolumn{2}{|l|}{2007} & \multicolumn{2}{|l|}{2010} \\
\hline & & Market & & Market & \multirow[b]{2}{*}{ Company } & Market \\
\hline Rank & Company & Share & Company & Share & & Share \\
\hline 1 & Comcast & 23.4 & Comcast & 24.7 & Comcast & 22.6 \\
\hline 2 & DirecTV & 12.1 & DirecTV & 17.2 & DirecTV & 19.0 \\
\hline 3 & TimeWarner & 11.9 & EchoStar (Dish) & 14.1 & EchoStar (Dish) & 14.0 \\
\hline 4 & EchoStar (Dish) & 10.6 & TimeWarner & 13.6 & TimeWarner & 12.3 \\
\hline 5 & Cox & 6.9 & Cox & 5.5 & Cox & 4.9 \\
\hline 6 & Charter & 6.7 & Charter & 5.3 & Charter & 4.5 \\
\hline 7 & Adelphia & 5.9 & Cablevision & 3.2 & Verizon FiOS & 3.5 \\
\hline 8 & Cablevision & 3.2 & Bright & 2.4 & Cablevision & 3.3 \\
\hline 9 & Bright & 2.4 & Suddenlink & 1.3 & AT\&T Uverse & 3.0 \\
\hline 10 & Mediacom & 1.7 & Mediacom & 1.3 & Bright & 2.2 \\
\hline & Top 4 & 58.0 & Top4 & 69.6 & Top4 & 68.0 \\
\hline & Top 8 & 80.7 & Top8 & 86.0 & Top8 & 84.0 \\
\hline & Top 25 & 90.4 & Top 25 & - & Top 25 & 一- \\
\hline
\end{tabular}

Notes: Reported are the market shares of the largest distributors of pay-television services across a selection of years between 1992 and 2010 taken from annual FCC reports on the status of competition in the pay-television market. Also reported is the sum of the market shares for the largest 4, 8, and 25 such distributors. Source: FCC (1997), FCC (1998), FCC (2001), FCC (2005a), FCC (2012c) 

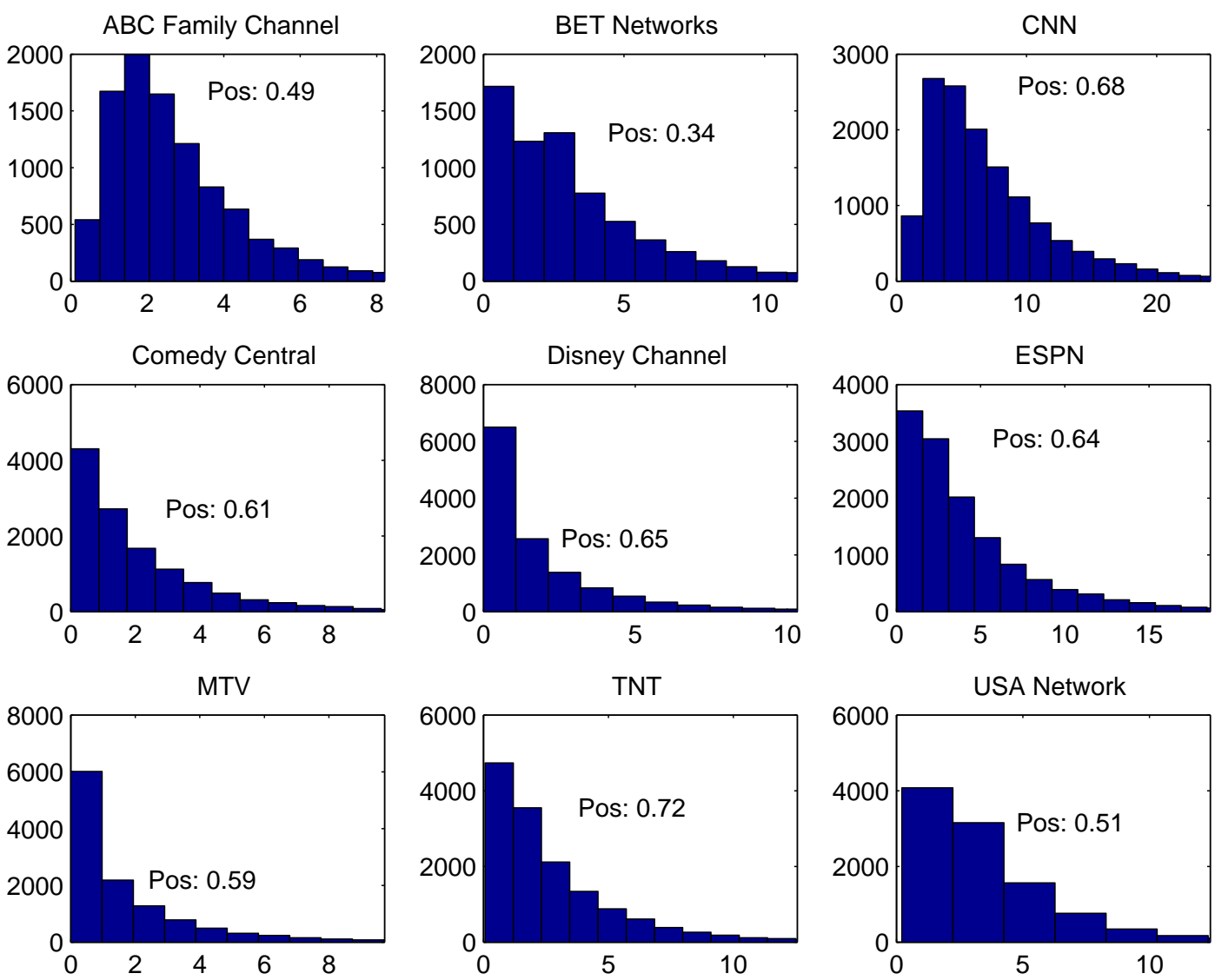

Figure 18: Estimated WTP for a Subset of Television Channels

Notes: Reported, from Crawford and Yurukoglu (2012), is the estimated share of 20,000 simulated households that value each of nine large pay-television networks positively ("Pos")and the estimated distribution of their willingness-to-pay (WTP) for each network. In each figure, the y-axis reports households and the x-axis reports WTP in 2000 dollars. 
Figure 19: Vertical Integration between Channels and Distributors, 2012

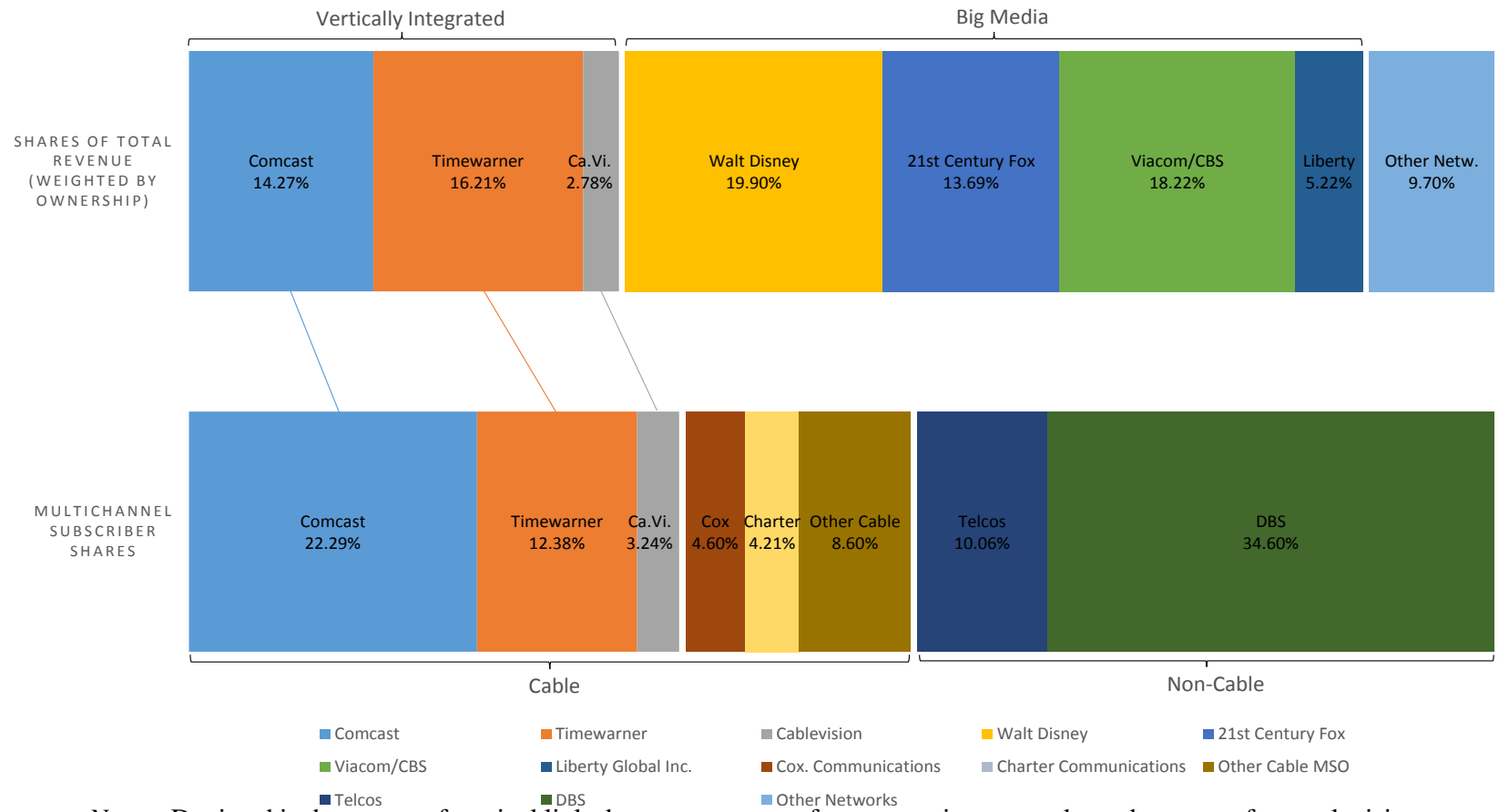

Notes: Depicted is the nature of vertical links between owners of programming networks and owners of pay-television distribution platforms. Revenue and ownership shares for the programming market are as described in the notes to Table 5 above. Shares in the distribution market are subscriber shares drawn from SNL Kagan (2014a). DBS stands for Direct Broadcast Satellite and is the sum of the subscriber shares for DirecTV and Dish Network. Ownership data was collected by hand from company stock filings and industry sources for the research conducted in Crawford et al. (2015). 
Figure 20: OTT Share of Global Pay TV Revenues, 2008-2017

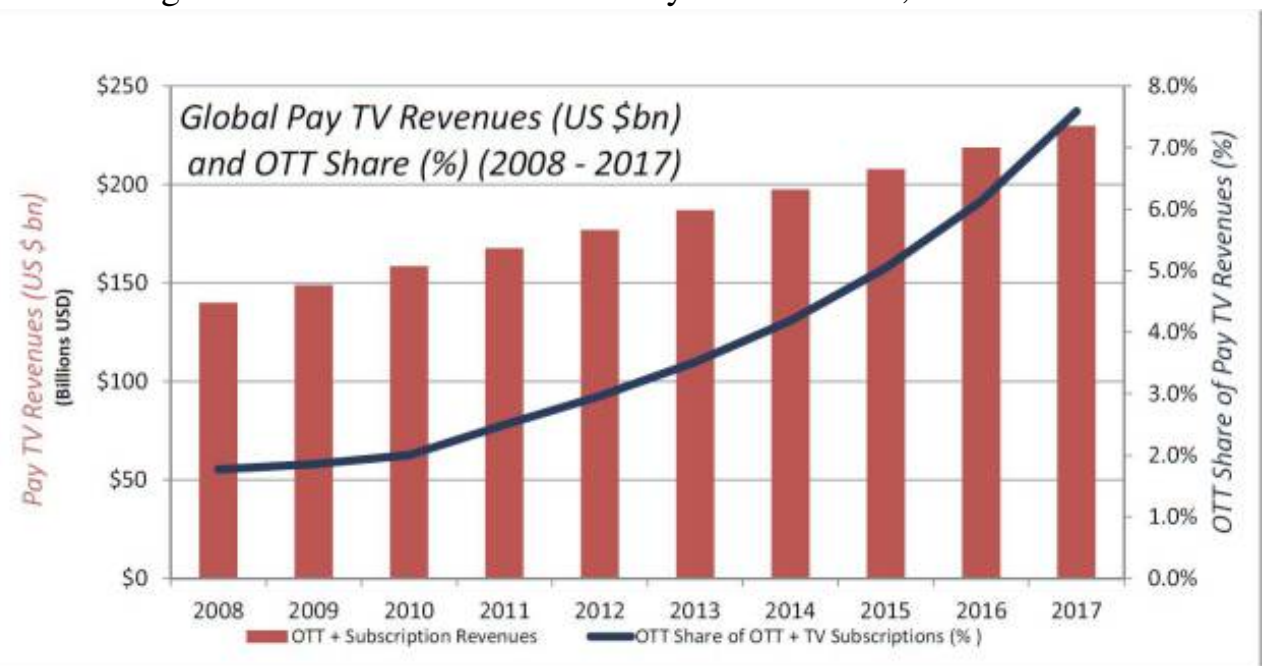

Notes: Depicted is estimated world-wide pay-television plus over-the-top Internet television (OTT) revenue and the share of this revenue accruing to OTT services.

Source: PriceWaterhouseCoopers (2013) 


\section{References}

Adams, William James and Janet L. Yellen, "Commodity Bundling and the Burden of Monopoly," Quarterly Journal of Economics, 1976, 90 (3), 475-98.

Analysys Mason and BrandScience, "An econometric analysis of the TV advertising market: final report," Technical Report, Office of Communications 2010. Published May 2010. Available at http://stakeholders.ofcom.org.uk/market-data-research/other/tv-research/arr/.

Anderson, Chris, The Long Tail: Why the Future of Business is Selling Less of More, Hyperion, 2006.

Anderson, S. and S. Coate, "Market Provision of Broadcasting: A Welfare Analysis," Review of Economic Studies, October 2005, 72, 947-972.

Armstrong, Mark, "Competition in the pay-TV market," Journal of the Japanese and International Economies, 1999, 13 (4), 257-280.

, "Price Discrimination by a Many-Product Firm," Review of Economic Studies, 1999, 66 (1), 151-168. , “Public Service Broadcasting,” Fiscal Studies, 2005, 26 (3), 281-299.

, "Competition in two-sided markets," The RAND Journal of Economics, 2006, 37 (3), 668-691.

and Helen Weeds, "Public service broadcasting in the digital world," in "The Economic Regulation of Broadcasting Markets," Cambridge University Press, 2007.

and John Vickers, “Competitive Price Discrimination,” RAND Journal of Economics, 2001, 32 (4), 579-605.

Baker, Jonathan B, Mark Bykowsky, Patrick DeGraba, Paul LaFontaine, Eric Ralph, and William Sharkey, "The Year in Economics at the FCC, 2010-11: Protecting Competition Online," Review of Industrial Organization, 2011, 39 (4), 297-309.

Bakos, Yannis and Erik Brynjolfsson, "Bundling Information Goods: Pricing, Profits, and Efficiency," Management Science, 1999, 45 (2), 1613-1630.

Beebe, J., "Institutional Structure and Program Choices in Television Markets," Quarterly Journal of Economics, 1977, 91, 15-37. 
Besanko, D., S. Donnenfeld, and L. J. White, "Monopoly and Quality Distortion: Effects and Remedies," Quarterly Journal of Economics, 1987, 102 (4), 743-67.

$\ldots$ _ _ a a _ _ _ "The Multiproduct Firm, Quality Choice, and Regulation,” Journal of Industrial Economics, 1988, 36 (4), 411-429.

Bonanno, G. and J. Vickers, “Vertical Separation,” Journal of Industrial Economics, 1988, 36, 257-266.

Bresnahan, Timothy F and Jonathan D Levin, "Vertical Integration and Market Structure,” 2012. working paper, National Bureau of Economic Research.

Byzalov, Dmitri, “Unbundling Cable Television: An Empirical Investigation,” 2010. Working Paper, Temple University.

Cablevision Systems Corp, "Cablevision Systems Corporation and CSC Holdings, LLC, plaintiffs, against Viacom International Inc. and Black Entertainment Television LLC, defendants: Complaint,” Technical Report, United States District Court, Southern District of New York 2013. Filed March 7, 2013.

Cauley, Leslie, “FCC puts 'A La Carte' on the Menu,” USA Today, 2007. September 11, 2007.

Chipty, T., "Horizontal Integration for Bargaining Power: Evidence from the Cable Television Industry," Journal of Economics and Management Strategy, 1995, 4 (2), 375-97.

Chipty, Tasneem, "Vertical Integration, Market Foreclosure, and Consumer Welfare in the Cable Television Industry," American Economic Review, 2001, 91 (3), 428-453.

and Christopher M. Snyder, "The role of Firm Size in Bilateral Bargaining: A Study of the Cable Television Industry," Review of Economics and Statistics, 1999, 31 (2), 326-340.

Chu, Chenghuan Sean, "The Effects of Satellite Entry on Cable Television Prices and Product Quality," Rand Journal of Economics, 2010, 41 (4), 730-764.

, Phillip Leslie, and Alan Sorensen, "Bundle-size Pricing as an Approximation to Mixed Bundling," American Economic Review, 2011, 101 (1).

Collard-Wexler, Allan, Gautam Gowrisankaran, and Robin S. Lee, "An Alternating Offers Representation of the Nash-in-Nash Bargaining Solution,” 2012. mimeo., New York University, Stern School of Business. 
Communications Daily, "NARUC Panel Urges Ending Unfair Content Pricing, Tiering, Tying," Сотmиnications Daily, 2011. July 20, 2011.

CPB, "Alternative Sources of Funding for Public Broadcasting Stations," Technical Report, Corporation for Public Broadcasting 2012. Available at http://www.cpb.org/aboutcpb/Alternative_ Sources_of_Funding_for_Public_Broadcasting_Stations.pdf.

Crandall, R. and H. Furchtgott-Roth, Cable TV: Regulation or Competition?, Washington, DC: Brookings Institution Press, 1996.

Crawford, Gregory S., “The Impact of the 1992 Cable Act on Household Demand and Welfare," RAND Journal of Economics, Autumn 2000, 31 (3), 422-449.

_ , "Television Station Ownership Structure and the Quantity and Quality of Television Programming," Technical Report, Federal Communications Commission July 2007. Available at http://www.fcc.gov/mb/mbpapers.html.

, "The Discriminatory Incentives to Bundle in the Cable Television Industry," Quantitative Marketing and Economics, 2008, 6 (1), 41-78.

, "Cable Regulation in the Internet Era," in N. Rose, ed., Economic Regulation and Its Reform: What have we Learned?, University of Chicago Press, 2013, chapter 6. forthcoming, chapters available online at http://www.nber.org/books_in_progress/econ-reg/.

and Ali Yurukoglu, "The Welfare Effects of Bundling in Multichannel Television Markets," American Economic Review, 2012, 102 (2), 643-685.

and Joseph Cullen, "Bundling, Product Choice, and Efficiency: Should Cable Television Networks be Offered À La Carte?," Information Economics and Policy, 2007, 19 (3-4), 379-404.

and Matthew Shum, "Monopoly Quality Degradation in the Cable Television Industry," The Journal of Law and Economics, 2007, 50 (1), 181-219.

, Evan Kwerel, and Jonathan Levy, "Economics at the Federal Communications Commission, 200708," Review of Industrial Organization, 2008, 33, 187-210.

, Jeremy Smith, and Paul Sturgeon, "The (inverse) demand for advertising in the UK: Should there be more advertising on television?,” June 2012. Working Paper, University of Warwick. 
, Olexsandr Shcherbakov, and Matthew Shum, "The Welfare Effects of Endogenous Quality Choice: Evidence from Cable Television Markets,” 2012. Working paper, University of Warwick.

_ Robin Lee, Michael Whinston, and Ali Yurukoglu, "The Welfare Effects of Vertical Integration in Multichannel Television Markets,” 2015. Work in progress, University of Zurich.

d'Aspremont, C., J. Gabszewicz, and J.-F. Thisse, "On Hotelling's Stability in Competition," Econometrica, 1979, 47, 1145-1150.

Farrell, Joseph and Philip J Weiser, "Modularity, Vertical Integration, and Open Access Policies: Towards a Convergence of Antitrust and Regulation in the Internt Age," Harv. JL \& Tech., 2003, 17, 85.

FCC, "Third Annual Report on the Status of Competition in the Market for the Delivery of Video Programming (1996 Report)," Technical Report, Federal Communications Commission 1997. CS Docket No 96-133, Released January 2, 1997.

, "Fourth Annual Report on the Status of Competition in the Market for the Delivery of Video Programming (1997 Report)," Technical Report, Federal Communications Commission 1998. FCC 97-423, Released January 13, 1998.

, "Seventh Annual Report on the Status of Competition in the Market for the Delivery of Video Programming (2000 Report)," Technical Report, Federal Communications Commission 2001. FCC 01-1, Released January 8, 2001.

, "Memorandum Opinion and Order in the matter of Applications for Consent to the Transfer of Control of Licenses from Comcast Corporation and AT\&T Corp., Transferors, to AT\&T Comcast Corporation, Transferee," Technical Report, Federal Communications Commission 2002. MB Docket No. 02-70, FCC 02-310.

, "Eleventh Annual Report on the Status of Competition in the Market for the Delivery of Video Programming (2004 Report)," Technical Report, Federal Communications Commission 2005. FCC 05-13, Released February 4, 2005.

, “Second Further Notice of Proposed Rulemaking,” Technical Report, Federal Communications Commission 2005. MM Docket No. 92-264, FCC 05-96. 
_ , "The Public and Broadcasting," Technical Report, Federal Communications Commission 2008. DA08-940A2. Released July 2008. Available at http://www.fcc.gov/guides/public-and-broadcasting-july2008.

, “2006-2008 Report on Cable Industry Prices,” Technical Report, Federal Communications Commission 2009. FCC 09-53, Released January 16, 2009.

__ , “Connecting America: The National Broadband Plan,” Technical Report, Federal Communications Commission 2010. Released March 16, 2010. Available at http://www.broadband.gov/download-plan/.

— , "Report and Order In the Matter of Preserving the Open Internet Broadband Industry Practices," Technical Report, Federal Communications Commission 2010. FCC 10-201.

_ _ "The Information Needs of Communities," Technical Report, Federal Communications Commission 2011. Available at http://www.fcc.gov/info-needs-communities.

, "Memorandum Opinion and Order in the matter of Applications of Comcast Corporation, General Electric Company and NBC Universal, Inc. For Consent to Assign Licenses and Transfer Control of Licensees,” Technical Report, Federal Communications Commission 2011. MB Docket No. 10-56.

_ , "Memorandum Opinion and Order in the matter of Applications of Comcast Corporation, General Electric Company and NBC Universal, Inc. For Consent to Assign Licenses and Transfer Control of Licensees," Technical Report, Federal Communications Commission 2011. FCC 11-4, released January 20, 2011.

_ _ “2011 Report on Cable Industry Prices,” Technical Report, Federal Communications Commission 2012. DA 12-1322, Released August 13, 2012.

, "First Report and Order,” Technical Report 2012. FCC 10-17, Released January 20, 2012.

, "Fourteenth Annual Assessment on the Status of Competition in the Market for the Delivery of Video Programming (2007-2010 Report)," Technical Report, Federal Communications Commission 2012. FCC 12-81, Released July 20, 2012.

, "Report and Order in MB Docket Nos. 12-68, 07-18, 05-192; Further Notice of Proposed Rulemaking in MB Docket No. 12-68; Order on Reconsideration in MB Docket No. 07-29,” Technical Report 2012. FCC 12-123, released October 5, 2012. 
"Broadcast Radio AM and FM Application Status Lists," Technical Report, Federal Communications Commission April 2013. Available at http://www.fcc.gov/encyclopedia/broadcast-radio-am-and-fmapplication-status-lists, accessed December 9, 2013.

, "Fifteenth Annual Assessment on the Status of Competition in the Market for the Delivery of Video Programming (2011-2012 Report)," Technical Report, Federal Communications Commission 2013. FCC 13-99, Released July 22, 2013.

, "Report and Order on Remand, Declaratory Ruling, and Order In the matter of Protecting and Promoting the Open Internet,” Technical Report, Federal Communications Commission 2015. FCC 15-24, released March 12, 2015.

Filistrucchi, Lapo, Luigi Luini, and Andrea Mangani, "Regulating one side of a two-sided market: The French advertising ban on prime-time state television," 2010. Working Paper, Department of Economics, CentER and TILEC, Tilburg University.

Ford, G. and J. Jackson, "Horizontal Concentration and Vertical Integration in the Cable Television Industry," Review of Industrial Organization, 1997, 12 (4), 501-518.

Gabszewicz, Jean J, Dider Laussel, and Nathalie Sonnac, "Press advertising and the ascent of the ŚPensée UniqueŠ,” European Economic Review, 2001, 45 (4), 641-651.

Gal-Or, E., “Duopolistic Vertical Restraints,” European Economic Review, 1991, 35, 1237-1253.

Gentzkow, M. and J. Shapiro, "Preschool Television Viewing and Adolescent Test Scores: Historical Evidence from the Coleman Study," 2007. forthcoming, Quarterly Journal of Economics.

Gentzkow, Matthew, “Television and Voter Turnout," Quarterly Journal of Economics, 2006, 121 (3), 931-972.

Godes, David, Elie Ofek, and Miklos Sarvary, "Content vs. advertising: The impact of competition on media firm strategy," Marketing Science, 2009, 28 (1), 20-35.

Goolsbee, Austan and Amil Petrin, "Consumer Gains from Direct Broadcast Satellites and the Competition with Cable TV," Econometrica, 2004, 72 (2), 351-81.

Haider, Anser, "Research Roundup, M\&C edition: Internet data usage climbs, Netflix dominates North American fixed networks," Technical Report, SNL Financial 2012. November 11, 2012. 
Hamilton, James T, Channeling violence: The economic market for violent television programming, Princeton University Press, 2000.

Harbord, David and Marco Ottaviani, "Contracts and Competition in the Pay TV Market," 2001. working paper, University College London.

Hazlett, T. and M. Spitzer, Public Policy Towards Cable Television: The Economics of Rate Controls, MIT Press, 1997.

Ho, Katherine, "Insurer-Provider Networks in the Medical Care Market," American Economic Review, 2009, $99(1), 393-430$.

Horn, Hendrick and Asher Wolinsky, "Bilateral Monopoly and Incentives for Merger," The RAND Journal of Economics, 1988, 19, 408-419.

Hurkens, Sjaak, Doh-Shin Jeon, and Domenico Menicucci, "Dominance and Competitive Bundling," 2013. Working paper, Toulouse School of Economics.

Inderst, Roman and Joao Montez, "Buyer Power and Dependency in a Model of Negotiations," 2015. Working paper, London Business School.

ITU, "Guidelines for the Transition from analogue to digital broadcasting," Technical Report, International Telecommunications Union 2012. August 2012.

Jensen, Robert and Emily Oster, "The power of TV: Cable television and women's status in India," The Quarterly Journal of Economics, 2009, 124 (3), 1057-1094.

Lee, Daeho and Yong-Hwa Kim, "Empirical evidence of network neutrality: The incentives for discrimination,", Information Economics and Policy, 2014, 29, 1-9.

Lee, Robin S and Tim Wu, "Subsidizing creativity through network design: Zero-pricing and net neutrality," The Journal of Economic Perspectives, 2009, 23 (3), 61-76.

Liu, Yong, Daniel S. Putler, and Charles B. Weinberg, "Is Having More Channels Really Better? A Model of Competition Among Commercial Television Broadcasters," Marketing Science, 2004, 23 (1), 120-133.

Madden, Paul and Mario Pezzino, "Sports league quality, broadcaster TV rights bids and wholesale regulation of sports channels," 2013. Working paper, University of Manchester. 
Martin, Gregory J. and A. Yurukoglu, "Bias in Cable News: Real Effects and Polarization,” 2014. mimeo, Stanford University.

Mayo, J. and Y. Otsuka, "Demand, Pricing, and Regulation: Evidence from the Cable TV Industry," Rand Journal of Economics, 1991, 22 (3), 396-410.

Muthoo, Abhinay, Bargaining Theory with Applications, Cambridge: Cambridge University Press, 1999.

Nalebuff, B., "Bundling as an Entry Barrier," Quarterly Journal of Economics, 2004, 119 (1), 159-187.

Nash, John F., “The Bargaining Problem,” Econometrica, 1950, 18 (2), 155-162.

Nurski, Laura, "Net neutrality and online innovation: An empirical study of the UK," 2014. Working paper, University of Leuven.

Ofcom, “Ofcom review of Public Service Broadcasting Phase 1: Is television special?," Technical Report, UK Office of Communications 2004. Available at http://stakeholders.ofcom.org.uk/consultations/psb/.

—, "Pay TV phase three document: Proposed remedies," Technical Report, Office of Communications 2009. Published 26 June 2009. Available at http://stakeholders.ofcom.org.uk/consultations/third_paytv/.

_, "Wholesale must-offer remedies: international examples," Technical Report, Office of Communications 2009. Published 26 June 2009. Available at http://stakeholders.ofcom.org.uk/consultations/third_paytv/.

, "Pay TV Statemnt," Technical Report, Office of Communications 2010. Published 31 March 2010. Available at http://stakeholders.ofcom.org.uk/consultations/third_paytv/.

, "Premium Pay TV Movies," Technical Report, Office of Communications 2010. Published August 4, 2010. Available at http://stakeholders.ofcom.org.uk/consultations/movies_reference/statement/. , “International Communications Market Report 2012,” Technical Report, Office of Communications 2012. Published December 13, 2012. Available at http://stakeholders.ofcom.org.uk/market-dataresearch/market-data/communications-market-reports/.

Ordover, J., G. Saloner, and S. Salop, "Equilibrium Vertical Foreclosure," American Economic Review, 1990, 80, 127-142.

Owen, B. and S. Wildman, Video Economics, Harvard University Press, 1992. 
Peitz, M. and T. Valletti, "Content and Advertising in the Media: Pay-tv versus free-to-air," International Journal of Industrial Organization, 2008, 26 (4), 949-965.

Peitz, Martin, “Bundling may blockade entry," International Journal of Industrial Organization, 2008, 26 (1), 41-58.

Prat, Andrea and David Strömberg, "Commercial Television and Voter Information,” 2006. Working paper, LSE.

and __ , "The Political Economy of Mass Media," 2011. Working paper, LSE.

PriceWaterhouseCoopers, "Global entertainment and media outlook," Technical Report, PriceWaterhouseCoopers June 2012.

__ , "Global entertainment and media outlook," Technical Report, PriceWaterhouseCoopers June 2013.

Raskovich, Alexander, "Pivotal Buyers and Bargaining Position," Journal of Industrial Economics, 2003, $51(4), 405-426$.

Rennhoff, Adam D. and Konstantinos Serfes, "Estimating the Effects of A La Carte Pricing: The Case of Cable Television,” 2008. mimeo, Drexel University.

and __ , "Estimating the Effects of a la Carte Pricing: The Case of Cable Television," SSRN eLibrary, 2008.

and __ , "The Role of Upstream-Downstream Competition on Bundling Decisions: Should Regulators Force Firms to Unbundle?," Journal of Economics and Management Strategy, 2009, 18 (2), $547-588$.

Rey, P. and J. Tirole, "A Primer on Foreclosure," in M. Armstrong and R. Porter, eds., Handbook of Industrial Organization, Vol. 3, Amsterdam: North-Holland, 2007, chapter 33.

Riordan, M., "On Delegating Price Authority to a Regulated Firm," Rand Journal of Economics, 1984, 15 (1), 108-115.

_ _ "Competitive Effects of Vertical Integration," in P. Buccirossi, ed., Handbook of Antitrust Economics, MIT Press, 2008.

Robinson, Frances, "Italian EU Presidency Puts Net Neutrality On Hold," Wall Street Journal, 2014. November 25, 2014. 
Rubinfeld, Daniel L and Hal J Singer, "Vertical foreclosure in broadband access?," The Journal of Industrial Economics, 2001, 49 (3), 299-318.

Rubinovitz, R., "Market Power and Price Increases for Basic Cable Service Since Deregulation,” Rand Journal of Economics, 1993, 24 (1), 1-18.

Rubinstein, Ariel, "Perfect Equilibrium in a Bargaining Model," Econometrica, 1982, 50 (1), 97-109.

Salop, S. and D. Scheffman, “Raising Rivals' Costs,” American Economic Review, 1983, 74 (2), 267-271.

Scannell, Paddy, Public service broadcasting: the history of a concept, Routledge London, 1990.

Shiller, B. and J. Waldfogel, "Music for a Song: An Empirical Look at Uniform Song Pricing and Its Alternatives," Journal of Industrial Economics, December 2011.

SNL Kagan, “OTT Entities in 35 Global Markets,” Technical Report, SNL Financial 2012. November 8, 2012.

"Media and Communications Database," 2014. http://www.snl.com/Sectors/Media/ Default.aspx (licensed in 2014 from Kagan World Media).

, “Neflix rocked by Net Neutrality ruling,” Technical Report, SNL Financial 2014. January 17, 2014.

Steiner, P., "Program Patterns and Preferences and the Workability of Competition in Radio Broadcasting," Quarterly Journal of Economics, 1952, 66 (2), 194-223.

Stennek, Johan, "Exclusive quality Ü Why exclusive distribution may benefit the TV-viewers," Information Economics and Policy, 2014, 26, 42-57.

Stigler, George J., “A Note on Block Booking," in G. Stigler, ed., The Organization of Industry, Richard D. Irwin, 1968.

UK Competition Commission, "Movies on pay TV market investigation," Technical Report, UK Competition Commission 2012. Published August 2, 2012. Available at http://www.competitioncommission.org.uk/our-work/directory-of-all-inquiries/movies-on-pay-tv-market-investigation.

Waterman, D. H. and A. A. Weiss, "The Effects of Vertical Integration between Cable Television Systems and Pay Cable Networks," Journal of Econometrics, 1996, 72 (1-2), 357-95. and , Vertical Integration in Cable Television, MIT Press and AEI Press, 1997. 
Weeds, Helen, “TV Wars: Exclusive Content and Platform Competition in Pay TV,” Economic Journal, 2015.

Whinston, M., “Tying, Foreclosure, and Exclusion,” American Economic Review, 1990, 80 (4), 837-859.

Wilbur, Kenneth C., "An Two-Sided, Empirical Model of Television Advertising and Viewing Markets," Marketing Science, 2008, 27 (3), 356-378.

Willems, Michiel, “Cable's flirtations with telcos turn into full-blown love affair,” SNL Blogs, 2014. March $12,2014$.

Williamson, O., "Franchise Bidding for Natural Monopolies: In General and with respect to CATV," Bell Journal of Economics, 1976, 7 (1), 73-104.

Zupan, M. A., “Cable Franchise Renewals : Do Incumbent Firms Behave Opportunistically,” Rand Journal of Economics, 1989, 20 (4), 473-482.

, "The Efficacy of Franchise Bidding Schemes in the Case of Cable Television : Some Systematic Evidence," Journal of Law and Economics, 1989, 32 (1), 401-36. 